\title{
Bushmeat and human health: Assessing the Evidence in tropical and sub-tropical forests
}

Nathalie Van Vliet ${ }^{1 *}$, Jessica Moreno ${ }^{2}$, Juanita Gómez ${ }^{2}$, Wen Zhou ${ }^{1}$, John Emmanuel Fa ${ }^{1}$, Christopher Golden ${ }^{3}$, Rômulo Romeu Nóbrega Alves ${ }^{4}$, Robert Nasi ${ }^{1}$

\begin{abstract}
The importance of bushmeat as source of food and medicine for forest peoples calls for an appropriate benefit/risk analysis in terms of human health. In this systematic review, we compiled information on the linkages between bushmeat and health, with a particular focus on the nutritional content, the zoo-therapeutic uses and the zoonotic pool of bushmeat species in tropical and sub-tropical forest regions. Despite the scarcity of data on the nutritional content of most common bushmeat species, the available studies demonstrate that bushmeat is an important source of fats, micro and macro-nutrients and has a diversity of medicinal uses. However, bushmeat may have detrimental health impacts where hunting, transportation, handling and cooking practices do not follow food safety practices. There is evidence that some bushmeat carcasses may be contaminated by toxic metals or by polycyclic aromatic hydrocarbons. Moreover, several pathogens carried by bushmeat are found to be zoonotic and potentially transmissible to humans through consumption or through exposure to body fluids and feces. We stress the need for more in-depth studies on the complex links between bushmeat and human health. The development of innovative handling, conservation and cooking practices, adapted to each socio-cultural context, should help reduce the negative impacts of bushmeat consumption on human health.
\end{abstract}

Keywords: Ethnozoology, systematic review, bushmeat, nutrient, zoonosis, zootherapy, health

\footnotetext{
${ }^{1}$ Center for International Forestry Research. Jalan CIFOR Situ Gede, Sindang Barang, Bogor (Barat) 16115, Indonesia.

${ }^{2}$ Fundación Science International. Calle 28 No. 13a-24. Bogotá, Colombia.

${ }^{3}$ Harvard School of Public Health. 677 Huntington Ave, Boston, MA 02115, EE. UU.

${ }^{4}$ Departamento de Biologia, Universidade Estadual da Paraíba. R. Baraúnas, 351 - Universitário, Campina Grande - PB, 58429-500, Brasil.

* Corresponding author. \E-mail address: vanvlietnathalie@yahoo.com
} 


\section{INTRODUCTION}

There is growing evidence that points to the importance of wildlife as a source of nutrition, medicine and spiritual values in many human cultures in tropical and subtropical areas worldwide (Scoones et al. 1992; Nasi et al. 2008). The meat of wild animals in particular, commonly referred to as bushmeat, has formed a part of the staple diet of forest dwelling peoples for millennia (Elliott et al. 2002) and remains a primary source of animal protein, micro-nutrients and fat (Wilkie et al. 2005; Nasi et al. 2011, Siren and Machoa 2008; Golden et al. 2011; Mori et al. 2015, Alves et al. 2016). Bushmeat is also a significant source of revenue for many forest families (Milner-Gulland et al., 2003). Consumers often consider bushmeat a wholesome, safe alternative to commercially produced meat on sale at grocery stores. In some regions, it is preferred to farm-raised meats for its taste or based on the perception that industrial meats contain chemicals and additives (van Vliet and Mbazza 2011). Moreover, bushmeat also plays a special role in the cultural and spiritual identity of indigenous peoples (Siren 2012). Cawthorn and Hoffman (2015) have provided an extensive review of the nexus between bushmeat and livelihoods, emphasizing the contributions of bushmeat to food security, nutrition and well-being. In some communities, human ailments are treated with products derived from animals, also known as zootherapy (Alves et al. 2013a; Begossi and Braga 1992; Johns 1996; Martinez 2013). Such animal-based preparations constitute a plethora of medicinal solutions employed by numerous cultures since ancient times, and are still being used in different parts of the world as primary or complementary treatments (Alves and Rosa 2013).

However, it is also well established that all sorts of animal-derived foods and remedies are capable of producing adverse reactions (Alves et al. 2013b) and the consumption of animal products as food or medicine also facilitates the transmission of serious and widespread zoonoses. Thus, it is essential that traditional foods and drug therapies be submitted to an appropriate benefit/risk analysis. Increased research efforts in the last decade, further spurred by recent zoonotic disease epidemics (Kurpiers et al. 2016), have focused attention on the potential for bushmeat to act as a reservoir for pathogen transmission and spread into at-risk human populations.

To date, the role of wild meats in the provision of human nutrition and remedies and the emergence of human diseases presents something of a paradox and requires an assessment of its costs and benefits: "is bushmeat healthy or the opposite?". However, because nutritionists, ethno-zoologists and epidemiologists often work in isolation from one another, there is no compiled evidence of the links between bushmeat and health that can assist policy makers in setting benchmarks of what is currently known and further allow researchers to better assess the importance of the resource. To respond to this need, we systematically reviewed all available information on: 1) the nutrient composition of bushmeat 2) its use in curative or preventive medicine and 3) the zoonotic pool present in bushmeat species.

\section{METHODOLOGY}

Our review provides a posteriori comparison of published case studies dated up to November 2016 that illustrate the links between bushmeat and health. We performed a systematic search on Google Scholar, Web of Science and CAB Direct (Figure 1). 


\section{METHODOLOGY}

Search using different word

combinations in English,

Spanish, French and Portuguese

in Google Scholar, CAB and WOK

$\Rightarrow \uparrow \checkmark$ Exclude duplicates

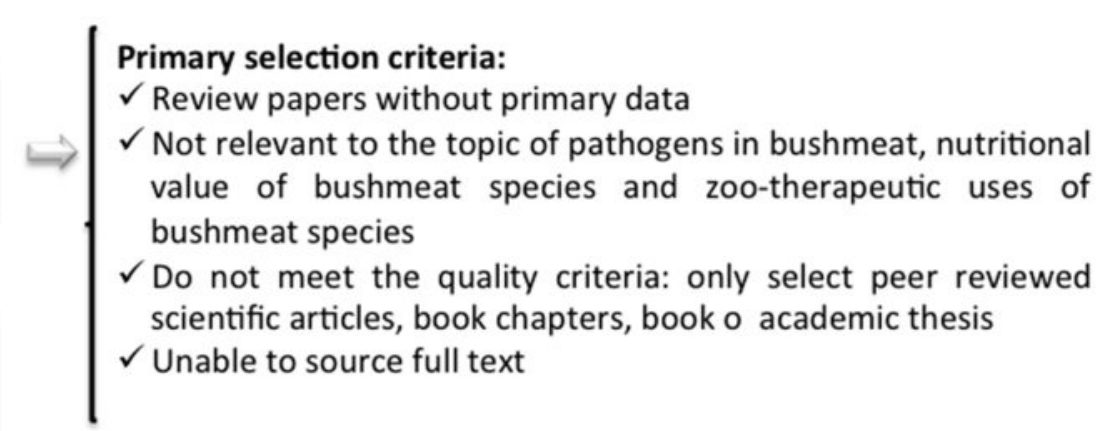

Secondary selection criteria:

$\checkmark$ Do not use the definition of bushmeat as stated in the methodology

Relevant studies for data extraction and synthesis $\checkmark$ Do not correspond to tropical and subtropical forests

$\checkmark$ Do not present zoo-therapeutic uses of parts consumed by humans

$\checkmark$ Do not present pathogens transmitted to humans through handling or consumption

Figure 1. Methodology used for the systematic review process

In Google Scholar we searched using 40 combinations of words in English, Spanish, Portuguese and French (Table1). The search yielded 13827 results, excluding duplicates.

In the Web of Science database, we used the following search string, with language limits for articles in English, Spanish, Portuguese, and French, and retrieved 1105 additional results: ("game meat" OR "wild game" OR bushmeat OR "wild meat") AND (nutri* OR protein* OR calori* OR diet* OR consum* OR zoono* OR pathogen* OR disease* $^{*}$ OR illness* OR infectio* OR medicin* OR therap* OR health OR treatment* OR "traditional medicine*" OR "folk medicine*" OR "alternative medicine*").

In $C A B$ Direct, we used the following search string to yield 122 additional results ("game meat" OR "wild game" OR "bush meat" OR bushmeat OR "wild meat") AND (nutri* OR "nutritive value" OR protein* OR calori* OR diet* OR consum* OR zoono* OR pathogen* OR disease* OR illness* OR infectio* OR medicin* OR "medicinal properties" OR therap* OR health OR treatment* OR "traditional medicine*" OR "folk medicine*" OR "alternative medicine*").

The search strings were developed and validated among the authors, which together constitute a group of experts on bushmeat, zootherapy, nutrition and health.

The references were first screened by title and abstract according to the primary inclusion criteria below:

1. ONLY studies for which we were able to source the full text. Sixteen studies were eliminated because their PDFs could not be found. 
Table 1. Results of the google scholar search using several key word combinations in Spanish, Portuguese, French and English

\begin{tabular}{|c|c|c|}
\hline Combinations for search in english & Results & $\begin{array}{l}\text { Number of selected } \\
\text { papers after } 1 \text { st and } \\
2 \text { nd selection criteria }\end{array}$ \\
\hline Bushmeat + health + nutrition & 4.140 & 8 \\
\hline Bushmeat + health + zoonosis & 2.140 & 19 \\
\hline Bushmeat + health + zootherapy & 44 & 0 \\
\hline Bushmeat + health + "traditional medicine" & 1090 & 9 \\
\hline Bushmeat + health + "medicinal animals" & 38 & 4 \\
\hline "Wild meat" + health + nutrition & 1.530 & 1 \\
\hline "Wild meat" + health + zoonosis & 221 & 0 \\
\hline "Wild meat" + health + zootherapy & 12 & 0 \\
\hline "Wild meat" + health + "traditional medicine" & 326 & 0 \\
\hline "Wild meat" + health + "medicinal animals" & 17 & 0 \\
\hline Combinations for search in spanish & Results & Total references \\
\hline "came de monte" + salud + nutrición & 204 & 2 \\
\hline "came de monte" + salud + zoonosis & 20 & 0 \\
\hline "came de monte" + salud + zooterapia & 1 & 2 \\
\hline "came de monte" + salud + "medicina tradicional" & 153 & 1 \\
\hline "came de monte" + salud + "animales medicinales" & 0 & 0 \\
\hline "came de animales silvestres" + salud + nutrición & 81 & 0 \\
\hline "came de animales silvestres" + salud + zoonosis & 34 & 0 \\
\hline "came de animales silvestres" + salud + zooterapia & 1 & 0 \\
\hline $\begin{array}{l}\text { "came de animales silvestres" + salud + "medicina } \\
\text { tradicional" }\end{array}$ & 47 & 0 \\
\hline $\begin{array}{l}\text { "came de animales silvestres" + salud + "animales } \\
\text { tradicionales" }\end{array}$ & 0 & 0 \\
\hline Combinations for search in portuguese & Results & Total references \\
\hline "came de caça" + saúde + nutrição & 299 & 1 \\
\hline "came de caça" + saúde + zoonose & 46 & 2 \\
\hline "came de caça" + saúde + zoo terapia & 9 & 1 \\
\hline "came de caça" + saúde + "medicina tradicional" & 65 & 0 \\
\hline "came de caça" + saúde + "animais medicinais" & 8 & 0 \\
\hline "came de animais selvagens" + saúde + nutrição & 12 & 0 \\
\hline "came de animais selvagens" + saúde + zoonose & 10 & 0 \\
\hline "came de animais selvagens" + saúde + zoo terapia & 3 & 0 \\
\hline $\begin{array}{l}\text { "came de animais selvagens" + saúde + "medicina } \\
\text { tradicional" }\end{array}$ & 1 & 0 \\
\hline $\begin{array}{l}\text { "came de animais selvagens" + saúde + "animais } \\
\text { medicinais" }\end{array}$ & 9 & 0 \\
\hline Combinations for search in french & Results & Total references \\
\hline "viande de brousse" + santé + nutrition & 158 & 1 \\
\hline "viande de brousse" + santé + zoonose & 84 & 2 \\
\hline "viande de brousse" + santé + zoothérapie & 1 & 0 \\
\hline "viande de brousse" + santé + "médecine traditionelle" & 72 & 0 \\
\hline "viande de brousse" + santé + "animaux médicinaux" & 0 & 0 \\
\hline Gibier + santé + nutrition & 2150 & 0 \\
\hline Gibier + santé + zoonose & 407 & 0 \\
\hline Gibier + santé + zoothérapie & 13 & 0 \\
\hline Gibier + santé + "médecine traditionelle" & 376 & 0 \\
\hline Gibier + santé + "animaux médicinaux" & 5 & 0 \\
\hline TOTAL & 3266 & 1 \\
\hline Snow ball & & 20 \\
\hline TOTAL & 13827 & 73 \\
\hline
\end{tabular}




\section{ONLY studies containing} information on the topics of interest to our research: We selected studies only if they provided primary information on one or more of the following topics: nutritional or toxic content of bushmeat, pathogens found in bushmeat species with potential transmission to humans ("zoonotic pool" in bushmeat species), and zoo-therapeutic uses of bushmeat.

3. Scientific merit: To ensure the scientific quality of the information reported, we only selected peer-reviewed documents such as scientific journal articles, book chapters, theses for an academic degree, or books.

4. ONLY studies providing primary information: Studies that used secondary data generated by other studies were not included. As far as possible, we tried to search for the primary source when it was cited in studies found through the word combination search.

The references that passed this first filter were then screened by their full text and selected using the secondary criteria below:

1. ONLY case studies from tropical and sub-tropical forests: We selected studies on bushmeat in tropical and sub-tropical forests as defined by Olson et al. (2001). Tropical forests are restricted to land area between the latitudes $23.5^{\circ}$ North and $23.5^{\circ}$ South of the equator, or in other words between the Tropic of Capricorn and the Tropic of Cancer. Tropical and Sub-tropical forests can be split into four areas: 1) Neotropical region, 2) Central Africa/ Afrotropical region, 3) Oriental or Indomalayan/Asian region and 4) Australasian region. We also included the Caatinga region in Brazil as several humid forest remnants are found in this ecosystem. Studies conducted in other parts of the world but referring to species that also occur in tropical and sub-tropical regions were also taken into account.

2. ONLY studies on bushmeat species hunted in the wild: We did not include studies that examined meat from wild species raised in domesticated environments.

3. ONLY studies referring to bushmeat species as defined by the Bushmeat Working Group from CITES: Bushmeat is defined as "meat for human consumption derived from wild animals" (CITES 2000). In addition, the CBD working group on bushmeat restricts the definition to mammals, birds, reptiles and amphibians (Nasi et al. 2008). This definition excludes aquatic animals, insects and molluscs. As such, the definition of bushmeat used here refers to mammals, birds, reptiles and amphibians consumed by humans for food or medicinal purposes.

4. Our focus is on bushmeat or the use of wild animals consumed for their meat, and not on wild animals in general. As such, for studies that reported on presence or prevalence of zoonotic diseases, we selected ONLY those that referred to zoonosis transmitted to humans through the handling or consumption of bushmeat. For studies on the zootherapeutic uses of bushmeat, we selected ONLY those that described the use of parts of the animal that are consumed for therapeutic purposes (meat, intestine, head, penis, fat, anus, bones etc.). Several studies on the zoonotic use of animals did not describe any consumptive use and were therefore not included. For example, studies on the use of snakes to produce creams for external use or objects used for witchcraft were not included in this study. Papers that only described a given species as being used for medicinal purposes without detailing the particular animal part(s) and its 
specific use were also considered ineligible.

For each of the studies that passed our filter $(\mathrm{N}=112)$, we extracted the following information:

- For studies on the nutritional content or toxic contamination of bushmeat species: species, part of animal tested, micronutrients (Iron, Zinc, Potassium, Phosphorus, Calcium, Sodium, Manganese), lipids, fiber, protein, ash, carbohydrates, moisture, toxic content

- For studies on the zoo-therapeutic uses of bushmeat species: species, part of the animal used, preparation, target population, illness prevented, illness cured, ethnic origin of the users.

- For studies on the zoonotic pool of bushmeat species: species, part of the animal sampled, disease agent.

The information was organized in a structured database. Each of the studies was recorded in the database with information on authors, publication date, title, publication type, geographic position of study site, country.

\section{RESULTS}

\section{General description of the data:}

Among the 112 studies selected, 72 describe the zoonotic pool in bushmeat species, 21 report on the nutritional content of bushmeat and 19 report on the zootherapeutic uses of bushmeat (Figure 2).

Over the last 5 years, there has been an exponential increase in the number of studies on the zoonotic potential and nutritional value of bushmeat species. Studies on the zoo-therapeutic use of bushmeat have remained rather constant over the last 10 years.

Within the tropical and sub-tropical forests biome, the geographic distribution of case studies shows a concentration of studies in Africa ( $n=67$ ) (Figure 3). A few studies report on Asia and the Pacific (India, Bangladesh, Australia, Malaysia, Thailand, China and Papua New Guinea, n=14). In Latin America and Caribbean $(n=32)$, studies were conducted in Brazil, Peru, Ecuador, Saint Kitts, Colombia, Mexico, French Guiana and Venezuela. Studies on the zoonotic potential of bushmeat species are concentrated in Central Africa and West Africa, while studies on the nutritional content of bushmeat originate mainly from South America and West Africa. The zoo-therapeutic uses of bushmeat have seen greater research emphasis in Latin America and particularly Brazil compared to any other region.

\section{Nutritional content and toxic contamination of bushmeat}

Studies on the nutritional content of bushmeat vary in terms of the variables analyzed (vitamins, fat, moisture, carbohydrates, minerals, proteins, ash, fiber, metal element contaminations), in terms of the samples used (cooked, dried, salted, fresh, and smoked meat) and part of the animal used (meat, muscle, liver, kidney) (Annex 1). Some studies did not mention the species used for the analysis and the sample was only categorized as bushmeat.

Several studies conducted in sub-tropical and tropical forests of Africa analyzed the nutritional content of bushmeat. Malaisse and Parent (1982) concluded that rodents from the Miombo forest form an important subsidiary food whose nutritive value places them on the same level as beef or chicken. According to the authors, wild rodents, while not included in the F.A.O. Food Balance Sheets because they are not accounted for in national surveys, make a significant contribution to the quantity and quality of 


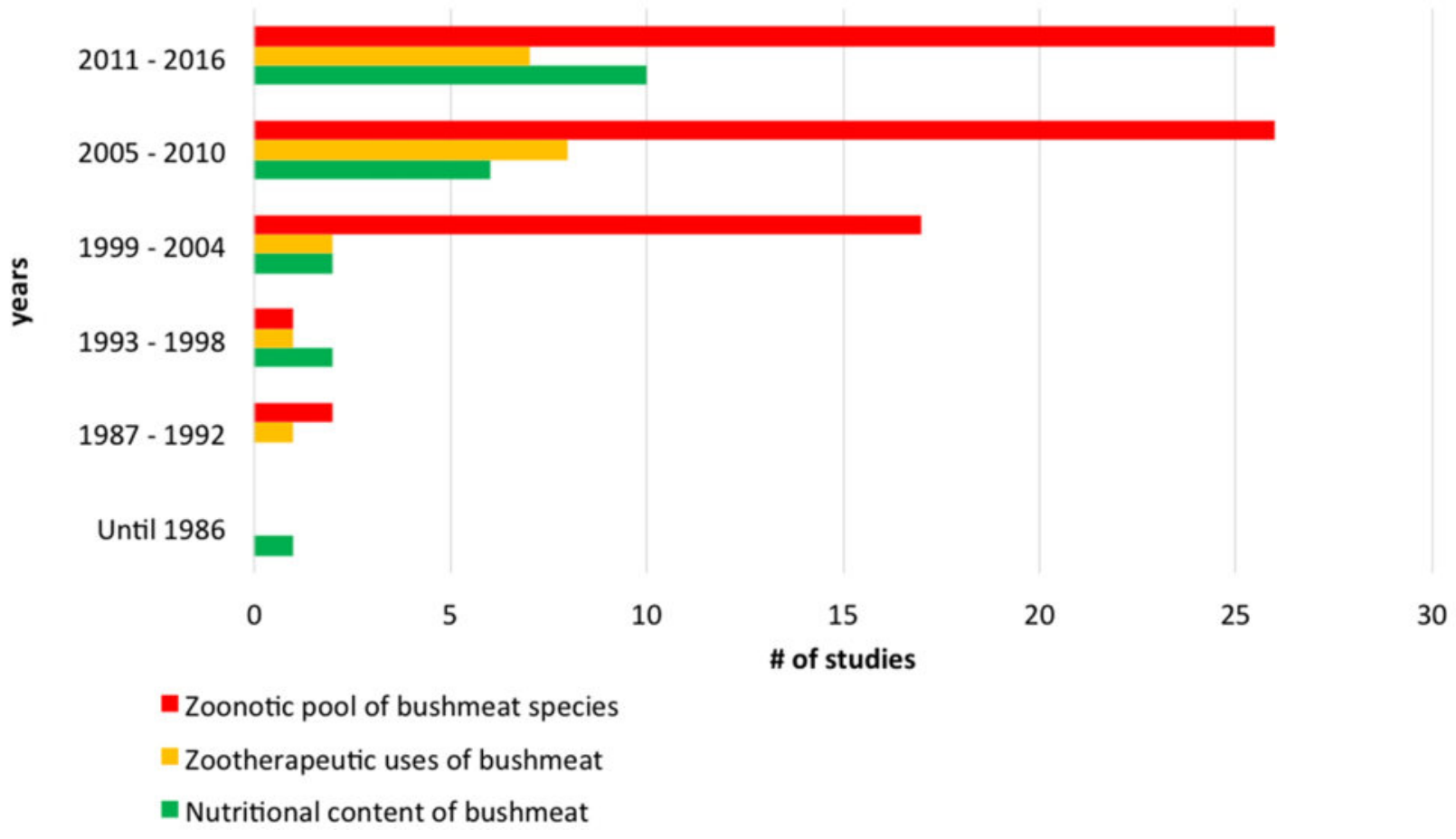

Figure 2. Number of studies per topic and year published

foods eaten by communities in rural areas. Olawale-Abulude (2007) analyzed the nutritional content of fresh bushmeat from a variety of species in Nigeria (including rodents, snakes, birds, bats and squirrels), and concluded that their use as sources of food was to be encouraged given their nutritional values in terms of protein and minerals and their good digestibility. Adei and Forson (2008) analyzed the livers of grass cutters and found higher concentrations of iron compared to the livers of domestic animals present in the market in Ghana. Similarly, Oyarekua et al. (2010) analyzed the nutrient composition of the African rat and concluded that the limb muscle was the more desirable in terms of nutritive value, due to its high iron, protein, potassium, magnesium and zinc content. Adeyeye and Jegede (2010) and Adeyeye et al. (2012) analyzed the amino acid profile of the greater cane rat and found that its muscle, liver and skin have high levels of most of the essential amino acids and phospholipids, although the skin and liver also contained high levels of cholesterol. Onadeko et al. (2011) analyzed the nutritional value of frogs (Hoplobatrachus occipitalis, Xenopus muelleri and Ptychadena pumilio) in Nigeria and concluded that the amino acid composition of frog meat can be compared to those of the Clarias sp. and Tilapia sp. and are valuable sources of protein for low-income consumers. Roger et al. (2012) analyzed the nutritional value of cooked bushmeat in Northern Cameroon with each sample representing a different bushmeat recipe. Niyi (2014) analyzed the nutritional content for the African wild antelope, Antilocapra americana in Nigeria and concluded that the meat was a positive source of protein, minerals and essential amino acids and had no negative health implications on the consumers since it had low levels of anti-nutrients (compounds that interfere with the absorption of nutrients). A 


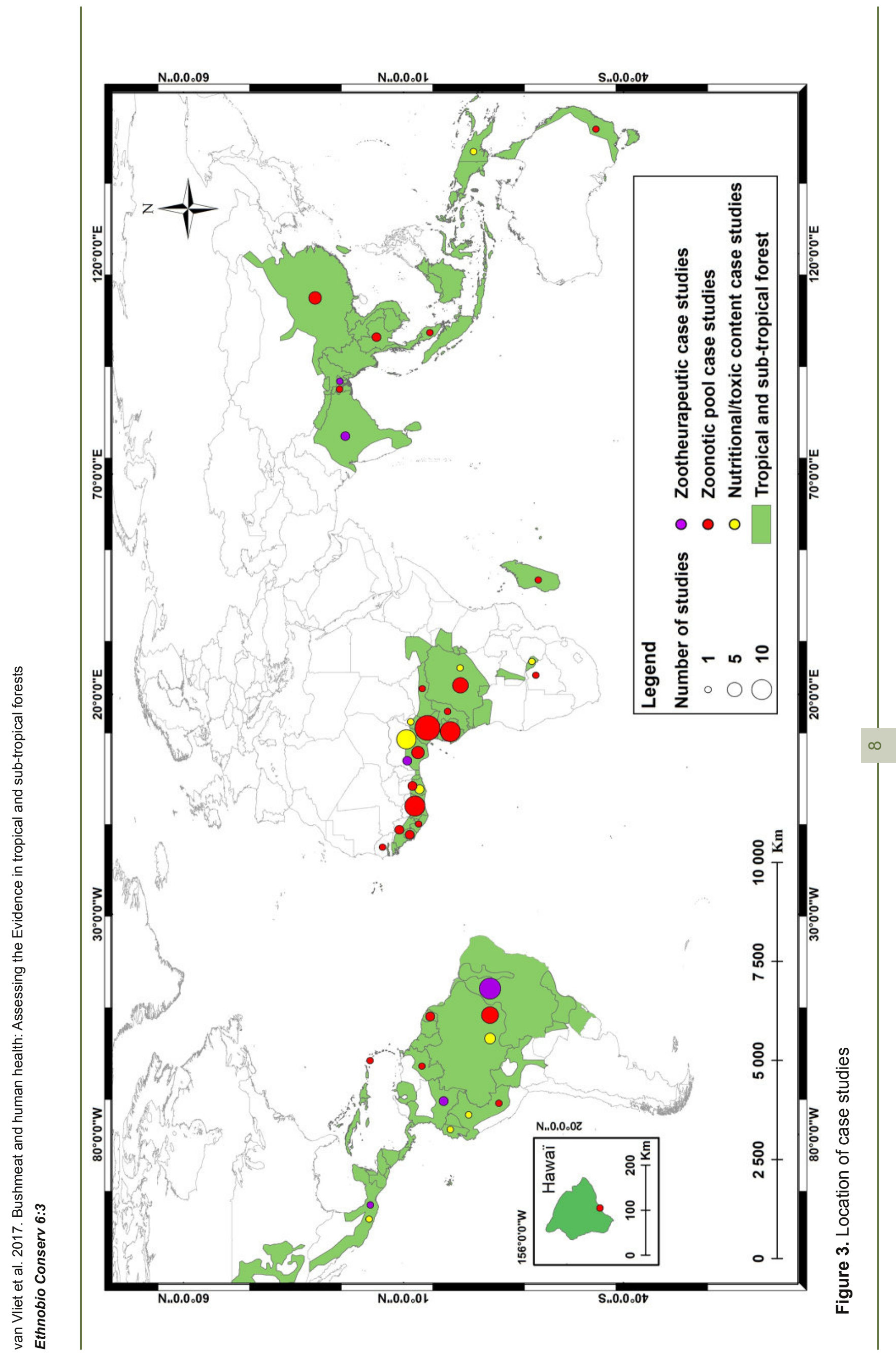


recent study in Congo analyzed the fatty acid profile of blue duiker's meat and porcupine meat (Mananga et al. 2015) and concluded that the consumption of those two species provides essential linoleic and arachidonic fatty acids, which contribute to the plasticity of the organism, and oleic fatty acid which favors the development of the good cholesterol to prevent cardiovascular diseases.

Additional studies in Nigeria and Ghana analyzed the presence of toxic elements in bushmeat. Adei and Forson (2008) examined the livers of grass cutters in Ghana and concluded that livers can be a significant source of heavy metals $(\mathrm{Cd}, \mathrm{Hg}$, $\mathrm{Pb}$ ) in the diet. Igene et al. (2015) and Soewu et al. (2014) analyzed metal contamination on fresh and dried grass cutter (Thryonomys swinderianus) in Nigeria and found the meat unsafe for consumption given their high concentration of nickel and chromium. The authors hypothesize that these concentration levels might come from contaminated water and soils due to mining or smelting waste-water production, cooking with nickel-steel alloy utensils, and eating from nickel-pigmented dishes. Yemi et al. (2015) found a high concentration of heavy metals in Cephalophus spp. hunted in an agricultural landscape from Nigeria that may be caused by acute or chronic contamination of their diet and habitat. Abdul et al. (2014) analyzed the polycyclic aromatic hydrocarbons (PAH) in smoked bushmeat in Ghana and found that bushmeat smoked with gas produced smaller $\mathrm{PAH}$ values compared to bushmeat smoked using wood mixed with spent oil, plastics mixed with refuse, and discarded car tires.

For Latin America, only six studies reported on the nutritional content of bushmeat. Aguiar (1996) analyzed the nutrient composition of several bushmeat species in the Brazilian Amazon and concluded that bushmeat species are generally low in fat content. The meat with the highest concentration of proteins was that of capybara $(24,58 \mathrm{~g} / 100 \mathrm{~g})$. The meat with highest concentration of energy was that of tapir $(127,34 \mathrm{~g} / 100 \mathrm{~g})$ and the meat with the highest content in fat was that of a Six-tubercled Amazon River turtle (Podocnemis sextuberculata, $\quad 5.56 \mathrm{~g} / 100 \mathrm{~g}$ ). Cordón and Salazar de Ariza (1999) analyzed the nutritional content of cooked meat from five species in Mexico (Mazama americana, Pecari tayacu, Tayassu pecari, Crax sp., Cuniculus paca), using a different recipe for each species, taking into account local culinary traditions. The study concluded that bushmeat consumption (every 15 days as observed in the studied communities) contributed significantly to healthy diets due to the high values of protein and minerals contained in the bushmeat species. Galvez et al. (1999) analyzed the nutritional content of the four most commonly consumed species in Iquitos, Peru (Tayassu pecari, Geochelone denticulata, Agouti paca and Mazama americana) and concluded that bushmeat contained a higher value of proteins and a lower fat content as compared to alternative proteins of domestic origin (beef, mutton, rabbit, etc). Siren and Machoa (2008) analyzed the nutrient content on bushmeat in Ecuador and found that if the availability of wild meat and fish decreases, the most serious effect would be a decrease in the already low intake of fat. Felix (2012) analyzed the nutritional quality of capybara meat in Brazil and found that it presented nutritional characteristics similar to those of farmed capybara, and that the meat from sustainably used capybara was suitable for commercialization based on its nutritional qualities. The study from Lemire et al. (2010) analyzed the content of selenium in various 
foods consumed by Amazonian riverside populations and found that paca $(1,06 \mu \mathrm{g} / \mathrm{g})$ and armadillo $(0,52 \mu \mathrm{g} / \mathrm{g})$ meat had a higher concentration of selenium than chicken and beef. Trace amounts of selenium are usually necessary for cellular function and may be important to counteract mercury $(\mathrm{Hg})$ toxicity.

Only one study was found from Asia and the Pacific. Smith et al. (1993) analyzed the relationship between dietary composition and the height of children in Papua New Guinea and found that the consumption of bushmeat (together with fresh fish) had the strongest association with increased heights, and also contained the highest protein to energy ratios and high fat to energy ratios.

\section{Zootherapeutic uses of bushmeat}

Nineteen studies report on the zootherapeutic uses of bushmeat to either treat or prevent illnesses, and were conducted in India, Bangladesh, Nigeria, Brazil and Colombia (Annex 2). Different parts of the animals were used (e.g. the entire animal, its meat, intestines, penis, placenta, tail, anus, head, bill, gizzard), and their preparation with other ingredients (plant or animal products) were used in medicinal recipes to treat multiple diseases. In total, seventy-six bushmeat species were mentioned as having zoo-therapeutic purposes through their consumption.

In Nigeria, Adeola et al, (1992) described the use of 10 species by Nigerian farmers: the use of the intestines of Cephalophus grimmia (grey duiker) to cure stomach ache; the use of Kinixys belliana (a tortoise) to cure chest pain, the use of the intestines from Crocodilus niloticus (Nile crocodile) to prevent poisoning, the legs of Phacochoerus africanus (warthog) to prevent from lameness, the penis from Gorilla gorilla (gorilla) to prevent from poison, the head of Manis tricuspis (tree pangolin) to stop bleeding, the anus from Civettictis civetta (African civet) to prevent against convulsions, the intestines of Atherurus africanus (bush tailed porcupine) to cure stomach ache, the squirrel to prevent convulsions in children and python fat to cure rheumatism. The meat from African giant snail (Achatina achatina and Achatina marginata) is used to cure whooping cough, anemia, ulcer, asthma, hypertension, bone fracture and infertility in women (Agbogidi 2010). In addition, a certain number of species are used as aphrodisiacs (the penis of the chimpanzee, baboon, squirrel, warthog, buffalo, mona monkey, tree hyraz; the entire body of the tree hyrax, tortoise, parrot; the foot of the guinea fowl; the heart or tail of the cobra, the cane rat, and the puff adder) or to increase fertility in women (the flesh of the warthog, African civet, python, baboon, tortoise; the whole body of the bat, African giant rat, cane rat, African giant snail, squirrel and giant fowl; the placenta of the chimpanzee and mona monkey; the intestine of the cobra, puff adder and python).

In India, Solavan et al. (2014) described the use of Varanus salvator prepared with the skeleton and mixed with 3 liters of coconut milk, $50 \mathrm{~g}$ of ganja leaf, administered twice a day for 40 days to cure arthritis, and the use of the meat from Presbytis johnii cooked with the seeds of Piper nigrum, the stem of Zingiber officinale, root of the Allium sativum, cow's ghee and the natural honey to cure asthma in children below 11 years old. In Assam, India, Hanse and Teron (2012), described the use of cooked meat from Pteropus medius (flying fox) to cure joint pain, the use of Cervulus muntjac, (barking deer) which legs are used to cook a soup that relieves chest pain, rheumatic pain and fever, and the use of Vulpes sp., fox, which flesh is cooked and eaten to relieve joint pain and fever. The Mro in Bangladesh cook the meat of Sus scrofa 
(Eurasian wild pig) and Canis aureus (Asian Jackal) to relieve arthritis and rheumatism (Chowdhury et al., 2014).

In Brazil, fifty one species and different parts of the animals are consumed to treat or prevent diseases (see the long list in Annex 2) (Costa-Neto 2004; Alves and Filho 2006; Alves and Rosa 2007; Alves and Santana 2008; Alves et al. 2009; Ferreira et al. 2009; Alves et al. 2010; Barros et al. 2011; Ferreira et al. 2012; Pinto et al. 2012; Barros and Azevedo, 2014). The categories of illnesses most frequently mentioned were diseases of the respiratory tract (asthma, sore throat, and cough) and the musculoskeletal system and connective tissue. In Mexico, MoralesMavíl and Villa-Cañedo (1998) report the use of dried meat from Crotalus durissus to prevent cancer, the meat from Didelphis virginiana cooked in a soup or smoked to cure skin problems and anemia, the use of the bone from the penis of Nasua narica consumed as aphrodisiac and the meat from Conepatus semistriatus as a remedy against acne. In Colombia, the Cofnes (an indigenous group from the Putumayo region) use the whole animal of Didelphis marsupialis to cure acne and purify blood (CamachoMartínez 2013). The Pastos (another indigenous group from the Putumayo region) use Cavia porcellus for a variety of illnesses including stress, cold, weakness of the brain and headache, weakening of the uterus in women and avoid excessive salivary flow among children (Camacho-Martínez 2013). In the Pacific region of Colombia, rural populations use the fat from Caiman crocodilus fuscus to cure asthma, the biliary vesicle of Cuniculus paca as an analgesic, the liver from rodents (Proechimys semispinosus, Hoplomys gymnurus, Didelphys marsupialis and Metachirus nudicaudatus) as a hormonal stimulant to give birth, the fat from Tamandua mexicana to cure arthritis, the penis and testicles from Potos flavus as an aphrodisiac (Cuesta-Rios 2007).

\section{Zoonotic pool in bushmeat species with potential spillover to humans}

Because the study of reservoir systems and how infectious agents move between and within them can be complex, only a few cases provide evidence of the transmission of pathogens from wildlife to humans (Kurpiers et al. 2016). Several pathogens found in bushmeat species are zoonotic and may potentially be transmitted to humans. However, not all of them are transmitted through the consumption of bushmeat itself. Many viruses are actually transmitted to humans through exposure to body fluids and feces during the handling and butchering of bushmeat prior to cooking.

\section{Tropical and sub-tropical forest areas in Africa}

A detailed description of pathogens in bushmeat species from Africa is also available in Kurpiers et al. (2016). Here, we specifically report on the tropical and subtropical forests of Africa, where a total of 50 studies describe the existence of viruses, bacteria, protozoa and parasites in small primate species in particular, but also in ungulates, birds, reptiles, rodents and apes (see Annex 3). Twenty-five types of parasites were evidenced in bushmeat species from Africa. The most abundant parasites in bushmeat species were Trichuris sp., Ancylostoma sp., Ascaris, Toxoplasma gondii and Strongyloides fulleborni, most frequently transmitted from simians, rodents or ungulates to humans through a fecal-oral route (Annex 3: Zoonotic Parasites in bushmeat species from Africa).

The literature available provides records for nine main types of viruses (SIV; HTLVs, 
Foamy viruses, Monkey pox, Marburg virus, Lassa virus, Ebola, Nipah virus and Herpes) that can be transmitted to humans (Wolfe et al, 2004) and is hosted mainly by small primates, apes and Chiroptera (Annex 3: Zoonotic viruses present in bushmeat of species in Africa). Eight types of bacteria were reported in rodents, ungulates and apes (Annex 3: Zoonotic bacteria and other diseases present in bushmeat of species in Africa). The most common bacteria are Escherichia coli, Salmonella spp., and Campylobacter spp.

\section{Latin America and Caribbean}

In Latin America and Caribbean, thirteen studies describe the presence of parasites and bacteria in 19 bushmeat species (Annex 3: Zoonotic parasites in bushmeat of species in Latin America and Caribbean). Toxoplasma gondii, a ubiquitous protozoan parasite capable of infecting all warm-blooded animals, was found in several terrestrial mammals (Carme et al. 2002; Thoisy et al. 2003; Da Silva 2006; Truppel et al. 2010; Hamilton et al. 2014). Toxoplasmosis has a wide spectrum of clinical responses following infection, which ranges from acute fatal disease, congenital disease, behavioural changes and no obvious clinical signs (Innes 2010). Echinococcus vogeli was found in Cuniculus paca (Mayor et al. 2015), which is among the most hunted species in the Amazon region. The high prevalence of polycystic echinococcosis in pacas confirms that pacas are intermediate hosts. Because bushmeat viscera are usually used to feed dogs, humans might be consequentially infected through contact with feces from infected dogs. Capillaria hepatica was found in Tayassu peccary and Ateles paniscus (PereiraSoares et al. 2011) and can be transmitted to humans if they consume the viscera of infected animals. Tripanosoma cruzi, responsible for Chagas disease, was found in porcupine (Coendou spp.), grey four eyed opossum (Philander opossum) and ninebanded armadillo (Dasypus novemcinctus) (Coura et al. 2002). Echinococcus vogeli, responsable for echinococcosis disease and Calodium hepaticum, was found in paca (Cuniculus paca) (Almeida et al. 2013; Mayor et al. 2015).

Several bacteria responsible for gastroenteritis and enteric diseases were found in the raw meat of peccaries and capybara (Sarkis 2002; Annex 3: Zoonotic bacteria in bushmeat of species in Latin America and Caribbean) with possibilities for transmission to humans through the consumption of bushmeat species in rural and urban areas. Brucella suis, a type of bacteria that can cause diseases in humans and domestic animals of economic importance alike, was found in collared peccaries from Venezuela (Lord and Lord et al. 1991). Mycobacterium leprae was found in the nine-banded armadillo as well as in the six-banded armadillo (Cunga-Frota et al. 2012). The exact mode of transmission of leprosy between humans and armadillos is not known, but several studies have shown an association between the hunting, cleaning and eating of armadillos and the development of leprosy in human populations (Clark et al. 2008; Deps et al. 2008; Truman 2008). Armadillos are widely used in folk medicine and are a natural reservoir of etiological agents of several zoonotic diseases that affect humans such as leprosy, trichinosis, coccidioidomycosis or Valley Fever, Chaga's disease, typhus, and pulmonary micosis (Silva et al. 2005).

\section{Asia and the Pacific}

Very little data is available regarding the 
zoonotic pool of bushmeat species from Asia and the Pacific. Escherichia coli and Salmonella were found in kangaroo meat (Holds et al., 2007). Madar et al. (2012) found the presence of salmonella in Axis Axis in Hawai (see Annex 2: Zoonotic bacteria and parasites in bushmeat of species in Asia and Pacific). Four viruses were found in bushmeat species from Asia (Nipah virus, SARS coronavirus, Ebola, A/H5N1), particularly in bat species from South East Asia and China (see Annex 3: Zoonotic viruses present in bushmeat of species in Asia and Pacific).

\section{DISCUSSION}

Our findings are constrained by the type and nature of the collected information. For example, we were limited by not being able to select studies that did not make an explicit link between bushmeat and outcomes of interest (should they not make reference to the words bushmeat, game meat, or wild meat in the different languages used for the search). Studies on the nutritional content, zoo-therapeutic uses or zoonotic pool of wild animals that did not make explicit mention of consumptive use were excluded from this search to avoid collecting information on wild animals more broadly without consideration of their use as bushmeat. An alternative approach to find relevant studies would have been to conduct a species-by-species search based on the list of harvested animals for food in each of the geographical regions. However, this methodology would have expanded search efforts far beyond our capacity. Indeed, about 301 species for mammals alone, are known to be used for food (Ripple et al. 2016).

Despite these limitations, a striking result of this systematic review is the paucity of available data concerning the nutritional content of the most important bushmeat species, particularly from the tropical forests of Central and West Africa. Indeed, none of the nutritional studies provide data on species such as duikers, bush tailed porcupine and primates, which are among the most hunted species for food in the tropical forests of Africa (Nasi et al. 2011). Another striking result is the lack of standard methodology for the analysis of the nutritional content of bushmeat (part of the animal, state of the sample, variables measured, units used), which makes comparison between studies difficult. However, the majority of studies on the nutritional content of bushmeat species conclude that bushmeat contributes positively to overall dietary intake. These results are corroborated by other studies that have analyzed the nutritional status of bushmeat consuming populations. In traditional societies, bushmeat provides the greatest amount of daily calories (Smith et al. 1993), is a crucial source of micronutrients (Golden et al. 2011; Sarti et al. 2015) and fat (Siren and Machoa 2008) and continues to play an important role in terms of dietary diversity for modern forest societies (van Vliet et al. 2015). In their literature review, King and Furgal (2014) provided strong arguments for the consumption of wild meats based on their high nutritional content, especially in contexts where the incidence of obesity, diabetes, cardiovascular disease and their associated adverse health outcomes are increasing (e.g. among indigenous groups in the Artic). On the other hand, other studies also show that many tropical forest societies have been able to substitute bushmeat with other domestic protein sources in their dietary intake (Byron (2003) in Ecuador; Vega et al., (2013) in Equatorial Guinea).

Concerning the zoonotic pool of 
bushmeat species, the collected studies clearly suggest that bushmeat does not constitute a health risk if strict hygiene and food safety practices with respect to the handling, butchering and preparation of bushmeat are followed. However, given current practices in forest regions, hunters may face risk of transmission if injured by an animal that is still alive, or when they carry their prey back home, or when they cut themselves during butchering (Subramanian 2012), facilitating the transfer of body fluids (LeBreton et al. 2006). The highest risk of disease transmission actually occurs during the butchering of animals, which includes women who engage in butchering at market and in food preparation. Very few precautions are taken by bushmeat users to avoid contact with bodily fluids (LeBreton et al. 2006; Yang et al. 2007; Kamins et al. 2014). For example, they do not typically use protective measures such as gloves (Kamins et al. 2014). According to Calvignac-Spencer et al. (2012), increased surveillance for zoonotic transmission of bushmeat pathogens to humans in areas where such transmission is more likely will contribute to a better understanding and prevention of risk factors. However, other factors besides hunting have also facilitated the spread of retroviruses (e.g deforestation, increased urbanization, travel, increased unsafe injections and transfusions) and their impact should also be carefully monitored to reduce transmission risks (Mouinga-Ondémé and Kazanji 2013). On the consumption side, bushmeat may represent a risk if the meat is inadequately cooked. Roasted bushmeat constitutes a high risk if only superficially roasted (Sidorowicz 1974). However, bushmeat is traditionally cooked for several hours before consumption, which reduces such risk, including the transmission of anthrax spores (Spotts Whitney et al. 2003) and monkeypox virus (Hahon and Kozikowski 1961). Bushmeat can also be contaminated by metals if the water, cooking utensils, and type of fuel used are not suitable for human consumption (Abdul et al. 2014; Igene et al. 2015). The means of transportation packing methods used during bushmeat transportation are other factors that may cause the contamination of bushmeat by pathogens. Food safety risks stemming bushmeat handling practices from tropical and sub-tropical forest areas is nonetheless comparable to deficiencies in domesticated meat handling practices in the same regions due to a lack of safe water, waste management, adequate infrastructure and knowledge with regards to food safety practices (King and Furgal 2014).

Concerning the zoonotic pool of bushmeat species, the available literature highlights the significant attention paid to viral infections linked to bushmeat handling practices (particularly that of primates) following the recent pandemics caused by zoonotic diseases (HIV and Ebola). On the other hand, bacterial and parasite infections have received less attention but constitute a major cause for the deaths of millions of users across tropical and sub-tropical forest areas. These common diseases deserve closer attention. Improving access to safe water, gloves, and modern tools for butchering and cooking could be envisaged among the strategies to reduce such disease transmission. Given the likely increase in consumption of non-traditional meats in the future (Hoffman and Cawthorn 2013), issues that would require further research include all facets of production and processing following the best and most culturally accepted food safety practices.

Several studies also report that a large number of animal species are used for medicinal purposes in rural and urban areas 
worldwide, particularly in African, Asian, and Latin American countries. In these areas, the trade of wildlife-based medicinal products is concentrated in local and traditional markets, where various species of medicinal plants and animals are commercialized (Alves et al. $2013 \mathrm{~b}$ ). The hygiene of medicinal products sold at markets is unknown, but probably varies enormously between traders and traditional healers (Mander et al. 2007). In Brazil, for example, Alves and Rosa (2007) ranked the sanitary conditions of the zootherapeutic products as poor. Alves et al. (2013b) highlights the need for further assessments of the sanitary conditions of commercialized medicinal products, as well as the need for the implementation of measures to address the sanitary aspects of the trade in animals and their parts for medicinal or nutritional purposes.

Another dimension of health that was not addressed in this study but that requires further consideration is the role of mental health. Indeed, hunting and its associated social and cultural forms have shown to contribute to the mental health and cultural continuity in traditional communities (Samson Pretty 2006). Thomas (1987) used the term "meat hunger" to refer to the mental health problems (complaints of tiredness, loss of vital strength and depression), related to the occasional lack of meat among nomadic hunter-gatherers like African Pygmies and Punan (Thomas 1987). As such, bushmeat is essential for health not only because it is a vital source of nutrients, but also because it contributes the vitality of hunters and communities at large (MotteFlorac et al. 1993). According to Dounias and Froment (2011), mental diseases like stress and depression are increasingly observed among former forest foragers, partly because sedentism has decreased their access to meat from the forest.
"Is bushmeat healthy or the opposite?" is not a simple question. Despite the importance of this question, the existing literature appears to have approached this question in a fragmented manner. This paper demonstrates the need for more in-depth studies in tropical and sub-tropical forest regions about the complex links between bushmeat and human health, particularly concerning the nutritional content of bushmeat, the pathogens that may see zoonotic transmission and the zootherapeutic uses of bushmeat. The results generated should help the development and testing of innovative approaches to reduce the negative impacts of bushmeat consumption on human health through better food handling and conservation practices, and further acknowledge the positive nutritional and medicinal values of bushmeat use. Further studies should also take into consideration that hunting and bushmeat consumption are not practiced in isolation of culture, society, economics, environment, politics or technology. A balance needs to be struck between the quantitative perspectives of epidemiology, and the powerful qualitative information derived from other disciplines. Bushmeat management will depend on understanding and working with people, with any approach based too narrowly in one or the other disciplines running the risk of failure in the long term (Cawthorn Hoffman, 2015). The reviewed literature also demonstrates the importance of understanding hunting and bushmeat consumption practices within the changing environments in which they are occurring (van Vliet et al. 2015). As such, transdisciplinary approaches (including ethnozoology, epidemiology, anthropology, sociology, food technology, biology and ecology, etc) need to be integrated to recognize that the links between bushmeat 
and human health arise from highly complex interactions.

\section{ACKNOWLEDGEMENTS}

This work was possible thanks to the financial support from USAID and UKAID, through the Bushmeat Research Initiative from CIFOR under the CGIAR Forest, Trees and Agroforestry program.

\section{REFERENCES}

Abdul IW, Amoamah MO, Abdallah A (2014) Determinants of polycyclic aromatic hydrocarbons in smoked bushmeat. International Journal of Nutrition and Food Sciences 3(1): 1-6

Abulude FO (2007) Determination of the chemical composition of bush meats found in Nigeria. American Journal of Food Technology 2(3): 153-160

Adei E, Forson-Adaboh K (2008) Toxic (Pb, Cd, Hg) and essential ( $\mathrm{Fe}, \mathrm{Cu}, \mathrm{Zn}, \mathrm{Mn}$ ) metal content of liver tissue of some domestic and bush animals in Ghana. Food Additives and Contaminants: Part B 1(2):100-105

Adejinmi JO, Emikpe GE (2011) Helminth parasites of some wildlife in Asejire Game Reserve, Nigeria. South African Journal of Wildlife Research 41(2): 214-217

Adeola MO (1992) Importance of wild animals and their parts in the culture, religious festivals, and traditional medicine, of Nigeria. Environmental Conservation 19(02): 125-134

Adeyeye El, Jegede RO (2010) Muscle and skin amino acid compositions of the greater cane rat (Thryonomys swingerianus). International Journal of Pharma and Bio Sciences 1(3): 1-9

Adeyeye El, Olaofe O, Ogunjana KE (2012) Lipid profiles of the skin, muscle and liver of greater cane rat (thryonomys swingerian us): dietary implications. Elixir Food Science 53: 11749-1175

Agbogidi OM (2010) Ethno-botanical survey of the non-timber forest products in Sapele Local Government Area of Delta state, Nigeria. African Journal of Plant Science 4(6): 183189
Aghokeng AF, Ayouba A, Mpoudi-Ngole E, Loul S, Liegeois F, Delaporte E, Peeters M (2010) Extensive survey on the prevalence and genetic diversity of SIVs in primate bushmeat provides insights into risks for potential new cross-species transmissions. Infection, Genetics and Evolution 10(3): 386-396

Aghokeng AF, Ayouba A, Mpoudi-Ngole E, Loul S, Liegeois F, Delaporte E, Peeters M (2010) Extensive survey on the prevalence and genetic diversity of SIVs in primate bushmeat provides insights into risks for potential new cross-species transmissions. Infection, Genetics and Evolution 10(3): 386-396

Aghokeng AF, Bailes E, Loul S, Courgnaud V, Mpoudi-Ngolle E, Sharp PM, Delaporte E, Peeters M (2007) Full-length sequence analysis of SIVmus in wild populations of mustached monkeys (Cercopithecus cephus) from Cameroon provides evidence for two cocirculating SIVmus lineages. Virology 360(2): 407-418

Aguiar JPL (1996) Notas e Comunicações. Tabela de Composição de Alimentos da Amazônia. Acta Amazônica 26(1/2): 121-126

Ahuka-Mundeke $S$, Mbala-Kingebeni $P$, Liegeois F, Ayouba A, Lunguya-Metila O, Demba D, Bilulu G, Mbenzo-Abokome B, Inogwabini BI, Muyembe-Tamfum JJ, Delaporte E, Peeters M (2012) Identification and molecular characterization of new simian $T$ cell lymphotropic viruses in nonhuman primates bushmeat from the Democratic Republic of Congo. AIDS research and human retroviruses 28(6): 628-630

Almeida F, Caldas R, Corrêa C, Rodrigues-Silva R, Siqueira N, Machado-Silva JR (2013) Coinfections of the cestode Echinococcus vogeli and the nematode Calodium hepaticum in the hystricomorphic rodent Agouti paca from a forest reserve in Acre, Brazil. Journal of helminthology 87(04): 489-493

Alves RRN, Feijó A, Barboza RRD, Souto WMS, Fernandes-Ferreira $\mathrm{H}$, Cordeiro-Estrela $\mathrm{P}$, Langguth A (2016) Game mammals of the Caatinga biome. Ethnobiology and Conservation 5:1-51

Alves RRN, Filho GA (2006) Commercialization and use of snakes in North and Northeastern Brazil: implications for conservation and management. Biodiversity and Conservation 16(4):143-159 
Alves RRN, Léo-Neto NA, Brooks SE, Alburquerque UP (2009) Commercialization of animal-derived remedies as complementary medicine in the semi-arid region of Northeastern Brazil. Journal of Ethnopharmacology 12: 600-608

Alves RRN, Lima MM, Fonseca C, Dos Reis R, Figueiredo $\mathrm{PH}$, Costa $\mathrm{H}$, Kreuser L, Nunes MC, Ribeiro AL (2016) Peak oxygen uptake during the incremental shuttle walk test in a predominantly female population with Chagas heart disease. European journal of physical and rehabilitation medicine 52(1): 20-27

Alves RRN, Oliveira MDGG, Barboza RRD, Lopez LCS (2010) An ethnozoological survey of medicinal animals commercialized in the markets of Campina Grande, NE Brazil. Human Ecology Review 17(1): 11-17

Alves RRN, Oliveira TPR, Rosa IL (2013a) Wild animals used as food medicine in Brazil. Evidence-Based Complementary and Alternative Medicine 2013, 1-13.

Alves RRN, Rosa IL (2007) Zootherapy goes to town: The use of animal-based remedies in urban areas of $\mathbf{N E}$ and $\mathbf{N}$ Brazil. Journal of Ethnopharmacology 113: 541-555

Alves RRN, Rosa IL (2013) Introduction: Toward a Plural Approach to the Study of Medicinal Animals. In: Alves RRN Rosa IL (eds) Animals in Traditional Folk Medicine: implications for conservation. Springer-Verlag, Berlin Heidelberg, pp. 1-9

Alves RRN, Rosa IL, Albuquerque UP Cunningham AB (2013b) Medicine from the wild: an overview of the use and trade of animal products in traditional medicines. In: Alves RRN, Rosa IL (eds) Animals in Traditional Folk Medicine: implications for conservation. Springer-Verlag, Berlin Heidelberg, pp. 25-42

Alves RRN, Santana GG (2008) Use and commercialization of Podocnemis expansa (Schweiger 1812) (Testudines: Podocnemididae) for medicinal purposes in two communities in North of Brazil. Journal of Ethnobiology and Ethnomedicine 4(3), 1-6

Apetrei C, Metzger MJ, Richardson D, Ling B, Telfer PT, Reed P, Roberston DL, Marx PA (2005) Detection and partial characterization of simian immunodeficiency virus SIVsm strains from bush meat samples from rural Sierra Leone. Journal of virology 79(4): 2631-2636.
Cordón K, Salazar de Ariza J (1999) Composición química de carnes de animales silvestres de consumo humano en la aldea Uaxactun, Peten. Revista Científica de la Facultad de Ciencias Químicas y Farmacia 12(1): 5

Ayouba A, Akoua-Koffi C, Calvignac-Spencer S, Esteban A, Locatelli S, Li H, Li Y, Hahn B, Delaporte E, Leendertz FH, Peeters M (2013) Evidence for continuing cross-species transmission of SIVsmm to humans: characterization of a new HIV-2 lineage in rural Côte d'Ivoire. AIDS 27(15):2488-2491

Bachand N, Ravel A, Onanga R, Arsenault J, Gonzalez JP (2012) Public health significance of zoonotic bacterial pathogens from bushmeat sold in urban markets of Gabon, Central Africa. Journal of wildlife diseases 48(3): 785-789

Barros FB, de Aguiar Azevedo P (2014) Common opossum (Didelphis marsupialis Linnaeus, 1758): food and medicine for people in the Amazon. Journal of ethnobiology and ethnomedicine 10(65):1-13

Barros FB, Pereira HM, Vicente L (2011) Use and knowledge of the razor-billed curassow Pauxi tuberosa (spix, 1825) (galliformes, cracidae) by a riverine community of the Oriental Amazonia, Brazil. Journal of Ethnobiology and Ethnomedicine 7(1): 1-11

Beer BE, Bailes E, Goeken R, Dapolito G, Coulibaly C, Norley SG, Kurth R, Gautier JP, Gautier-Hion A, Vallet D, Sharp PM, Hirsch VM (1999) Simian Immunodeficiency Virus (SIV) from Sun-Tailed Monkeys (Cercopithecus solatus): Evidence for Host-Dependent Evolution of SIV within the C. Ihoesti Superspecies. Journal of virology 73(9): 77347744

Begossi A, Braga S (1992) Food taboos and folk medicine among fishermen from the Tocantins River(Brazil). Amazoniana 12(1): 101118

Byron EM (2003) Market integration and health: the impact of markets and acculturation on the self-perceived morbidity, diet, and nutritional status of the Tsimane' Amerindians of lowland Bolivia. Ph.D. Dissertation, University of Florida, Gainesville, USA.

Calattini $S$, Betsem EBA, Froment $A$, Mauclère $P$, Tortevoye P, Schmitt C, Njouom R, Saib A, Gessain A (2007). Simian foamy virus 
transmission from apes to humans, rural Cameroon. Emerging infectious diseases 13(9): 1314-1320

Calvignac S, Adjogoua EV, Akoua-Koffi C, Hedemann C, Schubert G, Ellerbrok H, Leendertz SAJ, Pauli G, Leendertz, F (2012) Origin of Human T-Lymphotropic Virus Type 1 in Rural Côte d'Ivoire. Emerging infectious diseases 18(5):830-833

Camacho Martínez AV (2013) El uso medicinal de la fauna silvestre y sus implicaciones para la conservación en el municipio del Valle del Guamuez, Putumayo, Colombia. Bachelor thesis, Pontificia Universidad Javeriana, Bogotá, Colombia.

Carme B, Bissuel F, Ajzenberg D, Bouyne R, Aznar C, Demar M, Bichat S, Louvel D, Bourbigot AM, Peneau C, Neron P (2002) Severe acquired toxoplasmosis in immunocompetent adult patients in French Guiana. Journal of Clinical Microbiology 40(11): 4037-4044

Cawthorn DM, Hoffman, LC (2015) The bushmeat and food security nexus: a global account of the contributions, conundrums and ethical collisions. Food Research International 76, 906-925.

Chowdhury R, Warnakula S, Kunutsor S, Crowe F, Ward HA, Johnson L, Franco O, Butterworth AS, Forouhi NG, Thompson SG, Khaw KT, Mozaffarian D, Danesh J, Angelantonio E (2014) Association of dietary, circulating, and supplement fatty acids with coronary riska systematic review and meta-analysis. Annals of internal medicine 160(6): 398-406

Chua KB (2003) Nipah virus outbreak in Malaysia. Journal of Clinical Virology 26(3): 265275

CITES (2000) Bushmeat as a trade and wildlife management issue. Eleventh meeting of the Conference of the Parties Gigiri, Kenya. Doc 11.4. Available: https://ecohealth.net/wpcontent/uploads/2016/10/ECH_Author_Info-3.pdf

Clark BM, Murray CK, Horvath LL, Deye GA, Rasnake MS, Longfield RN (2008) Case-control study of armadillo contact and Hansen's disease. The American Journal of Tropical Medicine and Hygene 78: 962-967

Courgnaud V, Abela B, Pourrut X, Mpoudi-Ngole E, Loul S, Delaporte E, Peeters M (2003) Identification of a new simian immunodeficiency virus lineage with a vpu gene present among different cercopithecus monkeys (C. mona, C. cephus, and C. nictitans) from Cameroon. Journal of virology 77(23): 12523-12534

Corbet $S$, Müller-Trutwin $M C$, Versmisse $P$, Delarue S, Ayouba A, Lewis J, Brunak S, Martin $P$, Brun-vezinet $F$, Simon F, Barre-sinoussi $F$, Mauclere $P(2000)$ env sequences of simian immunodeficiency viruses from chimpanzees in Cameroon are strongly related to those of human immunodeficiency virus group $\mathbf{N}$ from the same geographic area. Journal of virology 74(1): 529-534

Costa-Neto EM (2004) Implications and applications of folk zootherapy in the state of Bahia, Northeastern Brazil. Sustainable Development 12(3): 161-174

Coura JR, Junqueira AC, Fernandes O, Valente AS, Miles MA (2002) Emerging chagas disease in Amazonian Brazil. Trends in parasitology 18(4): 171-176

Cuesta-Ríos EY, Valencia-Mazo JD, JiménezOrtega AM (2007) Aprovechamiento de los vertebrados terrestres por una comunidad humana en bosques tropicales (Tutunendo, Chocó, Colombia). Revista Institucional Universidad Tecnológica del Chocó 26(2): 37-43

da Silva AV, Bosco SDMG, Langoni H, Bagagli $E$ (2006) Study of Toxoplasma infection in Brazilian wild mammals: Serological evidence in Dasypus novemcinctus Linnaeus, 1758 and Euphractus sexcinctus Wagler, 1830. Veterinary parasitology 135(1): 81-83

de Thois B, Demar M, Aznar C, Carme B (2003) Ecologic correlates of Toxoplasma gondii exposure in free-ranging neotropical mammals. Journal of wildlife diseases 39(2): 456459

Deps PD, Alves BL, Gripp CG, Aragao RL, Guedes B, Filho JB, Andreatta MK, Marcari RS, Prates I, Rodriguez LC (2008) Contact with armadillos increases the risk of leprosy in Brazil: a case control study. Indian Journal of Dermatology Venereology and Leprology 74: 338342

Dounias E, Froment A (2011) From foraging to farming among present-day forest huntergatherers: consequences on diet and health. International Forestry Review 13(3): 294-304

Elliott SS, Keim NL, Stern JS, Teff K, Havel PJ 
(2002) Fructose, weight gain, and the insulin resistance syndrome. American Journal of Clinical Nutrition 76:911-922

Etienne L, Nerrienet E, LeBreton M, Bibila GT, Foupouapouognigni $Y$, Rousset D, Nana A, Djoko CF, Tamoufe U, Aghokeng AF, Mpoudi-Ngole E, Delaporte E, Peeters M, Wolfe ND, Ayouba A (2011) Characterization of a new simian immunodeficiency virus strain in a naturally infected Pan troglodytes troglodytes chimpanzee with AIDS related symptoms. Retrovirology 8(1): 4

Felix GA (2012) Comportamento alimentar e qualidade de carne de capivara (Hydrochoerus hydrochaeris Linnaeus, 1766) de vida livre, em áreas agrícolas. Doctoral dissertation, Universidade Federal da Grande Dourados, Dourados, Brazil

Ferreira FS, Albuquerque UP, Coutinho HDM, Almeida WDO, Alves RRN (2012) The trade in medicinal animals in northeastern Brazil. Evidence-based Complementary and Alternative Medicine 2012: 1-20

Ferreira FS, Brito SV, Ribeiro SC, Almeida WO, Alves RR (2009) Zootherapeutics utilized by residents of the community Poço Dantas, Crato-CE, Brazil. Journal of Ethnobiology and Ethnomedicine 5(11):1-10

Formenty P, Boesch C, Wyers M, Steiner C, Donati F, Dind F, Walker F, Le Guenno B (1999) Ebola virus outbreak among wild chimpanzees living in a rain forest of Cote d'Ivoire. Journal of Infectious Diseases 179 (1): S120-S126

Frota CC, Lima LN, Rocha Ada S, Suffys PN, Rolim BN, Rodrigues LC, Barreto ML, Kendall C, Kerr LR (2012) Mycobacterium leprae in sixbanded (Euphractus sexcinctus) and ninebanded armadillos (Dasypus novemcinctus) in Northeast Brazil. Memórias do Instituto Oswaldo Cruz 107: 209-213.

Gálvez H, Arbaiza T, Carcelén F, Lucas O (1999) Valor nutritivo de las carnes de sajino (tayassu tajacu), venado colorado (mazama americana), majaz (agouti paca) y motelo (geochelone denticulata). Revista de Investigaciones Veterinarias del Perú 10(1):82-86

Ge XY, Li JL, Yang XL, Chmura AA, Zhu G, Epstein JH, Mazet JK, Wei Zhang BH, Peng C, Zhang $\mathrm{YJ}$, Luo $\mathrm{CH}$, Tan B, Wang $\mathrm{N}$, Zhu $\mathrm{Y}$, Crameri C, Zhang SY, Wang LF, Daszak P, Shi ZL (2013) Isolation and characterization of a bat SARS-like coronavirus that uses the ACE2 receptor. Nature 503(7477): 535-538

Golden CD, Fernald LCH, Brashares JS, Rasolofoniaina BJR, Kremen C (2011) Benefits of wildlife consumption to child nutrition in a biodiversity hotspot. Proceedings of the National Academy of Sciences of the United States of America 108:19653-19656

Guan Y, Zheng BJ, He YQ, Liu XL, Zhuang ZX, Cheung CL, Luo SW, Li PH, Zhang LJ, Guan YJ, Butt KM, Wong KL, Chang KW, Lim W, Shortridge KF, Yuen KY, Peiris JSM, Poon LLM (2003). Isolation and characterization of viruses related to the SARS coronavirus from animals in southern China. Science 302(5643): 276-278.

Haesevelde MMV, Peeters M, Jannes G, Janssens W, Van der groen G., Sharp PM, Saman E (1996) Sequence analysis of a highly divergent HIV-1-related lentivirus isolated from a wild captured chimpanzee. Virology 221(2): 346-350

Hahon N, Kozikowski E (1961) Thermal inactivation studies with variola virus. Journal of bacteriology 81(4): 609

Hamilton CM, Katzer F, Beierschmitt A, Soto E, Innes EA, Kelly PJ (2014) First report of Toxoplasma gondii seroprevalence in wildcaught Caribbean African green monkeys. Parasites vectors $7(1): 1-4$

Hanse R Teron R (2012) Ethnozoological practices among the Karbi tribes in Karbi Anglong district of Assam (India). The Ecoscan 1: $117-120$

Hayman DT, Emmerich P, Yu M, Wang LF, SuuIre $R$, Fooks AR, Cunningham AA, Wood JL (2010) Long-term survival of an urban fruit bat seropositive for Ebola and Lagos bat viruses. PloS one 5(8): 1-3

Hoffman LC, Cawthorn D (2013) Exotic protein sources to meet all needs. Meat science 95(4): 764-771.

Holds G, Pointon A, Lorimer M, Kiermeier A, Raven G, Sumner J (2008) Microbial profiles of carcasses and minced meat from kangaroos processed in South Australia. International journal of food microbiology 123(1): 88-92.

Igene JO, Okoro KI, Ebabhamiegbebho PA, Evivie SE (2015) A study assessing some metal elements contamination levels in grasscutter (Thryonomys swinderianus 
Temminck) meat. International Journal of Biotechnology and Food Science 3(5): 63

Innes EA (2010) A brief history and overview of Toxoplasma gondii. Zoonoses and public health 57(1): 1-7

Jobbins SE, Sanderson CE, Alexander KA (2014) Leptospira interrogans at the human-wildlife interface in northern Botswana: a newly identified public health threat. Zoonoses and public health 61(2): 113-123

Johns T (1996) The origins of human diet and medicine. University of Arizona Press, Tucson, USA.

Kamins AO, Rowcliffe JM, Ntiamoa-Baidu Y, Cunningham AA, Wood JL, Restif O. (2015) Characteristics and risk perceptions of Ghanaians potentially exposed to bat-borne zoonoses through bushmeat. EcoHealth 12(1): 104-120

King U, Furgal C (2014) Is hunting still healthy? Understanding the interrelationships between indigenous participation in land-based practices and human-environmental health. International journal of environmental research and public health 11(6): $5751-5782$

Kurpiers LA, Schulte-Herbrüggen B, Ejotre I, Reeder DAM (2016) Bushmeat and emerging infectious diseases: Lessons from Africa. In: Angelici FM (ed) Problematic wildlife: A cross disciplinary approach, Springer, New York, pp. 507-551

Lau SK, Woo PC, Li KS, Huang Y, Tsoi HW, Wong $\mathrm{BH}$, Wong SS, Leung SY, Chan KH, Yuen, KY (2005) Severe acute respiratory syndrome coronavirus-like virus in Chinese horseshoe bats. Proceedings of the National Academy of Sciences of the United States of America 102(39): 14040-14045

LeBreton M, Prosser AT, Tamoufe U, Sateren W, Mpoudi-Ngole E, Diffo JLD, Burke DS, Wolfe ND (2006) Patterns of bushmeat hunting and perceptions of disease risk among central African communities. Animal Conservation 9(4): 357-363

Leendertz FH, Boesch C, Ellerbrok H, Rietschel W, Couacy-Hymann E, Pauli G (2004) Noninvasive testing reveals a high prevalence of simian T-lymphotropic virus type 1 antibodies in wild adult chimpanzees of the Taï National Park, Côte d'Ivoire. Journal of general virology

\section{5(11): 3305-3312}

Leendertz FH, Ellerbrok H, Boesch C, CouacyHymann E, Mätz-Rensing $\mathrm{K}$, Hakenbeck $\mathrm{R}$, Bergmann C, Abaza P, Junglen S, Moebius Y, Vigilant L, Formenty P, Pauli G (2004a) Anthrax kills wild chimpanzees in a tropical rainforest. Nature 430: 451-452.

Leendertz FH, Yumlu S, Pauli G, Boesch C, Couacy-Hymann E, Vigilant L, Junglen $S$, Schenk S, Ellerbrok H (2006) A new Bacillus anthracis found in wild chimpanzees and a gorilla from West and Central Africa. PLoS Pathogens 2(1): 1-4

Leendertz SAJ, Junglen S, Hedemann C, Goffe A, Calvignac S, Boesch C, Leendertz FH (2010) High prevalence, coinfection rate, and genetic diversity of retroviruses in wild red colobus monkeys (Piliocolobus badius badius) in Tai National Park, Cote d'lvoire. Journal of virology 84(15): 7427-7436

Lemire M, Fillion M, Barbosa F, Guimarães J RD, Mergler D (2010) Elevated levels of selenium in the typical diet of Amazonian riverside populations. Science of the total environment 408(19): 4076-4084

Leroy EM, Telfer P, Kumulungui B, Yaba $P$, Rouquet P, Roques P, González JP, Ksiakez TG, Rollin PE, Nerrienet E (2004) A serological survey of Ebola virus infection in central African nonhuman primates. Journal of Infectious Diseases 190(11): 1895-1899

Leroy EM, Rouquet P, Formenty $\mathrm{P}$, Souquiere S, Kilbourne A, Froment JM, Bermejo M, Smit S, Karesh W, Swanepoel R, Zaki SR (2004a) Multiple Ebola virus transmission events and rapid decline of central African wildlife. Science 303(5656): 387-390

Li W, Shi Z, Yu M, Ren W, Smith C, Epstein JH, Wang $\mathrm{H}$, Crameri $\mathrm{G}$, Hu Z, Zhang $\mathrm{H}$, McEachern J, Field H, Daszak P, Eaton BT, Zhang S, Wang LF (2005). Bats are natural reservoirs of SARS-like coronaviruses. Science 310(5748): 676-679.

Liégeois $F$, Boué $V$, Mouacha $F$, Butel $C$, Ondo $B M$, Pourrut $X$, Leroy $E$, Peeters $M$, Rouet F (2012) New STLV-3 strains and a divergent SIVmus strain identified in non-human primate bushmeat in Gabon. Retrovirology 9(1): 28.

Liégeois $F$, Boué $V$, Butel $C$, Mouinga-Ondémé $A$, Sica J, Zamba C, Peeters M, Delaporte E, Rouet, 
F (2013). HIV type-1 group 0 infection in gabon: Low prevalence rate but circulation of genetically diverse and drug-resistant HIV type-1 group $O$ strains. AIDS research and human retroviruses 29(7): 1085-1090

Liégeois F, Courgnaud V, Switzer WM, Murphy HW, Loul S, Aghokeng A, Pourrut X, MpoudiNgole E, Delaporte E, Peeters M (2006) Molecular characterization of a novel simian immunodeficiency virus lineage (SIVtal) from northern talapoins (Miopithecus ogouensis). Virology 349(1): 55-65

Liégeois F, Lafay B, Formenty $\mathrm{P}$, Locatelli $\mathrm{S}$, Courgnaud V, Delaporte E, Peeters M (2009) Full-length genome characterization of a novel simian immunodeficiency virus lineage (SIVolc) from olive Colobus (Procolobus verus) and new SIVwrcPbb strains from Western Red Colobus (Piliocolobus badius badius) from the Tai Forest in Ivory Coast. Journal of virology 83(1): 428-439

Liégeois F, Lafay B, Switzer WM, Locatelli $S$, Mpoudi-Ngolé E, Loul S, Heneine W, Delaporte E, Peeters M (2008) Identification and molecular characterization of new STLV-1 and STLV-3 strains in wild-caught nonhuman primates in Cameroon. Virology 371(2): 405417.

Liégeois F, Schmidt F, Boué $V$, Butel C, Mouacha $F$, Ngari $P$, Ondo $M$, Leroy $E$, Heeney JL, Delaporte E, Peeters, M Rouet F (2014) Fulllength genome analyses of two new Simian Immunodeficiency Virus (SIV) strains from mustached monkeys (C. Cephus) in Gabon illustrate a complex evolutionary history among the SIVmus/mon/gsn lineage. Viruses 6(7): 2880-2898.

Locatelli S, Lafay B, Liegeois F, Ting N, Delaporte E, Peeters M (2008) Full molecular characterization of a simian immunodeficiency virus, SIVwrcpbt from Temminck's red colobus (Piliocolobus badius temminckii) from Abuko Nature Reserve, The Gambia. Virology 376(1): 90-100

Locatelli S, Liegeois F, Lafay B, Roeder AD, Bruford MW, Formenty P, Noë R, Delaporte E, Peeters M (2008a) Prevalence and genetic diversity of Simian Immunodeficiency Virus infection in wild-living red colobus monkeys (Piliocolobus badius badius) from the Taï forest, Côte d'Ivoire: SIVwrc in wild-living western red colobus monkeys. Infection, Genetics and Evolution 8(1): 1-14
Lord VR, Lord RD (1991) Brucella suis infections in collared peccaries in Venezuela. Journal of Wildlife diseases 27(3): 477-481

Lussac G (2010) Approche écologique, épidémiologique et genetique de la biodiversité de Toxoplasma gondii en zone tropicale humide: exemples du Gabon et de la Guyane Française. PhD Thesis, Université de Limoges, Limoges, France.

Madar CS, Cardile AP, Cunningham S, Magpantay G, Finger D (2012) A case of Salmonella gastroenteritis following ingestion of raw venison sashimi. Hawai'i Journal of Medicine Public Health 71(2): 49-50

Malaisse F, Parent G (1982) Rodents of the Miombo woodland area: a nutritional and ecological approach. Ecology of Food and Nutrition 11(4): 211-216

Mananga $V$, Elenga $M$, Massamba $D$, MakossoVheiye G, Maloumbi MG, Kinkela T (2015) Étude comparée de la biodisponibilité et de la valeur nutritionnelle des triacylglycérols des lipides de l'athérure africain (Atherurus africanus) et du céphalophe bleu (Cephalophus monticola). Bulletin de la Société Royale des Sciences de Liège 84: 14-25

Mander M, Ntuli L, Diederichs N, Mavundla K (2007). Economics of the traditional medicine trade in South Africa: health care delivery. South African health review 189-196

Martinez GJ (2013) Use of fauna in the traditional medicine of native Toba (qom) from the Argentine Gran Chaco region: an ethnozoological and conservationist approach. Ethnobiology and Conservation 2:1-43.

Mayor P, Baquedano LE, Sanchez E, Aramburu J, Gomez-Puerta LA, Mamani VJ Gavidia CM (2015) Polycystic Echinococcosis in Pacas, Amazon Region, Peru. Emerging infectious diseases 21(3): 456

Mbaya AW, Ahmed MI, Ibrahim UI, Lamurde KJ (2010) Trichinellosis in African giant rats (Cicetomycs gambianus) in the arid-region of Northeastern, Nigeria. Journal of Medicine and Medical Sciences 1(10): 460-464

Milner-Gulland E, Bennet EL (2003) Wild meat: the bigger picture. Trends in Ecology and Evolution 18(7): $351-357$

Morales MJ, Villa JT (1998) Notas sobre el uso de fauna silvestre en Catemaco, Veracruz. Acta Zoológica Mexicana 73: 127-143 
Motte-Florac E, Bahuchet S, Thomas JMC (1993) The role of food in the therapeutics of the Aka Pygmies of the Central African Republic. In: Hladik CM, Pagezy H, Linares OF, Hladik A, Semple A, Hadley M (eds) Tropical Forests, People and Food: Biocultural Interactions and Applications to Development, Man and Biosphere Series, Unesco-Parthenon, Paris, pp. 549-560

Mouinga-Ondémé $A$, Caron $M$, Nkoghé $D$, Telfer P, Marx P, Saïb A, Leroy E, Gonzalez JP, Gessain A, Kazanji M (2012) Cross-species transmission of simian foamy virus to humans in rural Gabon, Central Africa. Journal of virology 86(2), 1255-1260

Mouinga-Ondémé A, Kazanji M (2013) Simian foamy virus in non-human primates and cross-species transmission to humans in Gabon: An emerging zoonotic disease in central Africa?. Viruses 5(6):1536-1552

Nasi R, Brown D, Wilkie D, Bennett E, Tutin C, Van Tol G, Christophersen T (2008) Conservation and use of wildlife-based resources: the bushmeat crisis. Secretariat of the Convention on Biological Diversity, Montreal. and Center for International Forestry Research (CIFOR), Bogor. Technical Series 33: 1-50

Nasi R, Taber A, van Vliet N (2011) Empty forests, empty stomachs? Bushmeat and livelihoods in the Congo and Amazon Basins. International Forestry Review 13: 355-368

Ndembi N, Kaptue L. Ido E (2007) Exposure to SIVmnd-2 in southern Cameroon: public health implications. HIV AIDS review 6(3): 16-19

Niyi $\mathrm{OH}$ (2014) Nutritional and functional properties of african wild antelope (Antilocapra americana) meat. American Chemical Science Journal 4(4): 546-553

Okoye IC, Ozioko KU, Obiezue NR, Ikele BC (2015) Intestinal parasitic fauna and zoonotic potentials of commonly consumed wildlife. Helminthologia 52(3): 195-204

Olival KJ, Islam A, Yu M, Anthony SJ, Epstein JH, Khan SA, Khan SU, Crameri G, Wang LF, Lipkin WI, Luby SP, Daszak P (2013) Ebola Virus Antibodies in Fruit Bats, Bangladesh. Emerging Infectious Disease 19 (2): 270-273

Onadeko AB, Egonmwan RI, Saliu JK (2011) Edible amphibian species: local knowledge of their consumption in southwest Nigeria and their nutritional value. West African Journal of
Applied Ecology 19(1)

Oyarekua MA, Ketiku AO (2010) The nutrient composition of the African rat. Advance Journal of Food Science and Technology 2(6): 318-324

Peeters M, Courgnaud V, Abela B, Auzel P, Pourrut X, Bibollet-Ruche F, Loul S, Liegeois F, Butel C, Koulagna D, Mpoudi-Ngole E, Shaw GM, Hahn BH, Delaporte E (2002) Risk to human health from a plethora of simian immunodeficiency viruses in primate bushmeat. Emerging Infectious Diseases 8(5): 451457

Pernet O, Schneider BS, Beaty SM, LeBreton M, Yun TE, Park A, Zachariah T, Bowden TA, Hitchens P, Ramirez CM, Daszak P, Mazet J, Freiberg AN, Wolfe ND, Lee B (2014) Evidence for henipavirus spillover into human populations in Africa. Nature communications 5:1-10

Pinto LCL, Mateus MB, Pires MRS (2012) Conhecimentos e usos da fauna terrestre por moradores rurais da Serra do Ouro Branco, Minas Gerais, Brasil. Interciencia 37(7): 520-527

Pourrut X, Souris M, Towner JS, Rollin PE, Nichol ST, Gonzalez JP, Leroy E (2009) Large serological survey showing cocirculation of Ebola and Marburg viruses in Gabonese bat populations, and a high seroprevalence of both viruses in Rousettus aegyptiacus. BMC infectious diseases 9(1): 159

Pozio E, Pagani P, Marucci G, Zarlenga DS, Hoberg EP, De Meneghi D, La Rosa G, Rossi L (2005) Trichinella britovi etiological agent of sylvatic trichinellosis in the Republic of Guinea (West Africa) and a re-evaluation of geographical distribution for encapsulated species in Africa. International journal for parasitology 35(9): 955-960

Radonić, A, Metzger S, Dabrowski PW, CouacyHymann E., Schuenadel L, Kurth A, MätzRensing K, Boesch C, Leendertz FH, Nitsche A (2014) Fatal monkeypox in wild-living sooty mangabey, Côte d'Ivoire, 2012. Emerging infectious diseases 20(6): 1009-1011

Rasambainarivo FT (2013) Prévalence d'excrétion de Giardia et Cryptosporidium chez les humains, les animaux domestiques et les lémuriens de l'écosystème du Parc National de Ranomafana, Madagascar. Master Dissertation, Université de Montréal, Montreal, Canada. 
Reynolds MG, Carroll DS, Olson VA, Hughes C, Galley J, Likos A, Montgomery JM, Suu-Ire R, Kwasi MO, Jeffrey Root J, Braden Z, Abel J, Clemmons, C. Regnery R, Karem K, Damon IK (2010) A silent enzootic of an orthopoxvirus in Ghana, West Africa: evidence for multispecies involvement in the absence of widespread human disease. The American journal of tropical medicine and hygiene 82(4), 746754

Ripple WJ, Abernethy K, Betts MG, Chapron G, Dirzo R, Galetti M, Levi T, Lindsey PA, MacDonald DW, Machovina B, Newsome TM, Peres CA, Wallach AD, Wolf C, Young H (2016) Bushmeat hunting and extinction risk to the world's mammals. Royal Society Open Science 3(10): 160498.

Roger DD, Justin EJ, Francois-Xavier E (2012) Nutritional properties of "Bush Meals" from North Cameroon's Biodiversity. Advances in Applied Science Research 3: 1482-1493

Samson C, Pretty J (2006) Environmental and health benefits of hunting lifestyles and diets for the Innu of Labrador. Food Policy 31(6): 528553

Sarkis F (2002) Avaliação das condições microbiológicas de carnes de animais silvestres no município de São Paulo. Doctoral dissertation, Universidade de São Paulo, São Paulo, Brasil

Sarti FM, Adams C, Morsello C, van Vliet N, Schör T, Yagüe B, Tellez L, Quiceno MP, Cruz D (2015) Beyond protein intake: bushmeat as source of micronutrients in the Amazon TriFrontier region. Ecology and Society 20(4): 22

Scoones I, Melnyk M, Pretty JN (1992) The Hidden Harvest: Wild Foods and Agricultural Systems. A Literature Review and Annotated Bibliography. International Institute for Environment and Development, London

Sidorowicz J (1974) The effect of fire on small mammal populations in Zambia. Zambia Geographical Association Magazine 27: 18-25

Silva E, Rosa P, Arruda M, Rúbio E (2005) Determination of duffy phenotype of red blood cells in Dasypus novemcinctus and Cabassous sp. Brazilian Journal of Biology 65(3): 555-557

Siren A, Machoa J (2008) Fish, wildlife, and human nutrition in tropical forests: a fat gap? Interciencia 33:186-193
Sirén A (2012) Festival hunting by the kichwa people in the Ecuadorian amazon. Journal of Ethnobiology 32(1): 30-50.

Smith KM, Anthony SJ, Switzer WM, Epstein JH, Seimon T, Jia $H$, Sanchez MD, Huynh TT, Galland GG, Shapiro SE, Sleeman JM, McAloose D, Stuchin M, Amato G, Kolokotronis SO, Lipkin WI, Karesh WB, Daszak P, Marano N (2012) Zoonotic viruses associated with illegally imported wildlife products. PLoS One 7(1)

Smith T, Earland J, Bhatia K, Heywood P, Singleton N (1993) Linear growth of children in Papua New Guinea in relation to dietary, environmental and genetic factors. Ecology of Food and Nutrition 31:1-25

Soares MDCP, Nunes HM, Silveira FAAD, Alves MM, Souza AJSD (2011) Capillaria hepatica (Bancroft, 1893)(Nematoda) entre populações indígenas e mamíferos silvestres no noroeste do Estado do Mato Grosso, Brasil, 2000. Revista Pan-Amazônica de Saúde 2(3): 35-40

Solavan A, Paulmurugan R, Wilsanand V Ranjith, Sing AJA (2004). Traditional therapeutic uses of animals among tribal population of Tamil Nadu. Indian Journal of Traditional Knowledge 3(2), 206-207

Subramanian M (2012) Zoonotic disease risk and the bushmeat trade: assessing awareness among hunters and traders in Sierra Leone. EcoHealth 9(4):471-482

Swanepoel R, Smit S, Rollin PE, Formenty P, Leman PA, Kemp A, Burt FJ, Grobbelaar A, Croft $J$, Bausch DG, Zeller $H$, Leirst $H$, Braack LEO, Libande ML, Sherif R, Stuart T, Thomas G, Janusz T (2007) Studies of reservoir hosts for Marburg virus. Emerging Infectious Diseases 12(13):1847-1851

Tappe D, Sulyok M, Riu T, Rózsa L, Bodó I, Schoen C, Muntau B, Babocsay G, Hardi R (2016) Co-infections in visceral pentastomiasis, Democratic Republic of the Congo. Emerging Infectious Diseases 22(8): 1333-1339

Thomas JMC (1987) Des goûts et des dégoûts chez les Aka, Ngbaka et autres (Centrafrique). In: Koechlin B, Sigaut F, Thomas JMC and Toffin $G$ (eds) De la voûte céleste au terroir, du jardin au foyer, EHESS, Paris, pp. 489-504

Truman R (2008) Armadillos as a source of infection for leprosy. Southern Medical Journal 101: $581-582$ 
Truppel JH, Reifur L, Montiani-Ferreira F, Lange RR, de Castro RG, Gennari SM, Thomaz-Soccol $\checkmark$ (2010) Toxoplasma gondii in Capybara (Hydrochaeris hydrochaeris) antibodies and DNA detected by IFAT and PCR. Parasitology research 107(1):141-146

Tsujimoto H, Hasegawa A, Maki N, Fukasawa M, Miura T, Speidel S, Cooper RW, Moriyama EN, Gojobori T, Hayami M (1989) Sequence of a novel simian immunodeficiency virus from a wild-caught African Mandrill. Nature 341(6242): 539-541

Tsujimoto $\mathrm{H}$, Hasegawa A, Maki N, Fukasawa M, Miura T, Miura T (1989). Sequence of a novel simian immunodeficiency virus from a wildcaught African Mandrill. Nature 341(6242): 539541

Van Borm S, Thomas I, Hanquet I, Lambrecht B Boschmans M, Dupont G, Decaestecker M, Snacken R, van den Berg T (2005) Highly Pathogenic H5N1 Influenza Virus in Smuggled Thai Eagles, Belgium. Emerging Infectious Diseases 11(5): 702-705

van Vliet N Mbazza P (2011) Recognizing the multiple reasons for bushmeat consumption in urban areas: a necessary step toward the sustainable use of wildlife for food in Central Africa. Human Dimensions of Wildlife 16(1): 45-54

van Vliet N, Fa JE Nasi R (2015) Managing hunting under uncertainty: from one-off ecological indicators to resilience approaches in assessing the sustainability of bushmeat hunting. Ecology and Society 20(3)

Vega MG, Carpinetti B, Duarte J, Fa JE (2013) Contrasts in livelihoods and protein intake between commercial and subsistence bushmeat hunters in two villages on Bioko Island, Equatorial Guinea. Conservation Biology 27(3): 576-587

Whitney ES, Beatty ME, Taylor Jr TH, Weyant R, Sobel J, Arduino MJ, Ashford DA (2003) Inactivation of Bacillus anthracis spores. Emerging infectious diseases 9(6): 623-627

Wilkie D, Starkey M, Abernethy K, Nstame E, Telfer P, Godoy R (2005) Role of prices and wealth in consumer demand for bushmeat in Gabon, Central Africa. Conservation Biology 19: 268-274

Wolfe ND, Switzer WM, Carr JK, Bhullar VB, Shanmugam V, Tamoufe U, Prosser, AT, Torimiro JN, Wright A, Mpoudi-Ngole E, McCutchan FE,
Birx DL, Folks TM, Burke DS, Heneine W (2004) Naturally acquired simian retrovirus infections in central African hunters. The Lancet 363(9413): 932-937

Yang D, Dai X, Deng Y, Lu W, Jiang Z (2007) Changes in attitudes toward wildlife and wildlife meats in Hunan Province, central China, before and after the severe acute respiratory syndrome outbreak. Integrative zoology 2(1): 19-25

Yemi OR, Asiru RA, Shokoya DA (2015) Heavy Metals ( $\mathrm{Cd}, \mathrm{Pb}, \mathrm{Cu}, \mathrm{Fe}, \mathrm{Cr}, \mathrm{Mn}, \mathrm{Zn}$ ) Contents in Ungulates of Ogun State Agricultural Farm Settlement, Ago-Iwoye, Nigeria. Journal of Biology and Life Science 6(2): 119-129

Received: 10 March 2017

Accepted: 18 April 2017

Published: 20 April 2017 
오

등

융

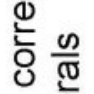

믕 을

$\subseteq$ 뜸

워

동

들 응

क क

잉 믐

돈

음

인

क人 은

닝

뜽 흥

응 힌

\begin{tabular}{|c|c|c|c|c|c|c|c|c|c|c|c|c|}
\hline әวגnos & 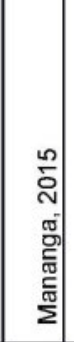 & 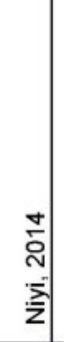 & 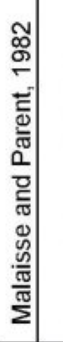 & 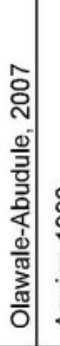 & 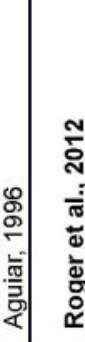 & 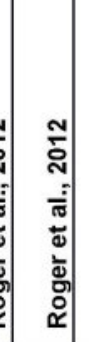 & 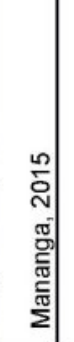 & 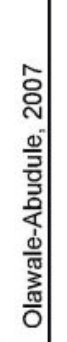 & 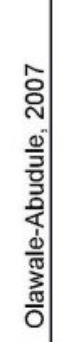 & 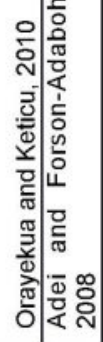 & 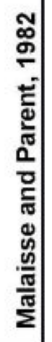 & 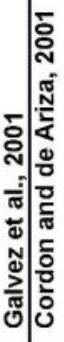 \\
\hline כ00L/6 aגıı!!oW & & \begin{tabular}{l|l|}
$\infty$ & 0 \\
$\infty$ &
\end{tabular} & $\bar{p}$ & $\stackrel{9}{+}$ & 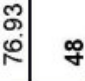 & 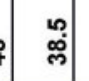 & & 吕 & 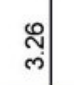 & 它 & $\bar{g}$ & if \\
\hline $500 \mathrm{~L} / 6$ पS $\forall$ & & $\stackrel{\hat{0}}{\dot{+}}$ & $N$ & : & \begin{tabular}{l|l}
\multirow{N}{*}{} \\
¿
\end{tabular} & $\bar{s}$ & & 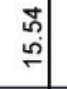 & $\begin{array}{l}0 \\
0 \\
0\end{array}$ & $\sim$ & $\stackrel{\circ}{\mathrm{N}}$ & in $\left[\begin{array}{lll}\infty \\
\infty\end{array}\right.$ \\
\hline 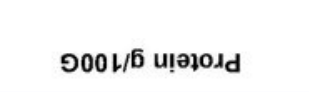 & & $\begin{array}{l}\stackrel{0}{0} \\
\stackrel{+}{\sim}\end{array}$ & $\stackrel{-}{\circ}$ & \begin{tabular}{l}
$\mathfrak{N}$ \\
$\substack{0 \\
\hdashline}$
\end{tabular} & 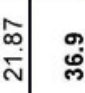 & 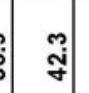 & & : & 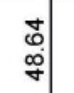 & $\overline{\hat{n}}$ & 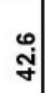 & \& \\
\hline ІЕэ્्र КБдәиэ & & & 위 & & 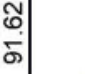 & & & & & & ลี & ลั้ \\
\hline כ00L/Б әدq!త & & १ & & $\stackrel{5}{0}$ & $\check{0}$ & 0 & & $\stackrel{\circ}{\circ}$ & 萬 & & & \\
\hline 000L/6 sp!d!7 & $\stackrel{0}{\mathrm{~N}}$ & స్య & $m$ & $\stackrel{ \pm}{\mathrm{N}}$ & : & \pm & $\stackrel{\circ}{\sim}$ & 离 & 志 & $\stackrel{+}{\rightleftarrows}$ & i & \\
\hline э00 L/6 sәңеגрКчоqлеэ & & సิ & & 心 & $\stackrel{0}{\circ}$ & $\begin{array}{l}0 . \\
\end{array}$ & & 离 & $\stackrel{\mathrm{J}}{\mathrm{N}}$ & - & & \\
\hline (Б00 L/6u) әsәuеБиew & & $\mathrm{z}$ & $\stackrel{m}{\forall}$ & 0 & กี & $n$ & & rio & No & $\stackrel{ }{\circ}$ & $\overline{\mathrm{N}}$ & \\
\hline 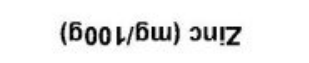 & & ஓ्ల| & & $\stackrel{m}{\oplus}$ & צ & צִ & & $\stackrel{-}{-}$ & $\stackrel{+}{-}$ & 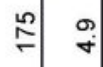 & & + \\
\hline 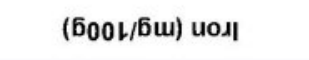 & & siol & $\stackrel{n}{\sim}$ & Бे. & พ & 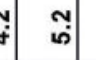 & & iी & $\stackrel{\infty}{\infty}$ & 舟。 & 아 & s \\
\hline (500L/6u) un!pos & & $\bar{\sim}$ & & $\stackrel{\infty}{n}$ & & & & $\bar{\sigma}$ & প্ & & & \\
\hline (600 L/6u) un!̣sauбew & & $\stackrel{2}{2}$ & & go & 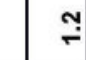 & $\bar{m}$ & & 触 & ญิ & & & $\infty$ \\
\hline (Б00 L/6u) un!̣ગeכ & & $\stackrel{\circ}{\circ}$ & 워 & ô & $\overline{\mathbf{N}}$ & ง. & & 号 & న్ల్ & iी & 암 & 88 \\
\hline (600L/6u) un!sserod & & నิ & 윳 & 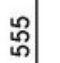 & & & & ‡্ & 응 & 命 & : & 掘 \\
\hline (500L/6u) snuoudsoud & & \& & & & & & & & & 잇 & & هั \\
\hline & 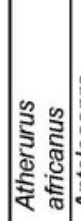 & 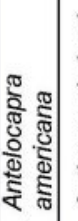 & 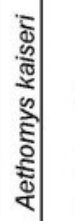 & 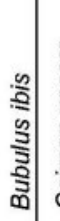 & 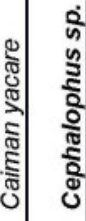 & 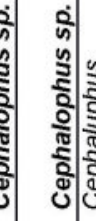 & | & 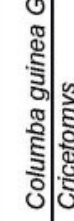 & 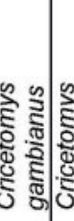 & : है: & 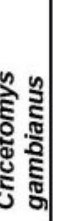 & 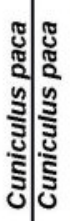 \\
\hline
\end{tabular}

๑.

क능

(1)

ह

으

吹

들 을

ठั

त) ह

을 임

논 을

乙 के

‘

×웛 


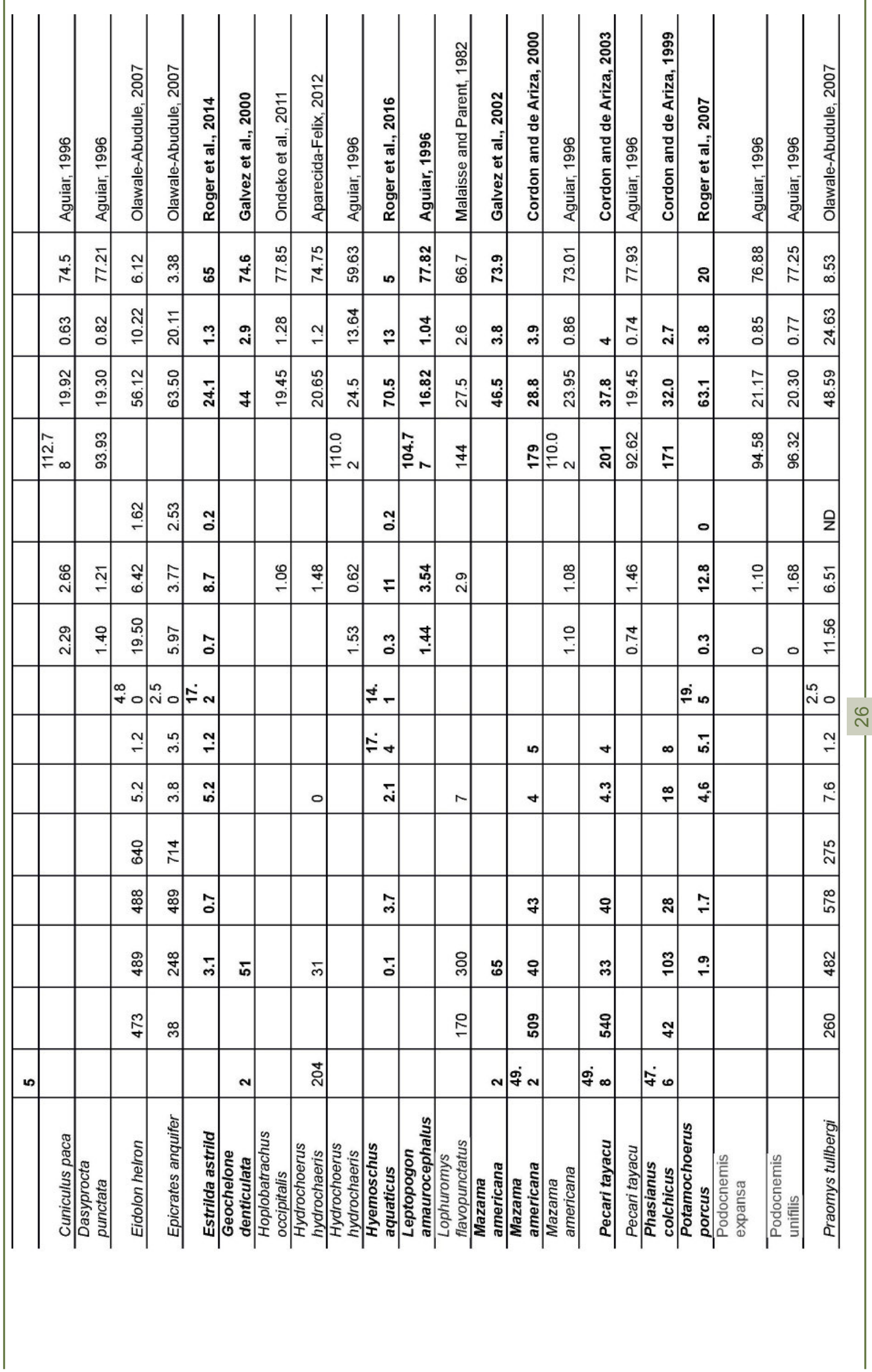




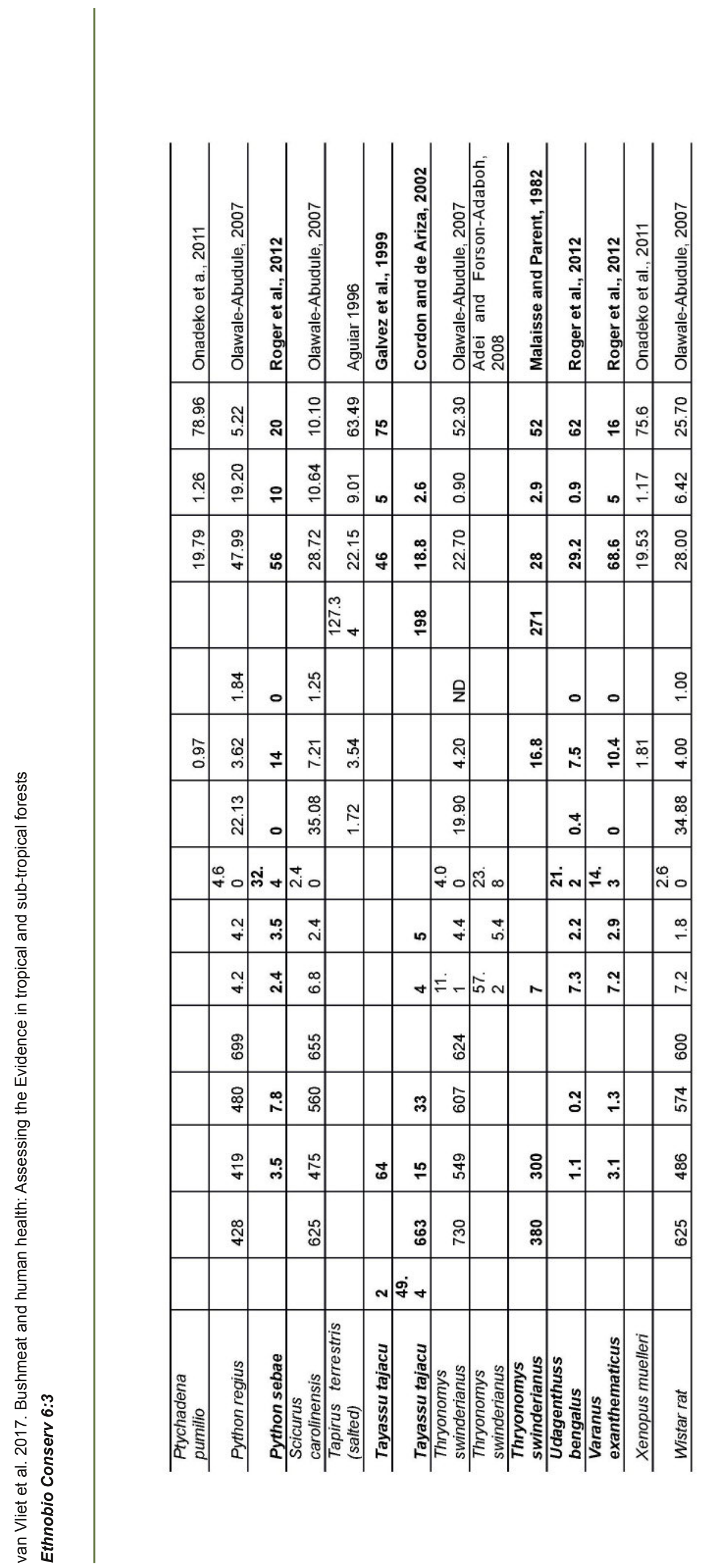




\section{Annex 2. Zootherapeutic uses of bushmeat}

\begin{tabular}{|c|c|c|c|c|c|c|}
\hline Species & $\begin{array}{l}\text { Part of the } \\
\text { animal }\end{array}$ & $\begin{array}{c}\text { Target } \\
\text { population }\end{array}$ & illness cured & $\begin{array}{l}\text { ethnical origin } \\
\text { of the users }\end{array}$ & Country & Source \\
\hline $\begin{array}{l}\text { Achatina achatina } \\
\text { and Achatina } \\
\text { Marginata }\end{array}$ & meat & All population & $\begin{array}{l}\text { Used to cure whooping cough, } \\
\text { aneamia, ulcer, asthma, } \\
\text { hypertension, bone fracture, } \\
\text { infertility in women }\end{array}$ & NA & Nigeria & Agbogidi, 2010 \\
\hline $\begin{array}{l}\text { Atherurus } \\
\text { africanus }\end{array}$ & intestine & All population & Used for stomach ache & Nigerian farmers & Nigeria & Adeola, 1992 \\
\hline $\begin{array}{l}\text { Cephalophus } \\
\text { grimmia }\end{array}$ & Intestine & all population & Stomach ache & Nigerian farmers & Nigeria & Adeola, 1992 \\
\hline Squirrel & whole & children & $\begin{array}{l}\text { Prevention for convulsion in } \\
\text { children }\end{array}$ & Nigerian farmers & Nigeria & Adeola, 1992 \\
\hline Python & fat & All population & Ingredient to cure rheumatism & Nigerian farmers & Nigeria & Adeola, 1992 \\
\hline $\begin{array}{l}\text { Crocodilus } \\
\text { niloticus }\end{array}$ & Intestine & all population & Prevention against poison & Nigerian farmers & Nigeria & Adeola, 1992 \\
\hline Gorilla gorrilla & penis & All population & $\begin{array}{l}\text { Drug for prevention against } \\
\text { poison }\end{array}$ & Nigerian farmers & Nigeria & Adeola, 1992 \\
\hline Manis tricuspis & head & All population & Use in stopping bleeding & Nigerian farmers & Nigeria & Adeola, 1992 \\
\hline $\begin{array}{l}\text { Phacochoerus } \\
\text { africanus }\end{array}$ & legs & All population & Prevention of lameness & Nigerian farmers & Nigeria & Adeola, 1992 \\
\hline Kinixys belliana & Whole & all population & Chest pain & Nigerian farmers & Nigeria & Adeola, 1992 \\
\hline Agouti paca & penis & All population & Sexual impotence & $\begin{array}{l}\text { Afrodescendant } \\
\mathrm{s}\end{array}$ & Brazil & $\begin{array}{l}\text { Ferreira et al., } \\
2012\end{array}$ \\
\hline \multirow[b]{2}{*}{ Boa constrictor } & fat & All population & Rheumatism, backache & NA & Brazil & $\begin{array}{l}\text { Alves et al., } \\
2010\end{array}$ \\
\hline & $\begin{array}{l}\text { Skin, tail, } \\
\text { head, fat }\end{array}$ & All population & $\begin{array}{l}\text { Asthma, ulcer, stomach ache, } \\
\text { infection, crysipelas, } \\
\text { inflammation, rheumatism, } \\
\text { luxation, diabetes, heart disease, } \\
\text { leprosy }\end{array}$ & $\begin{array}{l}\text { Afrodescendant } \\
\mathrm{s}\end{array}$ & Brazil & $\begin{array}{l}\text { Alves and Filho, } \\
2006\end{array}$ \\
\hline Bothrops sp. & fat & All population & $\begin{array}{l}\text { Rheumatism, pain relief in } \\
\text { injuries caused by sting of insect } \\
\text { or snkae bites }\end{array}$ & $\begin{array}{l}\text { Afrodescendant } \\
\mathrm{s}\end{array}$ & Brazil & $\begin{array}{l}\text { Alves and Filho, } \\
2006\end{array}$ \\
\hline \multirow{2}{*}{$\begin{array}{l}\text { Bradypus } \\
\text { variegatus }\end{array}$} & $\begin{array}{l}\text { Claw, skin, } \\
\text { bones }\end{array}$ & All population & Asthma & NA & Brazil & $\begin{array}{l}\text { Alves et al., } \\
2009\end{array}$ \\
\hline & $\begin{array}{l}\text { Leather, } \\
\text { fat }\end{array}$ & All population & Ulcer, asthma & NA & Brazil & $\begin{array}{l}\text { Alves et al., } \\
2010\end{array}$ \\
\hline \multirow{2}{*}{$\begin{array}{l}\text { Caiman corcodilus } \\
\text { acutus }\end{array}$} & skin & All population & Asthma, allergies, epilepsy & NA & Brazil & $\begin{array}{l}\text { Alves et al., } \\
2009\end{array}$ \\
\hline & fat & All population & Asthma & $\begin{array}{l}\text { Afro- } \\
\text { descendants }\end{array}$ & Colombia & $\begin{array}{l}\text { Cuesta-Rios, } \\
2007\end{array}$ \\
\hline Callithrix sp. & meat & NA & Asthma & NA & Brazil & $\begin{array}{l}\text { Alves and Rosa, } \\
2007\end{array}$ \\
\hline Cathartes sp. & meat & NA & Tuberculosis & NA & Brazil & $\begin{array}{l}\text { Costa-Neto, } \\
2004\end{array}$ \\
\hline Caudison durissa & $\begin{array}{l}\text { Fat, rattle, } \\
\text { bone, skin }\end{array}$ & All population & $\begin{array}{l}\text { Asthma, sore throat, earache, } \\
\text { toothache, cough, bronchitis, } \\
\text { snake bites, stroke, muscular } \\
\text { pain, epilepsy, cancer, } \\
\text { tuberculosis }\end{array}$ & $\begin{array}{l}\text { Afrodescendant } \\
\mathrm{s}\end{array}$ & Brazil & $\begin{array}{l}\text { Ferreira et al., } \\
2012\end{array}$ \\
\hline Cayman latirostris & $\begin{array}{l}\text { Leather, } \\
\text { fat }\end{array}$ & All population & Asthma, thrombosis, rheumatism & NA & Brazil & $\begin{array}{l}\text { Alves et al., } \\
2010\end{array}$ \\
\hline Cerdocyon thous & $\begin{array}{l}\text { Fat and } \\
\text { liver }\end{array}$ & All population & Rheumatism and bronchitis & NA & Brazil & $\begin{array}{l}\text { Ferreira et al., } \\
2009\end{array}$ \\
\hline
\end{tabular}


van Vliet et al. 2017. Bushmeat and human health: Assessing the Evidence in tropical and sub-tropical forests

Ethnobio Conserv 6:3

\begin{tabular}{|c|c|c|c|c|c|c|}
\hline & Fat, bone & All population & Earache, asthmatic bronchitis & NA & Brazil & $\begin{array}{l}\text { Alves et al., } \\
2010\end{array}$ \\
\hline & fat & All population & $\begin{array}{l}\text { Snake bites, sore throat, } \\
\text { rheumatism }\end{array}$ & $\begin{array}{l}\text { Afrodescendant } \\
\mathrm{s}\end{array}$ & Brazil & $\begin{array}{l}\text { Ferreira et al., } \\
2012\end{array}$ \\
\hline Chelonia mydas & fat & All population & $\begin{array}{l}\text { Asthma, arthritis, backache, } \\
\text { stroke, eryspelas, stomach ache }\end{array}$ & $\begin{array}{l}\text { Afrodescendant } \\
\mathrm{s}\end{array}$ & Brazil & $\begin{array}{l}\text { Ferreira et al., } \\
2012\end{array}$ \\
\hline Chelonoides sp. & fat & All population & $\begin{array}{l}\text { Sore throat cough, asthma, } \\
\text { backache, inflammations }\end{array}$ & $\begin{array}{l}\text { Afrodescendant } \\
\mathrm{s}\end{array}$ & Brazil & $\begin{array}{l}\text { Ferreira et al., } \\
2012\end{array}$ \\
\hline $\begin{array}{l}\text { Chelonoidis } \\
\text { denticulata }\end{array}$ & $\begin{array}{l}\text { Whole } \\
\text { animal }\end{array}$ & All population & Hemorrhage & NA & Brazil & $\begin{array}{l}\text { Alves et al., } \\
2009\end{array}$ \\
\hline Civectis civetta & anus & All population & Prevention against convulsions & Nigerian farmers & Nigeria & Adeola, 1992 \\
\hline $\begin{array}{l}\text { Cnemidophorus } \\
\text { ocellifer }\end{array}$ & $\begin{array}{l}\text { Whole } \\
\text { animal }\end{array}$ & All population & $\begin{array}{l}\text { Stroke, thrmbosis, cancer, } \\
\text { hemorrhoids }\end{array}$ & $\begin{array}{l}\text { Afrodescendant } \\
\mathrm{s}\end{array}$ & Brazil & $\begin{array}{l}\text { Ferreira et al., } \\
2012\end{array}$ \\
\hline \multirow{3}{*}{$\begin{array}{l}\text { Coendou } \\
\text { prehensilis }\end{array}$} & spine & All population & Asthma and stroke & NA & Brazil & $\begin{array}{l}\text { Alves et al., } \\
2009\end{array}$ \\
\hline & spine & All population & Ulcer, asthma & NA & Brazil & $\begin{array}{l}\text { Alves et al., } \\
2010\end{array}$ \\
\hline & spine & All population & $\begin{array}{l}\text { Asthma, bronchitis, cough, } \\
\text { thrombosis, cancer, eczema, } \\
\text { acne, toothache, stroke, earache }\end{array}$ & $\begin{array}{l}\text { Afrodescendant } \\
\mathrm{s}\end{array}$ & Brazil & $\begin{array}{l}\text { Ferreira et al., } \\
2012\end{array}$ \\
\hline \multirow{2}{*}{$\begin{array}{l}\text { Conepatus } \\
\text { semistriatus }\end{array}$} & meat & All population & Acne & NA & Mexico & $\begin{array}{l}\text { Morales-Mavíl } \\
\text { and Villa- } \\
\text { Cañedo,1998 }\end{array}$ \\
\hline & Bones & All population & Cough and osteoporosis & NA & Brazil & $\begin{array}{l}\text { Alves et al., } \\
2009\end{array}$ \\
\hline \multirow{2}{*}{ Coragyps atratus } & $\begin{array}{l}\text { Meat and } \\
\text { whole } \\
\text { animal }\end{array}$ & All population & Asthma, cought and alcoholism & NA & Brazil & $\begin{array}{l}\text { Ferreira et al., } \\
2009\end{array}$ \\
\hline & liver & All population & alcoholism & NA & Brazil & $\begin{array}{l}\text { Alves et al., } \\
2009\end{array}$ \\
\hline Coralus canirus & $\begin{array}{l}\text { Whole } \\
\text { animal }\end{array}$ & All population & $\begin{array}{l}\text { Pain, relief in injures caused by } \\
\text { sting of insect and snake bites }\end{array}$ & $\begin{array}{l}\text { Afrodescendant } \\
\mathrm{s}\end{array}$ & Brazil & $\begin{array}{l}\text { Alves and Filho, } \\
2006\end{array}$ \\
\hline \multirow{6}{*}{ Crotalus durissus } & meat & All population & Against cancer & NA & Mexico & $\begin{array}{l}\text { Morales-Mavíl } \\
\text { and Villa- } \\
\text { Cañedo,1998 }\end{array}$ \\
\hline & meat & NA & Rheumatism & NA & Brazil & $\begin{array}{l}\text { Costa-Neto, } \\
2004\end{array}$ \\
\hline & fat & All population & $\begin{array}{l}\text { Snake bites, bruises, } \\
\text { rheumatism, inflammations, } \\
\text { arthritis, alleviate tremor }\end{array}$ & NA & Brazil & $\begin{array}{l}\text { Ferreira et al., } \\
2009\end{array}$ \\
\hline & $\begin{array}{l}\text { Fat, skin, } \\
\text { rattle, } \\
\text { head, eye }\end{array}$ & All population & $\begin{array}{l}\text { Gastritis, rheumatism, spine, } \\
\text { kidney disease, swelling, } \\
\text { asthma, cancer, osteoporosis, } \\
\text { boils,thrombosis }\end{array}$ & $\begin{array}{l}\text { Afrodescendant } \\
\mathrm{s}\end{array}$ & Brazil & $\begin{array}{l}\text { Alves and Filho, } \\
2006\end{array}$ \\
\hline & $\begin{array}{l}\text { Rattle and } \\
\text { fat }\end{array}$ & All population & $\begin{array}{l}\text { Epilepsy, backache, asthma, } \\
\text { osteoporosis, arthritis, variocele, } \\
\text { edema, earache }\end{array}$ & NA & Brazil & $\begin{array}{l}\text { Alves et al., } \\
2009\end{array}$ \\
\hline & $\begin{array}{l}\text { fat, leather } \\
\text { oil }\end{array}$ & All population & Rheumatism, backache & NA & Brazil & $\begin{array}{l}\text { Alves et al., } \\
2010\end{array}$ \\
\hline Cuniculus paca & bill & All population & Analgesic & $\begin{array}{l}\text { Afro- } \\
\text { descendants }\end{array}$ & Colombia & $\begin{array}{l}\text { Cuesta-Rios, } \\
2007\end{array}$ \\
\hline \multirow{3}{*}{$\begin{array}{c}\text { Dasypus } \\
\text { novemcinctus }\end{array}$} & $\begin{array}{l}\text { Fat meat } \\
\text { and tail }\end{array}$ & All population & $\begin{array}{l}\text { Rheumatism, burns, } \\
\text { inflammmations, pain in bones, } \\
\text { ear aches and deafness }\end{array}$ & NA & Brazil & $\begin{array}{l}\text { Ferreira et al., } \\
2009\end{array}$ \\
\hline & $\begin{array}{l}\text { Paw, tail, } \\
\text { fat, skin }\end{array}$ & All population & $\begin{array}{l}\text { Asthma, headache, inflammation } \\
\text { and stomach ache }\end{array}$ & NA & Brazil & $\begin{array}{l}\text { Alves et al., } \\
2009\end{array}$ \\
\hline & Fat and tail & All population & $\begin{array}{l}\text { Deafness, earache, asthma, } \\
\text { burns, sinusitis, cough, pain, } \\
\text { inflammation, urinary infection, } \\
\text { strain, rheumatism }\end{array}$ & $\begin{array}{l}\text { Afrodescendant } \\
\mathrm{s}\end{array}$ & Brazil & $\begin{array}{l}\text { Ferreira et al., } \\
2012\end{array}$ \\
\hline $\begin{array}{l}\text { Desmodus } \\
\text { rotundus }\end{array}$ & $\begin{array}{l}\text { Whole } \\
\text { animal }\end{array}$ & All population & Asthma, stroke, rheumatism & $\begin{array}{l}\text { Afrodescendant } \\
\mathrm{s}\end{array}$ & Brazil & $\begin{array}{l}\text { Ferreira et al., } \\
2012\end{array}$ \\
\hline
\end{tabular}


van Vliet et al. 2017. Bushmeat and human health: Assessing the Evidence in tropical and sub-tropical forests

Ethnobio Conserv 6:3

\begin{tabular}{|c|c|c|c|c|c|c|}
\hline \multirow{2}{*}{$\begin{array}{l}\text { Didelphis } \\
\text { albiventris }\end{array}$} & bones & All population & Cough and osteoporosis & NA & Brazil & $\begin{array}{l}\text { Alves et al., } \\
2009\end{array}$ \\
\hline & Fat & All population & Inguinal bubo, furuncles & NA & Brazil & $\begin{array}{l}\text { Alves et al., } \\
2010\end{array}$ \\
\hline \multirow{3}{*}{$\begin{array}{l}\text { Didelphis } \\
\text { Marsupialis }\end{array}$} & meat & All population & $\begin{array}{l}\text { rheumatism, asthma, sore throat, } \\
\text { and inflammation }\end{array}$ & NA & Brazil & $\begin{array}{l}\text { Barros and } \\
\text { Azevedo, } 2014\end{array}$ \\
\hline & Whole & all population & acne and blood purification & Cofanes & Colombia & $\begin{array}{l}\text { Camacho- } \\
\text { Martínez, } 2013\end{array}$ \\
\hline & liver & women & Hormonal stimulant to give birth & $\begin{array}{l}\text { Afro- } \\
\text { descendants }\end{array}$ & Colombia & $\begin{array}{l}\text { Cuesta-Rios, } \\
2007\end{array}$ \\
\hline $\begin{array}{l}\text { Didelphis } \\
\text { virginicana }\end{array}$ & meat & All population & $\begin{array}{l}\text { To cure skin problems and } \\
\text { anemia }\end{array}$ & NA & Mexico & $\begin{array}{l}\text { Morales-Mavíl } \\
\text { and Villa- } \\
\text { Cañedo,1998 } \\
\end{array}$ \\
\hline \multirow{3}{*}{ Epicrates cenchria } & fat & All population & Rheumatism, sore throat & $\begin{array}{l}\text { Afrodescendant } \\
\mathrm{S}\end{array}$ & Brazil & $\begin{array}{l}\text { Alves and Filho, } \\
2006\end{array}$ \\
\hline & fat & All population & $\begin{array}{l}\text { Sore throat, rheumatism, } \\
\text { swelling, backache, arthrosis, } \\
\text { burns, and toothache }\end{array}$ & $\begin{array}{l}\text { Afrodescendant } \\
\mathrm{s}\end{array}$ & Brazil & $\begin{array}{l}\text { Ferreira et al., } \\
2012\end{array}$ \\
\hline & Fat & All population & Rheumatism & NA & Brazil & $\begin{array}{l}\text { Alves et al., } \\
2010\end{array}$ \\
\hline \multirow{2}{*}{ Eunectes murinus } & fat & All population & $\begin{array}{l}\text { Rheumatism, infection, } \\
\text { erysipelas, inflammation, } \\
\text { asthma, thrombosis }\end{array}$ & $\begin{array}{l}\text { Afrodescendant } \\
\mathrm{s}\end{array}$ & Brazil & $\begin{array}{l}\text { Alves and Filho, } \\
2006\end{array}$ \\
\hline & fat & All population & Erysipelas & NA & Brazil & $\begin{array}{l}\text { Alves et al., } \\
2009\end{array}$ \\
\hline \multirow{3}{*}{$\begin{array}{l}\text { Euphractus } \\
\text { sexcinctus }\end{array}$} & $\begin{array}{l}\text { Fat, meat } \\
\text { and tail }\end{array}$ & All population & $\begin{array}{l}\text { Rheumatism, burns, } \\
\text { inflammmations, pain in bones, } \\
\text { ear aches and deafness }\end{array}$ & NA & Brazil & $\begin{array}{l}\text { Ferreira et al., } \\
2009\end{array}$ \\
\hline & $\begin{array}{l}\text { Fat, skin, } \\
\text { tail, paw }\end{array}$ & All population & $\begin{array}{l}\text { Arthritis, asthma, stroke, loss of } \\
\text { hearing, headache }\end{array}$ & NA & Brazil & $\begin{array}{l}\text { Alves et al., } \\
2009\end{array}$ \\
\hline & $\begin{array}{l}\text { Fat, tail, } \\
\text { and legs }\end{array}$ & All population & $\begin{array}{l}\text { Deafness, earache, asthma, } \\
\text { burns, sinusitis, cough, pains, } \\
\text { inflammations,rheumatism, } \\
\text { sexual impotence, tuberculosis, } \\
\text { infections, and osteoporosis }\end{array}$ & $\begin{array}{l}\text { Afrodescendant } \\
\mathrm{s}\end{array}$ & Brazil & $\begin{array}{l}\text { Ferreira et al., } \\
2012\end{array}$ \\
\hline $\begin{array}{l}\text { Hoplomys } \\
\text { gymnurus }\end{array}$ & liver & Women & Hormonal stimulant to give birth & $\begin{array}{l}\text { Afro- } \\
\text { descendants }\end{array}$ & Colombia & $\begin{array}{l}\text { Cuesta-Rios, } \\
2007\end{array}$ \\
\hline \multirow{3}{*}{ Iguana iguana } & fat & All population & $\begin{array}{l}\text { Ear aches, score throat and } \\
\text { inflammations }\end{array}$ & NA & Brazil & $\begin{array}{l}\text { Ferreira et al., } \\
2009\end{array}$ \\
\hline & Fat and tail & All population & $\begin{array}{l}\text { Earache, deafness, sore throat, } \\
\text { inflammations, swelling }\end{array}$ & $\begin{array}{l}\text { Afrodescendant } \\
\mathrm{s}\end{array}$ & Brazil & $\begin{array}{l}\text { Ferreira et al., } \\
2012\end{array}$ \\
\hline & fat & All population & Festering inflamation & NA & Brazil & $\begin{array}{l}\text { Alves et al., } \\
2010\end{array}$ \\
\hline Lacheris muta & fat & All population & Rheumatism & $\begin{array}{l}\text { Afrodescendant } \\
\mathrm{s}\end{array}$ & Brazil & $\begin{array}{l}\text { Alves and Filho, } \\
2006\end{array}$ \\
\hline $\begin{array}{l}\text { Leopardus } \\
\text { pardalis }\end{array}$ & eyes & All population & Asthma, sexual impotence & $\begin{array}{l}\text { Afrodescendant } \\
\mathrm{s}\end{array}$ & Brazil & $\begin{array}{l}\text { Ferreira et al., } \\
2012\end{array}$ \\
\hline \multirow{2}{*}{$\begin{array}{l}\text { Leptodactylus } \\
\text { labyrinthicus }\end{array}$} & fat & All population & $\begin{array}{l}\text { Sore throat, cough asthma, } \\
\text { arthritis, backache }\end{array}$ & $\begin{array}{l}\text { Afrodescendant } \\
\mathrm{s}\end{array}$ & Brazil & $\begin{array}{l}\text { Ferreira et al., } \\
2012\end{array}$ \\
\hline & fat & All population & Score throat & NA & Brazil & $\begin{array}{l}\text { Ferreira et al., } \\
2009\end{array}$ \\
\hline $\begin{array}{l}\text { Leptodactylus } \\
\text { vastus }\end{array}$ & fat & All population & $\begin{array}{l}\text { Sore throat, cough, asthma, } \\
\text { arthritis, backache }\end{array}$ & $\begin{array}{l}\text { Afrodescendant } \\
\mathrm{s}\end{array}$ & Brazil & $\begin{array}{l}\text { Ferreira et al., } \\
2012\end{array}$ \\
\hline $\begin{array}{l}\text { Leptophis } \\
\text { ahaetula }\end{array}$ & whole & All population & $\begin{array}{l}\text { Pain relief in injuries caused by } \\
\text { sting of insect or snkae bites }\end{array}$ & $\begin{array}{l}\text { Afrodescendant } \\
\mathrm{s}\end{array}$ & Brazil & $\begin{array}{l}\text { Alves and Filho, } \\
2006\end{array}$ \\
\hline $\begin{array}{c}\text { Mazama } \\
\text { americana }\end{array}$ & Tibia & All population & Asthma & NA & Brazil & $\begin{array}{l}\text { Alves et al., } \\
2010\end{array}$ \\
\hline $\begin{array}{l}\text { Mazama } \\
\text { gouazoubira }\end{array}$ & Tail, tibia & All population & $\begin{array}{l}\text { Asthma, sore throat, } \\
\text { rheumatism, arthritis }\end{array}$ & $\begin{array}{l}\text { Afrodescendant } \\
\mathrm{s}\end{array}$ & Brazil & $\begin{array}{l}\text { Ferreira et al., } \\
2012\end{array}$ \\
\hline $\begin{array}{l}\text { Metachirus } \\
\text { nudicaudatus }\end{array}$ & liver & women & Hormonal stimulant to give birth & $\begin{array}{l}\text { Afro- } \\
\text { descendants }\end{array}$ & Colombia & $\begin{array}{l}\text { Cuesta-Rios, } \\
2007\end{array}$ \\
\hline
\end{tabular}


van Vliet et al. 2017. Bushmeat and human health: Assessing the Evidence in tropical and sub-tropical forests

Ethnobio Conserv 6:3

\begin{tabular}{|c|c|c|c|c|c|c|}
\hline Micrurus ibiboboca & fat & All population & $\begin{array}{l}\text { Rheumatism, asthma, toothache, } \\
\text { sore throat, cough, osteoporosis, } \\
\text { swelling, inflammations, arthritis }\end{array}$ & $\begin{array}{l}\text { Afrodescendant } \\
\mathrm{s}\end{array}$ & Brazil & $\begin{array}{l}\text { Ferreira et al., } \\
2012\end{array}$ \\
\hline Micrurus sp. & Whole, fat & All population & $\begin{array}{l}\text { Rheumatism, sting of the snakes } \\
\text { and insects }\end{array}$ & $\begin{array}{l}\text { Afrodescendant } \\
\mathrm{s}\end{array}$ & Brazil & $\begin{array}{l}\text { Alves and Filho, } \\
2006\end{array}$ \\
\hline $\begin{array}{l}\text { Myrmecophaga } \\
\text { tridactyla }\end{array}$ & skin & All population & Stroke & $\begin{array}{l}\text { Afrodescendant } \\
\mathrm{s}\end{array}$ & Brazil & $\begin{array}{l}\text { Ferreira et al., } \\
2012\end{array}$ \\
\hline \multirow{2}{*}{$\begin{array}{l}\text { Oxyrhopus } \\
\text { trigeminus }\end{array}$} & whole & All population & Sting of the snakes and insects & $\begin{array}{l}\text { Afrodescendant } \\
\mathrm{s}\end{array}$ & Brazil & $\begin{array}{l}\text { Alves and Filho, } \\
2006\end{array}$ \\
\hline & fat & All population & Asthma, thrombosis, rheumatism & NA & Brazil & $\begin{array}{l}\text { Alves et al., } \\
2010\end{array}$ \\
\hline $\begin{array}{l}\text { Paleosuchus } \\
\text { palpebrosus }\end{array}$ & leather, fat & All population & Asthma, thrombosis, rheumatism & NA & Brazil & $\begin{array}{l}\text { Alves et al., } \\
2010\end{array}$ \\
\hline \multirow{3}{*}{ Pauxi tuberosa } & bill & All population & Insect or snake bite & $\begin{array}{l}\text { Colono and } \\
\text { ingenous } \\
\text { population }\end{array}$ & Brazil & $\begin{array}{l}\text { Barros et al., } \\
2011\end{array}$ \\
\hline & gizzard & All population & $\begin{array}{l}\text { Pneumonia, bleeding, } \\
\text { indigestion, stroke }\end{array}$ & $\begin{array}{l}\text { Colono and } \\
\text { ingenous } \\
\text { population }\end{array}$ & Brazil & $\begin{array}{l}\text { Barros et al., } \\
2011\end{array}$ \\
\hline & gizzard & children & Cure the lack of appetite & $\begin{array}{l}\text { Colono and } \\
\text { ingenous } \\
\text { population }\end{array}$ & Brazil & $\begin{array}{l}\text { Barros et al., } \\
2011\end{array}$ \\
\hline Philodryas olfersii & $\begin{array}{l}\text { Whole } \\
\text { animal }\end{array}$ & All population & Stroke & $\begin{array}{l}\text { Afrodescendant } \\
\mathrm{s}\end{array}$ & Brazil & $\begin{array}{l}\text { Ferreira et al., } \\
2012\end{array}$ \\
\hline \multirow{2}{*}{$\begin{array}{l}\text { Phrynops } \\
\text { geoffroanus }\end{array}$} & fat & All population & $\begin{array}{l}\text { Erysipelas, arthrities, } \\
\text { rheumatism, eczemas, skin } \\
\text { problems, bruises }\end{array}$ & NA & Brazil & $\begin{array}{l}\text { Alves et al., } \\
2009\end{array}$ \\
\hline & fat, hoof & All population & $\begin{array}{l}\text { Vitiligo, asthma, earache, } \\
\text { tonsillitis }\end{array}$ & NA & Brazil & $\begin{array}{l}\text { Alves et al., } \\
2010\end{array}$ \\
\hline $\begin{array}{l}\text { Phrynops } \\
\text { tuberosus }\end{array}$ & $\begin{array}{l}\text { Fat and } \\
\text { blood }\end{array}$ & All population & $\begin{array}{l}\text { Score throat, rheumatism, } \\
\text { inflammations, asthma }\end{array}$ & NA & Brazil & $\begin{array}{l}\text { Ferreira et al., } \\
2009\end{array}$ \\
\hline $\begin{array}{l}\text { Podocnemis } \\
\text { expansa }\end{array}$ & fat & All population & $\begin{array}{l}\text { Fat is mostly used externally but } \\
\text { also consumed to cure diversity } \\
\text { of illnesses }\end{array}$ & NA & Brazil & $\begin{array}{l}\text { Alves and } \\
\text { Santana, } 2008\end{array}$ \\
\hline $\begin{array}{l}\text { Proechimys } \\
\text { semispinosus }\end{array}$ & liver & women & Hormonal stimulant to give birth & $\begin{array}{l}\text { Afro- } \\
\text { descendants }\end{array}$ & Colombia & $\begin{array}{l}\text { Cuesta-Rios, } \\
2007\end{array}$ \\
\hline \multirow{3}{*}{ Cavia porcellus } & Whole & all population & $\begin{array}{l}\text { stress, cold, weakness of the } \\
\text { brain and headache }\end{array}$ & Pastos & Colombia & $\begin{array}{l}\text { Camacho- } \\
\text { Martínez, } 2013\end{array}$ \\
\hline & Whole & women & weakening of the matrix & Pastos & Colombia & $\begin{array}{l}\text { Camacho- } \\
\text { Martínez, } 2013\end{array}$ \\
\hline & Whole & children & avoid excessive salivary flow & Pastos & Colombia & $\begin{array}{l}\text { Camacho- } \\
\text { Martínez, } 2013\end{array}$ \\
\hline Progne chalybea & $\begin{array}{l}\text { Whole } \\
\text { animal }\end{array}$ & All population & Alcoholism & NA & Brazil & $\begin{array}{l}\text { Ferreira et al., } \\
2009\end{array}$ \\
\hline Pteropus medius & meat & All population & Join pain & $\begin{array}{l}\text { Karbi, Dimasa, } \\
\text { Bodo, } \\
\text { Assamese, } \\
\text { Bengoli, Nepali, } \\
\text { Kuki, Garo }\end{array}$ & India & $\begin{array}{l}\text { Hanse and } \\
\text { Teron, } 2012\end{array}$ \\
\hline Rhea americana & fat & All population & Cough & NA & Brazil & $\begin{array}{l}\text { Alves et al., } \\
2010\end{array}$ \\
\hline \multirow[b]{2}{*}{ Rhinella jimi } & fat & All population & Bruises, inflammations, arthritis & NA & Brazil & $\begin{array}{l}\text { Ferreira et al., } \\
2009\end{array}$ \\
\hline & $\begin{array}{l}\text { Skin and } \\
\text { fat }\end{array}$ & All population & $\begin{array}{l}\text { Sore throat, asthma, flu, cough, } \\
\text { rheumatism, inflammation, } \\
\text { backache, osteoporosis, } \\
\text { arthrosis, arthritis, diarrhea, } \\
\text { toothach, infections, earache }\end{array}$ & & Brazil & $\begin{array}{l}\text { Ferreira et al., } \\
2012\end{array}$ \\
\hline \multirow{2}{*}{ Spilotes pullatus } & whole & All population & $\begin{array}{l}\text { Pain relief in injuries caused by } \\
\text { sting of insect or snkae bites }\end{array}$ & $\begin{array}{l}\text { Afrodescendant } \\
\mathrm{s}\end{array}$ & Brazil & $\begin{array}{l}\text { Alves and Filho, } \\
2006\end{array}$ \\
\hline & $\begin{array}{l}\text { Bone and } \\
\text { fat }\end{array}$ & All population & $\begin{array}{l}\text { Sore Throat, cancer, and } \\
\text { inflammations }\end{array}$ & $\begin{array}{l}\text { Afrodescendant } \\
\mathrm{s}\end{array}$ & Brazil & $\begin{array}{l}\text { Ferreira et al., } \\
2012\end{array}$ \\
\hline $\begin{array}{l}\text { Tamandua } \\
\text { mexicana }\end{array}$ & fat & All population & Arthritis & $\begin{array}{l}\text { Afro- } \\
\text { descendants }\end{array}$ & Colombia & $\begin{array}{l}\text { Cuesta-Rios, } \\
2007\end{array}$ \\
\hline
\end{tabular}




\begin{tabular}{|c|c|c|c|c|c|c|}
\hline $\begin{array}{l}\text { Tamandua } \\
\text { tetradactyla }\end{array}$ & fat & All population & Clean blood and cure asthma & NA & Brazil & Pinto et al., 2012 \\
\hline $\begin{array}{l}\text { Tropidurus } \\
\text { hispidus }\end{array}$ & $\begin{array}{l}\text { Whole } \\
\text { animal }\end{array}$ & All population & Sore throat & NA & Brazil & $\begin{array}{l}\text { Alves et al., } \\
2010\end{array}$ \\
\hline $\begin{array}{c}\text { Tropidurus } \\
\text { semitaeniatus }\end{array}$ & $\begin{array}{l}\text { Whole } \\
\text { animal }\end{array}$ & All population & Pharyngitis, asthma, "throat cyst" & NA & Brazil & $\begin{array}{l}\text { Alves et al., } \\
2010\end{array}$ \\
\hline \multirow{4}{*}{$\begin{array}{l}\text { Tupinambis } \\
\text { merianae }\end{array}$} & Fat and tail & All population & $\begin{array}{l}\text { Score throat, coughs, asthma, } \\
\text { headache, bruises, } \\
\text { inflammations, rheumatism, flu, } \\
\text { bronchitis, arthritis, arthrosis, } \\
\text { back ache, tooache, healing, } \\
\text { deafness and earches }\end{array}$ & NA & Brazil & $\begin{array}{l}\text { Ferreira et al., } \\
2009\end{array}$ \\
\hline & $\begin{array}{l}\text { Fat and } \\
\text { skin }\end{array}$ & All population & $\begin{array}{l}\text { Earache, kidney pain, loss of } \\
\text { hearing, backache, skin } \\
\text { problems, inflammation, sore } \\
\text { throat, asthma }\end{array}$ & NA & Brazil & $\begin{array}{l}\text { Alves et al., } \\
2009\end{array}$ \\
\hline & $\begin{array}{l}\text { Fat, skin, } \\
\text { and tail }\end{array}$ & All population & $\begin{array}{l}\text { Burns, osteoporosis, healing, } \\
\text { headache }\end{array}$ & $\begin{array}{l}\text { Afrodescendant } \\
\mathrm{s}\end{array}$ & Brazil & $\begin{array}{l}\text { Ferreira et al., } \\
2012\end{array}$ \\
\hline & fat & All population & $\begin{array}{l}\text { Catarrh, asthma, throat, furuncle, } \\
\text { tonsillitis, earache }\end{array}$ & NA & Brazil & $\begin{array}{l}\text { Alves et al., } \\
2010\end{array}$ \\
\hline Varanus salvator & meat & all population & Arthritis & $\begin{array}{l}\text { Irular, } \\
\text { Kanikaran, } \\
\text { Kattunayakan, } \\
\text { Kota, Kurimbas, } \\
\text { Palliyan, } \\
\text { Paniyan, } \\
\text { Sholaga and } \\
\text { Toda }\end{array}$ & India & $\begin{array}{l}\text { Solavan et al, } \\
2004\end{array}$ \\
\hline Vulpes sp. & meat & All population & Relieves pain and fiever & $\begin{array}{l}\text { Karbi, Dimasa, } \\
\text { Bodo, } \\
\text { Assamese, } \\
\text { Bengoli, Nepali, } \\
\text { Kuki, Garo }\end{array}$ & India & $\begin{array}{l}\text { Hanse and } \\
\text { Teron, } 2012\end{array}$ \\
\hline Presbytis johnii & meat & $\begin{array}{l}\text { children } \\
\text { below } 11 \\
\text { years }\end{array}$ & Asthma & $\begin{array}{l}\text { Irular, } \\
\text { Kanikaran, } \\
\text { Kattunayakan, } \\
\text { Kota, Kurimbas, } \\
\text { Palliyan, } \\
\text { Paniyan, } \\
\text { Sholaga and } \\
\text { Toda }\end{array}$ & India & $\begin{array}{l}\text { Solavan et al, } \\
2004\end{array}$ \\
\hline Canis aureus & meat & All population & $\begin{array}{l}\text { Relieves arthritis and } \\
\text { reumathism }\end{array}$ & Mro & Bengladesh & $\begin{array}{l}\text { Chowdhury et } \\
\text { al., } 2014\end{array}$ \\
\hline Cervulus muntjac & meat & All population & $\begin{array}{l}\text { Chest pain, rheumatic pain and } \\
\text { fever }\end{array}$ & $\begin{array}{l}\text { Karbi, Dimasa, } \\
\text { Bodo, } \\
\text { Assamese, } \\
\text { Bengoli, Nepali, } \\
\text { Kuki, Garo }\end{array}$ & India & $\begin{array}{l}\text { Hanse and } \\
\text { Teron, } 2012\end{array}$ \\
\hline Sus Scrofa & meat & All population & $\begin{array}{l}\text { Relieves arthritis and } \\
\text { reumathism }\end{array}$ & Mro & Bengladesh & $\begin{array}{l}\text { Chowdhury et } \\
\text { al., } 2014\end{array}$ \\
\hline
\end{tabular}




\section{Annex 3. Zoonotic agents in bushmeat species from Africa, Latin America/Caribbean and Asia/Pacific}

\section{AFRICA}

Zoonotic parasites in bushmeat species from Africa.

\begin{tabular}{|c|c|c|c|c|c|c|}
\hline Order & Common name & Species & $\begin{array}{l}\text { Part of the } \\
\text { animal }\end{array}$ & $\begin{array}{l}\text { Pathogen or } \\
\text { Disease agent }\end{array}$ & Disease & Reference \\
\hline \multirow{10}{*}{ Reptile } & Python & Python sp. & meat & Armillifer & $\begin{array}{l}\text { Snakeborne } \\
\text { Armillifer } \\
\text { pentastomiasis }\end{array}$ & $\begin{array}{l}\text { Tappe } \text { et al., } \\
2016\end{array}$ \\
\hline & \multirow[t]{4}{*}{$\begin{array}{l}\text { Ornate monitor } \\
\text { lizards }\end{array}$} & \multirow[t]{4}{*}{ Varanus ornatus } & \multirow[t]{4}{*}{ Faeces } & $\begin{array}{l}\text { Strongyloides } \\
\text { papillosus }\end{array}$ & \multirow{4}{*}{$\begin{array}{l}\text { Enteric disease, } \\
\text { gastroenteritis, } \\
\text { others }\end{array}$} & \multirow[t]{4}{*}{$\begin{array}{l}\text { Okoye } \text { et al. } \\
2015\end{array}$} \\
\hline & & & & Trichuris trichiura & & \\
\hline & & & & $\begin{array}{l}\text { Ascaris } \\
\text { lumbricoides }\end{array}$ & & \\
\hline & & & & $\begin{array}{l}\text { Entamoeba } \\
\text { histolytica }\end{array}$ & & \\
\hline & \multirow{5}{*}{$\begin{array}{l}\text { African } \\
\text { savannah } \\
\text { monitor lizards }\end{array}$} & \multirow{5}{*}{$\begin{array}{l}\text { Varanus } \\
\text { exanthematicus }\end{array}$} & \multirow[t]{5}{*}{ Faeces } & Capillaria bursata & \multirow{5}{*}{$\begin{array}{l}\text { Enteric disease, } \\
\text { gastroenteritis, } \\
\text { others }\end{array}$} & \multirow{5}{*}{$\begin{array}{l}\text { Okoye } \text { et al. } \\
2015\end{array}$} \\
\hline & & & & Trichuris trichiura & & \\
\hline & & & & $\begin{array}{l}\text { Ascaris } \\
\text { lumbricoides }\end{array}$ & & \\
\hline & & & & $\begin{array}{l}\text { Dicrocoelium } \\
\text { hospes }\end{array}$ & & \\
\hline & & & & $\begin{array}{l}\text { Entamoeba } \\
\text { histolytica }\end{array}$ & & \\
\hline \multirow[t]{18}{*}{ Rodent } & $\begin{array}{l}\text { Brush tailed } \\
\text { porcupine }\end{array}$ & $\begin{array}{l}\text { Atherurus } \\
\text { africanus }\end{array}$ & meat & Toxoplasma gondii & Toxoplasmosis & Lussac, 2010 \\
\hline & \multirow[t]{12}{*}{ Cane rat } & \multirow{12}{*}{$\begin{array}{l}\text { Thryonomys } \\
\text { swinderianus }\end{array}$} & meat & Toxoplasma gondii & Toxoplasmosis & Lussac, 2010 \\
\hline & & & Feaces & $\begin{array}{l}\text { Strongyle } \\
\text { ova }\end{array}$ & $\begin{array}{l}\text { Gastrointestinal } \\
\text { disease }\end{array}$ & $\begin{array}{l}\text { Adejinmi and } \\
\text { Emikpe, } 2011\end{array}$ \\
\hline & & & feaces & Strongyloides & $\begin{array}{l}\text { Gastrointestinal } \\
\text { disease }\end{array}$ & $\begin{array}{l}\text { Adejinmi and } \\
\text { Emikpe, } 2011\end{array}$ \\
\hline & & & feaces & Trichuris & $\begin{array}{l}\text { Gastrointestinal } \\
\text { disease }\end{array}$ & $\begin{array}{l}\text { Adejinmi and } \\
\text { Emikpe, } 2011\end{array}$ \\
\hline & & & feaces & Cestode & $\begin{array}{l}\text { Gastrointestinal } \\
\text { disease }\end{array}$ & $\begin{array}{l}\text { Adejinmi and } \\
\text { Emikpe, } 2011\end{array}$ \\
\hline & & & feaces & Ascaris & $\begin{array}{l}\text { Gastrointestinal } \\
\text { disease }\end{array}$ & $\begin{array}{l}\text { Adejinmi and } \\
\text { Emikpe, } 2011\end{array}$ \\
\hline & & & \multirow[t]{6}{*}{ Faeces } & Trichuris trichiura & \multirow{6}{*}{$\begin{array}{l}\text { Enteric disease, } \\
\text { gastroenteritis, } \\
\text { others }\end{array}$} & \multirow{6}{*}{$\begin{array}{l}\text { Okoye } \text { et al. } \\
2015\end{array}$} \\
\hline & & & & $\begin{array}{l}\text { Ascaris } \\
\text { lumbricoides }\end{array}$ & & \\
\hline & & & & $\begin{array}{l}\text { Metastrongylus } \\
\text { elongates }\end{array}$ & & \\
\hline & & & & $\begin{array}{l}\text { Globocephalus } \\
\text { diducta }\end{array}$ & & \\
\hline & & & & $\begin{array}{l}\text { Oesophagostomum } \\
\text { columbianum }\end{array}$ & & \\
\hline & & & & $\begin{array}{l}\text { Moniliformis } \\
\text { moniliformis }\end{array}$ & & \\
\hline & \multirow[t]{5}{*}{ Wild rabbits } & \multirow[t]{5}{*}{$\begin{array}{l}\text { Oryctolagus } \\
\text { cuniculus }\end{array}$} & \multirow[t]{5}{*}{ Faeces } & $\begin{array}{l}\text { Trichostrongylus } \\
\text { retortaeformis }\end{array}$ & \multirow{5}{*}{$\begin{array}{l}\text { Enteric disease, } \\
\text { gastroenteritis, } \\
\text { others }\end{array}$} & \multirow[t]{5}{*}{$\begin{array}{l}\text { Okoye } \text { et al. } \\
2015\end{array}$} \\
\hline & & & & $\begin{array}{l}\text { Enterobius } \\
\text { vermicularis }\end{array}$ & & \\
\hline & & & & Ancylostoma sp. & & \\
\hline & & & & Taenia saginata & & \\
\hline & & & & $\begin{array}{l}\text { Dicrocoelium } \\
\text { hospes }\end{array}$ & & \\
\hline
\end{tabular}




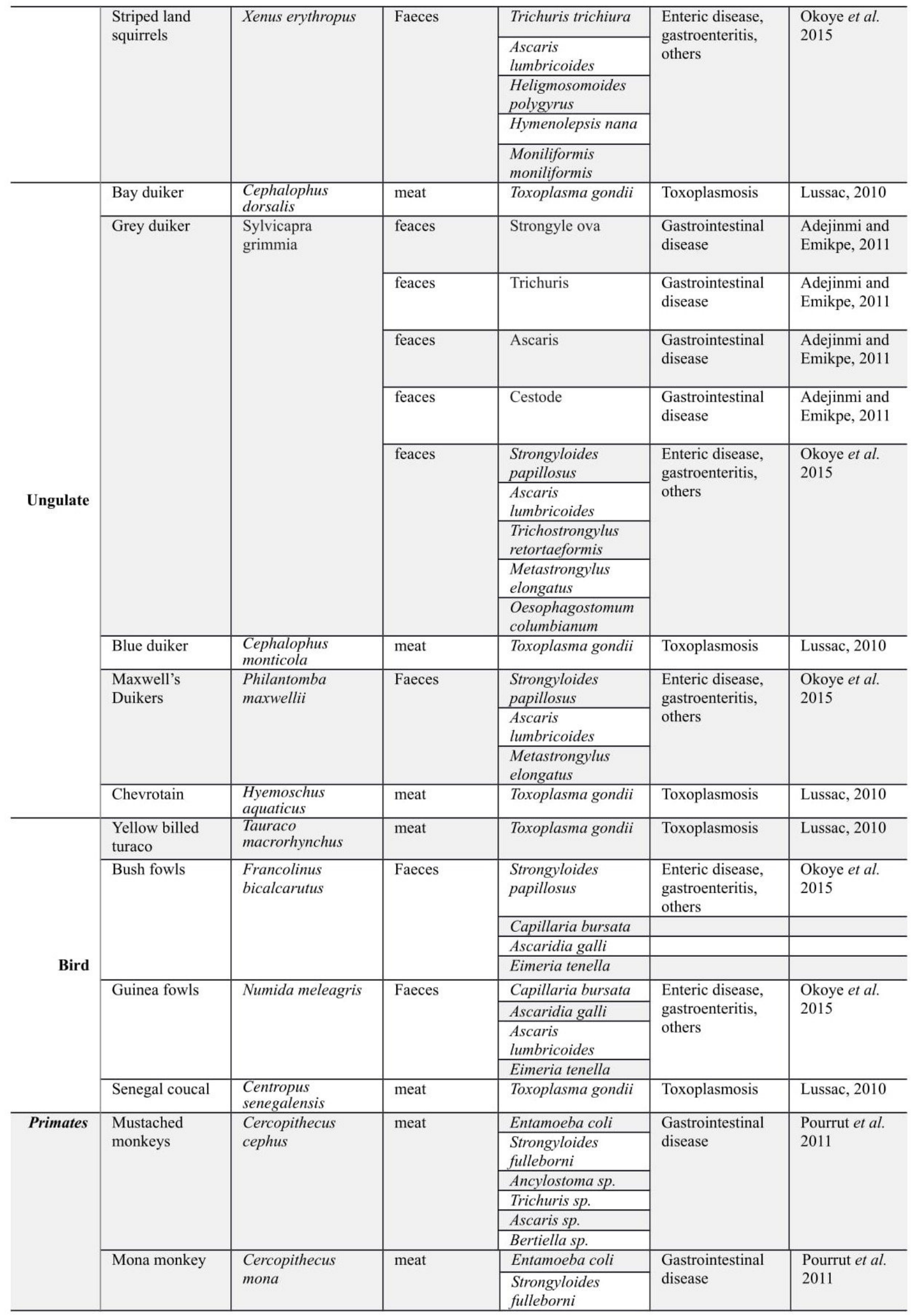




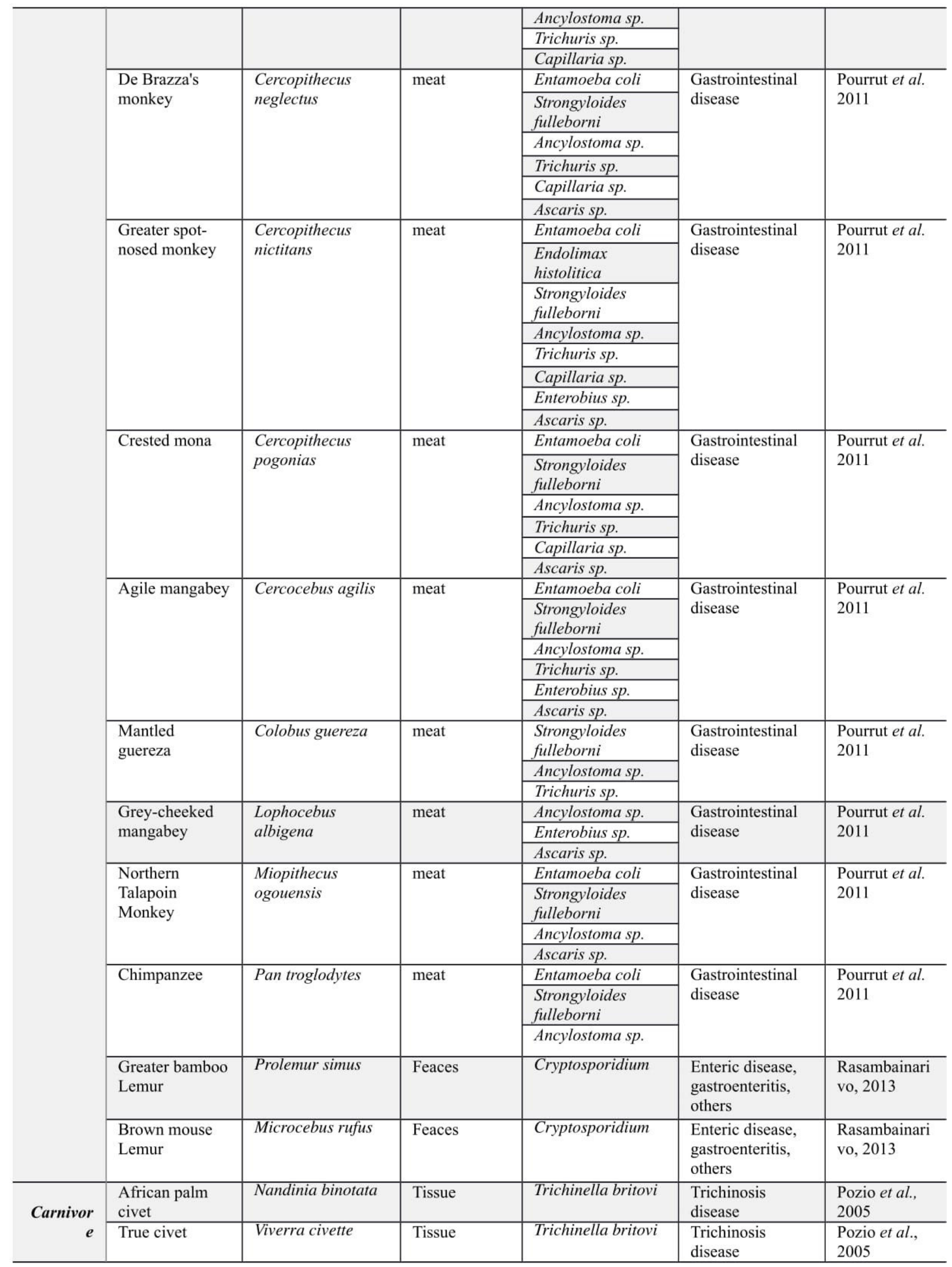


Zoonotic viruses present in bushmeat of species in Africa.

\begin{tabular}{|c|c|c|c|c|c|c|}
\hline order & $\begin{array}{r}\text { Common } \\
\text { name }\end{array}$ & Species & $\begin{array}{l}\text { Part of } \\
\text { the } \\
\text { animal }\end{array}$ & $\begin{array}{l}\text { Pathogen or } \\
\text { Disease agent }\end{array}$ & Disease & Reference \\
\hline Ungulate & Duiker & $\begin{array}{l}\text { Cephalophus } \\
\text { sp. }\end{array}$ & blood & Ebola virus & Ebola virus disease & Leroy et al., 2004a \\
\hline \multirow[t]{18}{*}{ Primate } & \multirow{3}{*}{$\begin{array}{r}\text { Agile } \\
\text { mangabey }\end{array}$} & \multirow{3}{*}{$\begin{array}{l}\text { Cercocebus } \\
\text { agilis }\end{array}$} & meat & $\begin{array}{c}\text { Simian } \\
\text { immunodeficienc } \\
y \text { virus } \\
\end{array}$ & Plethora of Simian Immunodeficiency Viruses & Peeters et al. 2002 \\
\hline & & & blood & $\begin{array}{l}\text { Simian } T \text { - } \\
\text { lymphotropic } \\
\text { virus type } 1\end{array}$ & $\begin{array}{c}\text { adult T-cell leukemia, neurological disorders } \\
\text { such as HTLV-1-associate myelopathy } \\
\text { (HAM) also known as tropical spastic } \\
\text { paraparesis (TSP), and has also been } \\
\text { associated with inflammatory diseases }\end{array}$ & Liégeois et al. 2008 \\
\hline & & & blood & $\begin{array}{l}\text { Simian } T- \\
\text { lymphotropic } \\
\text { virus type } 2 \\
\end{array}$ & Neurological disease & Liégeois et al. 2009 \\
\hline & \multirow{6}{*}{$\begin{array}{r}\text { Sooty } \\
\text { mangabey }\end{array}$} & \multirow{8}{*}{$\begin{array}{l}\text { Cercocebus } \\
\text { atys }\end{array}$} & meat & $\begin{array}{l}\text { Simian } T \text { - } \\
\text { lymphotropic } \\
\text { virus type } 1 \\
\end{array}$ & Plethora of Simian Immunodeficiency Viruses & Apetrei et al. 2005 \\
\hline & & & meat & Orthopox virus & Monkey pox disease & Apetrei et al. 2005 \\
\hline & & & blood & $\begin{array}{c}\text { Simian } T- \\
\text { lymphotropic } \\
\text { virus type } 1 \\
\end{array}$ & $\begin{array}{c}\text { T-cell leukemia or lymphoma and HTLV- } 1- \\
\text { associated myelopathy or tropical spastic } \\
\text { paraparesis }\end{array}$ & $\begin{array}{l}\text { Calvignac-Spencer } \\
\text { et al. } 2012\end{array}$ \\
\hline & & & muscle & $\begin{array}{l}\text { Simian foamy } \\
\text { virus }\end{array}$ & Plethora of Simian Immunodeficiency Viruses & Smith et al., 2012 \\
\hline & & & blood & $\begin{array}{c}\text { Simian } \\
\text { Immunodeficienc } \\
y \text { virus } \\
\end{array}$ & $\begin{array}{l}\text { Plethora of Simian Immunodeficiency } \\
\text { diseases }\end{array}$ & Ayouba et al., 2013 \\
\hline & & & blood & Ebola virus & Ebola virus disease & Leroy et al., 2004 \\
\hline & \multirow{6}{*}{$\begin{array}{r}\text { Red-capped } \\
\text { mangabey }\end{array}$} & & blood & $\begin{array}{l}\text { Simian } T- \\
\text { lymphotropic } \\
\text { virus type } 2\end{array}$ & Neurological disease & Liégeois et al. 2008 \\
\hline & & & blood & $\begin{array}{l}\text { Simian } T \text { - } \\
\text { lymphotropic } \\
\text { virus type } 3 \\
\end{array}$ & Plethora of Simian Immunodeficiency Viruses & Liégeois et al. 2012 \\
\hline & & \multirow[t]{4}{*}{ blood } & blood & $\begin{array}{c}\text { Simian } \\
\text { immunodeficienc } \\
y \text { virus }\end{array}$ & Plethora of Simian Immunodeficiency Viruses & $\begin{array}{l}\text { Aghokeng et al., } \\
2010\end{array}$ \\
\hline & & & blood & $\begin{array}{l}\text { Simian } T- \\
\text { lymphotropic } \\
\text { virus type } 1\end{array}$ & Plethora of Simian Immunodeficiency Viruses & Liégeois et al. 2013 \\
\hline & & & blood & $\begin{array}{l}\text { Simian Foamy } \\
\text { Virus } \\
\end{array}$ & $\begin{array}{l}\text { Plethora of Simian Foamy Virus and } \\
\text { Prototype foamy virus }\end{array}$ & $\begin{array}{c}\text { Mouinga-Ondémé et } \\
\text { al. } 2012 \\
\end{array}$ \\
\hline & & & blood & $\begin{array}{l}\text { Simian } T \text { - } \\
\text { lymphotropic } \\
\text { virus type } 1\end{array}$ & $\begin{array}{l}\text { Plethora of Simian Foamy Virus and } \\
\text { Prototype foamy virus }\end{array}$ & $\begin{array}{l}\text { Mouinga-Ondémé } \\
\text { and Mirdad Kazanji } \\
2013\end{array}$ \\
\hline & $\begin{array}{r}\text { Red tailed } \\
\text { monkey }\end{array}$ & $\begin{array}{l}\text { Cercopithecus } \\
\text { ascanius }\end{array}$ & blood & $\begin{array}{c}\text { Simian } T- \\
\text { lymphotropic } \\
\text { virus type } 3 \\
\end{array}$ & Plethora of Simian Immunodeficiency Viruses & $\begin{array}{l}\text { Ahuka-Mundeke et } \\
\text { al. } 2012\end{array}$ \\
\hline & \multirow[t]{2}{*}{$\begin{array}{r}\text { Mustached } \\
\text { guenon }\end{array}$} & \multirow[t]{2}{*}{$\begin{array}{c}\text { Cercopithecus } \\
\text { cephus }\end{array}$} & $\begin{array}{c}\text { Meat and } \\
\text { blood }\end{array}$ & $\begin{array}{c}\text { Simian } \\
\text { immunodeficienc } \\
y \text { virus }\end{array}$ & Plethora of Simian Immunodeficiency Viruses & $\begin{array}{l}\text { Peeters et al. } 2002 \\
\text { Courgnaud et al. } \\
2003 \\
\text { Aghokeng et al., } \\
2007\end{array}$ \\
\hline & & & meat & $\begin{array}{c}\text { Simian } T \text { - } \\
\text { lymphotropic } \\
\text { virus type } 2\end{array}$ & $\begin{array}{c}\text { adult T-cell leukemia, neurological disorders } \\
\text { such as HTLV-1-associate myelopathy } \\
\text { (HAM) also known as tropical spastic } \\
\text { paraparesis (TSP), and has also been } \\
\text { associated with inflammatory diseases }\end{array}$ & Liégeois et al., 2008 \\
\hline
\end{tabular}




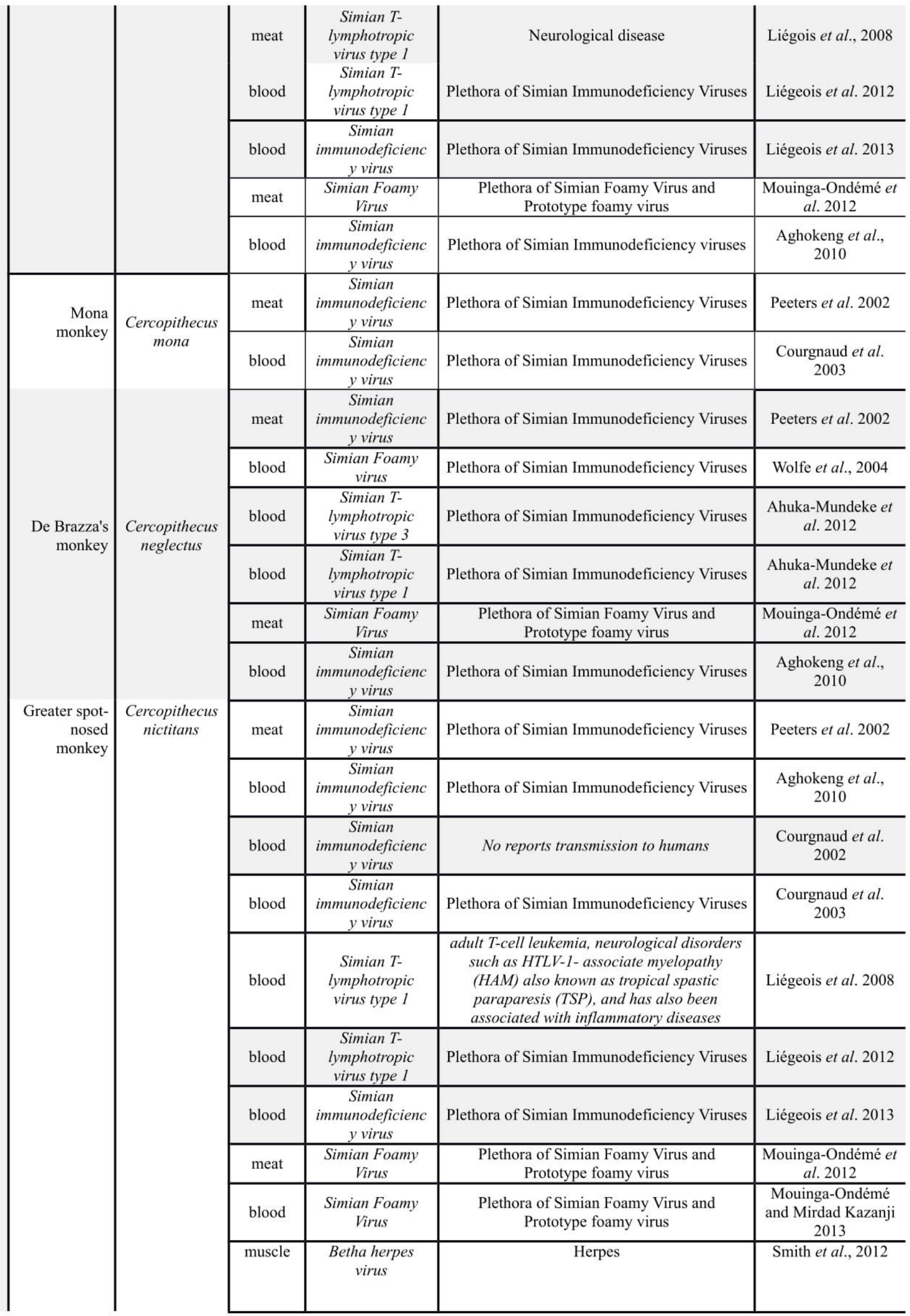




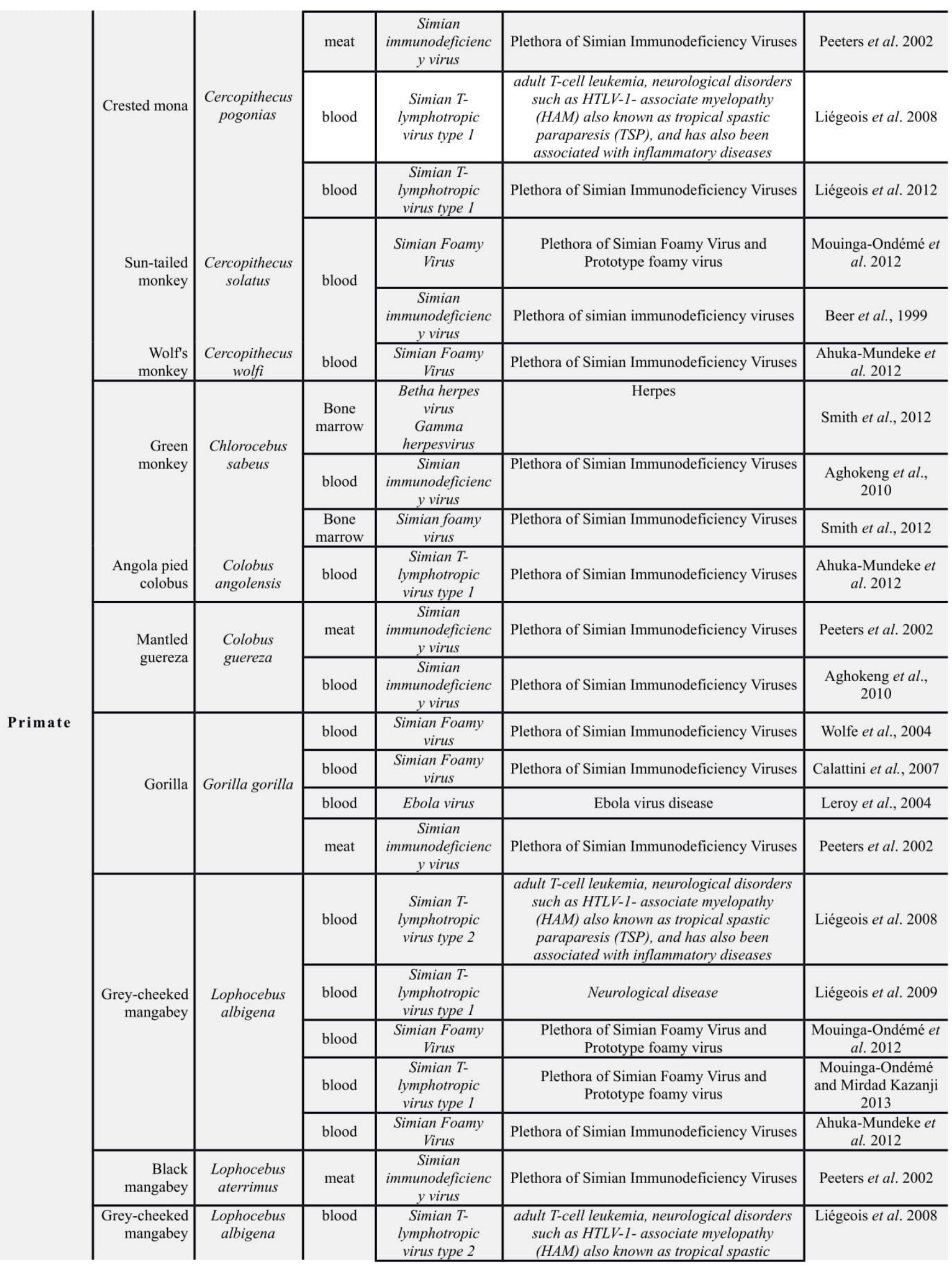




\begin{tabular}{|c|c|c|c|c|c|}
\hline & & & & $\begin{array}{l}\text { paraparesis (TSP), and has also been } \\
\text { associated with inflammatory diseases }\end{array}$ & \\
\hline & & blood & $\begin{array}{c}\text { Simian } T- \\
\text { lymphotropic } \\
\text { virus type 1 }\end{array}$ & Neurological disease & Liégeois et al. 2009 \\
\hline & & blood & $\begin{array}{l}\text { Simian Foamy } \\
\text { Virus } \\
\end{array}$ & $\begin{array}{c}\text { Plethora of Simian Foamy Virus and } \\
\text { Prototype foamy virus }\end{array}$ & $\begin{array}{c}\text { Mouinga-Ondémé et } \\
\text { al. } 2012 \\
\end{array}$ \\
\hline & & blood & $\begin{array}{c}\text { Simian } T- \\
\text { lymphotropic } \\
\text { virus type } 1 \\
\end{array}$ & $\begin{array}{c}\text { Plethora of Simian Foamy Virus and } \\
\text { Prototype foamy virus }\end{array}$ & 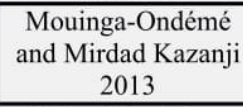 \\
\hline & & blood & $\begin{array}{c}\text { Simian Foamy } \\
\text { Virus } \\
\end{array}$ & Plethora of Simian Immunodeficiency Viruses & $\begin{array}{c}\text { Ahuka-Mundeke } e t \\
\text { al. } 2012 \\
\end{array}$ \\
\hline $\begin{array}{r}\text { Black } \\
\text { mangabey }\end{array}$ & $\begin{array}{l}\text { Lophocebus } \\
\text { aterrimus }\end{array}$ & blood & Ebola virus & Ebola virus disease & Leroy et al., 2004 \\
\hline Drill & $\begin{array}{l}\text { Mandrillus } \\
\text { leucophaeus }\end{array}$ & blood & $\begin{array}{l}\text { Simian Foamy } \\
\text { virus }\end{array}$ & Plethora of Simian Immunodeficiency Viruses & Wolfe et al., 2004 \\
\hline \multirow[t]{17}{*}{ Mandrill } & \multirow[t]{17}{*}{$\begin{array}{l}\text { Mandrillus } \\
\text { sphinx }\end{array}$} & blood & $\begin{array}{c}\text { Simian Foamy } \\
\text { virus }\end{array}$ & Plethora of Simian Immunodeficiency Viruses & Wolfe et al., 2004 \\
\hline & & blood & Ebola virus & Ebola virus disease & Leroy et al., 2004 \\
\hline & & blood & $\begin{array}{c}\text { Simian } \\
\text { immunodeficienc } \\
\text { y virus }\end{array}$ & Plethora of Simian Immunodeficiency Viruses & Ndembi et al. 2007 \\
\hline & & blood & $\begin{array}{l}\text { Simian } T \text { - } \\
\text { lymphotropic } \\
\text { virus type } 1\end{array}$ & \begin{tabular}{|c|} 
adult T-cell leukemia, neurological disorders \\
such as HTLV-1-associate myelopathy \\
(HAM) also known as tropical spastic \\
paraparesis (TSP), and has also been \\
associated with inflammatory diseases \\
\end{tabular} & Liégeois et al. 2008 \\
\hline & & blood & $\begin{array}{c}\text { Simian } T- \\
\text { lymphotropic } \\
\text { virus type } 3 \\
\end{array}$ & Plethora of Simian Immunodeficiency Viruses & Liégeois et al. 2012 \\
\hline & & blood & $\begin{array}{c}\text { Simian } T- \\
\text { lymphotropic } \\
\text { virus type } 1 \\
\end{array}$ & Plethora of Simian Immunodeficiency Viruses & Liégeois et al. 2013 \\
\hline & & blood & $\begin{array}{c}\text { Simian } \\
\text { immunodeficienc } \\
\text { y virus }\end{array}$ & Plethora of Simian Immunodeficiency Viruses & Liégeois et al. 2014 \\
\hline & & meat & $\begin{array}{l}\text { Simian Foamy } \\
\text { Virus } \\
\end{array}$ & $\begin{array}{c}\text { Plethora of Simian Foamy Virus and } \\
\text { Prototype foamy virus }\end{array}$ & $\begin{array}{c}\text { Mouinga-Ondémé et } \\
\text { al. } 2012 \\
\end{array}$ \\
\hline & & blood & $\begin{array}{c}\text { Simian } \\
\text { immunodeficienc } \\
\text { y virus } \\
\end{array}$ & Plethora of Simian Immunodeficiency Viruses & 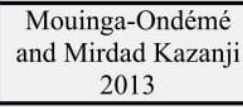 \\
\hline & & blood & $\begin{array}{c}\text { Simian } \\
\text { immunodeficienc } \\
\text { y virus } \\
\end{array}$ & Plethora of Simian Immunodeficiency Viruses & $\begin{array}{l}\text { Aghokeng et al., } \\
2010\end{array}$ \\
\hline & & meat & $\begin{array}{l}\text { Simian } \\
\text { immunodeficienc } \\
y \text { virus }\end{array}$ & Plethora of Simian Immunodeficiency Viruses & $\begin{array}{c}\text { Tsujimoto } \text { et al., } \\
1989 \\
\text { Peeters et al. } 2002\end{array}$ \\
\hline & & meat & $\begin{array}{l}\text { Simian } \\
\text { immunodeficienc } \\
\text { y virus }\end{array}$ & Plethora of Simian Immunodeficiency Viruses & $\begin{array}{c}\text { Tsujimoto } \text { et al., } \\
1989 \\
\text { Peeters et al. } 2002\end{array}$ \\
\hline & & blood & Ebola virus & Ebola virus disease & Leroy et al., 2004 \\
\hline & & blood & $\begin{array}{c}\text { Simian } \\
\text { immunodeficienc } \\
\text { y virus } \\
\end{array}$ & Plethora of Simian Immunodeficiency Viruses & Ndembi et al. 2007 \\
\hline & & blood & $\begin{array}{l}\text { Simian } T \text { - } \\
\text { lymphotropic } \\
\text { virus type } 1\end{array}$ & \begin{tabular}{|c|} 
adult $T$-cell leukemia, neurological disorders \\
such as HTLV-1-associate myelopathy \\
(HAM) also known as tropical spastic \\
paraparesis (TSP), and has also been \\
associated with inflammatory diseases
\end{tabular} & Liégeois et al. 2008 \\
\hline & & blood & $\begin{array}{c}\text { Simian } T- \\
\text { lymphotropic } \\
\text { virus type } 3 \\
\end{array}$ & Plethora of Simian Immunodeficiency Viruses & Liégeois et al. 2012 \\
\hline & & blood & $\begin{array}{c}\text { Simian } T- \\
\text { lymphotropic }\end{array}$ & Plethora of Simian Immunodeficiency Viruses & Liégeois et al. 2013 \\
\hline
\end{tabular}




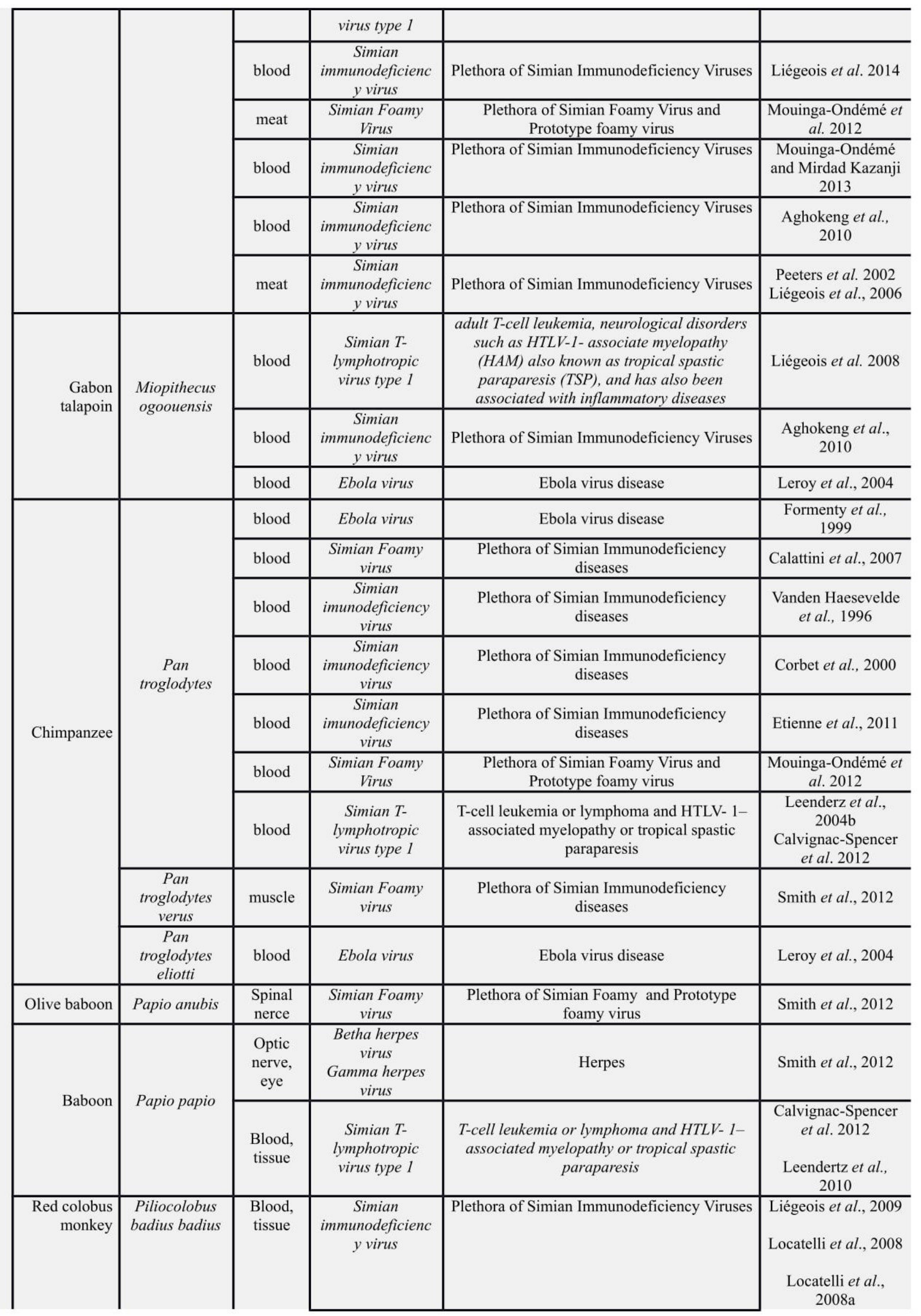




\begin{tabular}{|c|c|c|c|c|c|c|}
\hline & & & & & & $\begin{array}{c}\text { Leendertz et al., } \\
2010\end{array}$ \\
\hline & & & $\begin{array}{l}\text { Blood, } \\
\text { tissue }\end{array}$ & $\begin{array}{l}\text { Simian Foamy } \\
\text { Virus }\end{array}$ & Plethora of Simian Immunodeficiency Viruses & $\begin{array}{l}\text { Leendertz et al., } \\
\quad 2010\end{array}$ \\
\hline & & & blood & $\begin{array}{l}\text { Simian Foamy } \\
\text { Virus }\end{array}$ & Plethora of Simian Immunodeficiency Viruses & $\begin{array}{c}\text { Ahuka-Mundeke } e t \\
\text { al. } 2012\end{array}$ \\
\hline & $\begin{array}{r}\text { Thsuapa red } \\
\text { colobus }\end{array}$ & $\begin{array}{c}\text { Piliocolobus } \\
\text { tholloni }\end{array}$ & $\begin{array}{c}\text { Blood } \\
\text { and } \\
\text { tissue }\end{array}$ & $\begin{array}{c}\text { Simian } \\
\text { immunodeficienc } \\
y \text { viruses }\end{array}$ & Plethora of simian immunodeficiency viruses & Liégois et al., 2009 \\
\hline & Olive colobus & $\begin{array}{c}\text { Procolobus } \\
\text { verus }\end{array}$ & $\begin{array}{c}\text { Animal } \\
\text { tissue }\end{array}$ & Orthopoxvirus & Human monkey pox & $\begin{array}{c}\text { Reynolds et al., } \\
2010 \\
\end{array}$ \\
\hline Rodent & Pouched rat & Cricetomys sp. & blood & Nipah virus & acute encephalitis and respiratory illness & \multirow{2}{*}{$\begin{array}{l}\text { Pernet et al., } 2012 \\
\text { Hayman et al., } 2010\end{array}$} \\
\hline \multirow{11}{*}{ Chiroptera } & \multirow{2}{*}{$\begin{array}{r}\text { Straw colour } \\
\text { fruit bat }\end{array}$} & \multirow{3}{*}{$\begin{array}{l}\text { Eidolon } \\
\text { helvum } \\
\text { Epomops } \\
\text { franqueti }\end{array}$} & blood & Ebola virus & Ebola virus disease & \\
\hline & & & blood & Ebola virus & Ebola virus disease & Pourrut et al., 2009 \\
\hline & $\begin{array}{l}\text { Franquet's } \\
\text { Epauletted } \\
\end{array}$ & & $\begin{array}{c}\text { Animal } \\
\text { tissue }\end{array}$ & Orthopoxvirus & Human monkey pox & $\begin{array}{c}\text { Reynolds et al., } \\
2010\end{array}$ \\
\hline & Dormouse & Graphiurus sp. & $\begin{array}{c}\text { Animal } \\
\text { tissue }\end{array}$ & Orthopoxvirus & Human monkey pox & $\begin{array}{c}\text { Reynolds et al., } \\
2010\end{array}$ \\
\hline & Sun Squirrel & $\begin{array}{c}\text { Heliosciurus } \\
\text { sp. }\end{array}$ & blood & Ebola virus & Ebola virus disease & Pourrut et al., 2009 \\
\hline & $\begin{array}{c}\text { Hammer } \\
\text { headed bat }\end{array}$ & $\begin{array}{l}\text { Hypsignathus } \\
\text { monstrosus }\end{array}$ & blood & Ebola virus & Ebola virus disease & Pourrut et al., 2009 \\
\hline & \begin{tabular}{|c|}
$\begin{array}{c}\text { Peter's dwarf } \\
\text { epauletted } \\
\text { fruit bat }\end{array}$ \\
\end{tabular} & $\begin{array}{l}\text { Micropteropus } \\
\text { pusillus }\end{array}$ & blood & Ebola virus & Ebola virus disease & Pourrut et al., 2009 \\
\hline & $\begin{array}{c}\text { Angolan free } \\
\text { tailed bat }\end{array}$ & $\begin{array}{c}\text { Mops } \\
\text { condylurus }\end{array}$ & blood & Ebola virus & Ebola virus disease & Pourrut et al., 2009 \\
\hline & \begin{tabular}{|c|}
$\begin{array}{c}\text { Little collared } \\
\text { fruit bat }\end{array}$ \\
\end{tabular} & $\begin{array}{c}\text { Myonycteris } \\
\text { torquata }\end{array}$ & blood & Marburg virus & Marburg virus disease & $\begin{array}{c}\text { Swanepoel et al., } \\
2007\end{array}$ \\
\hline & $\begin{array}{r}\text { Eloquent } \\
\text { horseshoe bat } \\
\end{array}$ & $\begin{array}{l}\text { Rhinolophus } \\
\text { eloquens }\end{array}$ & blood & Marburg virus & Marburg virus disease & $\begin{array}{l}\text { Swanepoel et al., } \\
2007\end{array}$ \\
\hline & $\begin{array}{r}\text { Egyptian fruit } \\
\text { bat }\end{array}$ & $\begin{array}{l}\text { Rousettus } \\
\text { aegyptiacus }\end{array}$ & blood & Ebola virus & Ebola virus disease & Pourrut et al., 2009 \\
\hline
\end{tabular}


Zoonotic bacteria and other diseases present in bushmeat of species in Africa.

\begin{tabular}{|c|c|c|c|c|c|c|c|}
\hline Order & $\begin{array}{r}\text { Common } \\
\text { name }\end{array}$ & Species & $\begin{array}{l}\text { Part of the } \\
\text { animal }\end{array}$ & $\begin{array}{l}\text { Pathogen or } \\
\text { Disease agent }\end{array}$ & $\begin{array}{l}\text { Pathoge } \\
\text { n Type }\end{array}$ & Disease & Reference \\
\hline \multirow{2}{*}{ Rodent } & $\begin{array}{r}\text { African- } \\
\text { crested } \\
\text { porcupine }\end{array}$ & $\begin{array}{l}\text { Atherurus } \\
\text { africanus }\end{array}$ & bushmeat & Sallmonella spp. & Bacteria & $\begin{array}{l}\text { Enteric disease, } \\
\text { gastroenteritis }\end{array}$ & $\begin{array}{l}\text { Bachand et } \\
\text { al. } 2012\end{array}$ \\
\hline & $\begin{array}{r}\text { Gambian } \\
\text { Pouched } \\
\text { Rat }\end{array}$ & $\begin{array}{l}\text { Crycetomys } \\
\text { gambianus }\end{array}$ & $\begin{array}{l}\text { Tongue, } \\
\text { bicepts, } \\
\text { muscles }\end{array}$ & Trichinella & Bacteria & Trichinellosis & $\begin{array}{l}\text { Mbaya et al., } \\
2010\end{array}$ \\
\hline \multirow{7}{*}{ Ungulate } & \multirow{3}{*}{$\begin{array}{l}\text { African } \\
\text { buffalo }\end{array}$} & \multirow{3}{*}{$\begin{array}{l}\text { Syncerus } \\
\text { caffer }\end{array}$} & \multirow{3}{*}{$\begin{array}{l}\text { smoked } \\
\text { game meat }\end{array}$} & Escherichia coli & \multirow[t]{3}{*}{ Bacteria } & \multirow{3}{*}{$\begin{array}{l}\text { Enteric disease, } \\
\text { gastroenteritis }\end{array}$} & \multirow{3}{*}{$\begin{array}{l}\text { a Mpalang et } \\
\text { al. } 2013\end{array}$} \\
\hline & & & & Salmonella spp. & & & \\
\hline & & & & $\begin{array}{l}\text { Campylobacter } \\
\text { spp. }\end{array}$ & & & \\
\hline & \multirow[t]{3}{*}{ Warthog } & \multirow{3}{*}{$\begin{array}{l}\text { Phacochoeru } \\
\text { s aethiopicus }\end{array}$} & \multirow{3}{*}{$\begin{array}{l}\text { smoked } \\
\text { game meat }\end{array}$} & Escherichia coli & \multirow[t]{3}{*}{ Bacteria } & \multirow{3}{*}{$\begin{array}{l}\text { Enteric disease, } \\
\text { gastroenteritis }\end{array}$} & \multirow{3}{*}{$\begin{array}{l}\text { a Mpalang et } \\
\text { al. } 2013\end{array}$} \\
\hline & & & & Salmonella spp. & & & \\
\hline & & & & $\begin{array}{l}\text { Campylobacter } \\
\text { spp. }\end{array}$ & & & \\
\hline & $\begin{array}{r}\text { common } \\
\text { duiker }\end{array}$ & $\begin{array}{l}\text { Sylvicapra } \\
\text { grimmia }\end{array}$ & $\begin{array}{l}\text { smoked } \\
\text { game meat }\end{array}$ & Escherichia coli & Bacteria & $\begin{array}{l}\text { Enteric disease, } \\
\text { gastroenteritis }\end{array}$ & $\begin{array}{l}\text { a Mpalang et } \\
\text { al. } 2013\end{array}$ \\
\hline \multirow{4}{*}{ Primate } & $\begin{array}{r}\text { Chimpanze } \\
\mathrm{e}\end{array}$ & $\begin{array}{l}\text { Pan } \\
\text { troglodytes } \\
\text { verus }\end{array}$ & $\begin{array}{l}\text { Lung tissue } \\
\text { Tissue and } \\
\text { bones }\end{array}$ & Bacillus anthracis & Bacteria & $\begin{array}{l}\text { Respiratory and } \\
\text { gastro-intestical } \\
\text { diseases }\end{array}$ & $\begin{array}{l}\text { Leendertz et } \\
\text { al., } 2004 \\
\text { Leendertz et } \\
\text { al., } 2006\end{array}$ \\
\hline & Gorilla & $\begin{array}{l}\text { Gorilla } \\
\text { gorilla }\end{array}$ & $\begin{array}{l}\text { Tissue and } \\
\text { boes }\end{array}$ & Bacillus anthracis & Bacteria & $\begin{array}{l}\text { Respiratory and } \\
\text { gastro-intestical } \\
\text { diseases }\end{array}$ & $\begin{array}{l}\text { Leendertz et } \\
\text { al., } 2006\end{array}$ \\
\hline & $\begin{array}{r}\text { Broad nose } \\
\text { gentle } \\
\text { Lemur }\end{array}$ & $\begin{array}{l}\text { Prolemur } \\
\text { simus }\end{array}$ & NA & $\begin{array}{l}\text { Cryptosporidium } \\
\text { sp. } \\
\text { Giardia sp. }\end{array}$ & protozoa & Cryptosporidiosis & $\begin{array}{l}\text { Rasambainar } \\
\text { ivo } 2013\end{array}$ \\
\hline & $\begin{array}{l}\text { Brown } \\
\text { mouse } \\
\text { Lemur }\end{array}$ & $\begin{array}{l}\text { Microcebus } \\
\text { rufus }\end{array}$ & NA & $\begin{array}{l}\text { Cryptosporidium } \\
\text { sp. } \\
\text { Giardia sp. }\end{array}$ & protozoa & Cryptosporidiosis & $\begin{array}{l}\text { Rasambainar } \\
\text { ivo } 2013\end{array}$ \\
\hline Carnivore & $\begin{array}{r}\text { Banded } \\
\text { mangoose }\end{array}$ & $\begin{array}{l}\text { Mungos } \\
\text { mungo }\end{array}$ & kidney & $\begin{array}{l}\text { Leptospira } \\
\text { interrogans }\end{array}$ & bacteria & Leptospirosis & $\begin{array}{l}\text { Jobbins et al. } \\
2014\end{array}$ \\
\hline
\end{tabular}




\section{Latin America and Caribbean}

Zoonotic parasites in bushmeat of species in Latin America and Caribbean

\begin{tabular}{|c|c|c|c|c|c|c|}
\hline Order & $\begin{array}{r}\text { Common } \\
\text { name }\end{array}$ & Species & $\begin{array}{l}\text { Part of the } \\
\text { animal }\end{array}$ & $\begin{array}{l}\text { Pathogen or Disease } \\
\text { agent }\end{array}$ & Disease & Reference \\
\hline \multirow{4}{*}{ Primate } & $\begin{array}{r}\text { Wild-caught } \\
\text { Caribbean } \\
\text { green monkey }\end{array}$ & $\begin{array}{l}\text { Chlorocebus } \\
\text { sabaeus }\end{array}$ & Blood & Toxoplasma gondii & Toxoplasmosis & $\begin{array}{l}\text { Hamilton et } \\
\text { al. } 2014\end{array}$ \\
\hline & $\begin{array}{r}\text { Howler } \\
\text { monkey }\end{array}$ & $\begin{array}{l}\text { Alouatta } \\
\text { seniculus }\end{array}$ & Serum & Toxoplasma gondii & Toxoplasmosis & $\begin{array}{l}\text { Carme et al, } \\
2002\end{array}$ \\
\hline & $\begin{array}{l}\text { Howler } \\
\text { monkey }\end{array}$ & $\begin{array}{l}\text { Alouatta } \\
\text { seniculus }\end{array}$ & Serum & Toxoplasma gondii & Toxoplasmosis & $\begin{array}{l}\text { Thois et al., } \\
2003\end{array}$ \\
\hline & $\begin{array}{r}\text { Spider } \\
\text { monkey }\end{array}$ & $\begin{array}{l}\text { Ateles } \\
\text { paniscus }\end{array}$ & liver & Capillaria hepatica & $\begin{array}{l}\text { hepatic fibrosis of } \\
\text { varying degree } \\
\text { and } \\
\text { granulomatous } \\
\text { inflammation }\end{array}$ & $\begin{array}{l}\text { Pereira- } \\
\text { Soares et al. } \\
2011\end{array}$ \\
\hline \multirow{2}{*}{ Rodent } & Porcupine & Coendou spp & Serum & Trypanosoma cruzi & Chagas disease & $\begin{array}{l}\text { Coura et al., } \\
2002\end{array}$ \\
\hline & Kinkajou & Potos flavus & Serum & Toxoplasma gondii & Toxoplasmosis & $\begin{array}{l}\text { Thois et al., } \\
2003\end{array}$ \\
\hline Carnivore & Tayra & Nasua nasua & Serum & Toxoplasma gondii & Toxoplasmosis & $\begin{array}{l}\text { Thois et al., } \\
2003\end{array}$ \\
\hline \multirow{2}{*}{ Pilosa } & \multirow[t]{2}{*}{ Anteater } & \multirow[t]{2}{*}{ T.tetradactyla } & Serum & Toxoplasma gondii & Toxoplasmosis & $\begin{array}{l}\text { Carme et al, } \\
2002\end{array}$ \\
\hline & & & Serum & Toxoplasma gondii & Toxoplasmosis & $\begin{array}{l}\text { Thois et al., } \\
2003\end{array}$ \\
\hline \multirow{4}{*}{ Didelphimorphia } & \multirow[t]{2}{*}{ Opossum } & \multirow[t]{2}{*}{$\begin{array}{l}\text { Didelphis } \\
\text { marsupialis }\end{array}$} & Serum & Toxoplasma gondii & Toxoplasmosis & $\begin{array}{l}\text { Carme } \text { et al, } \\
2002\end{array}$ \\
\hline & & & Serum & Toxoplasma gondii & Toxoplasmosis & $\begin{array}{l}\text { Thois et al., } \\
2003\end{array}$ \\
\hline & $\begin{array}{r}\text { Grey for eyed } \\
\text { opossum }\end{array}$ & $\begin{array}{l}\text { Philander } \\
\text { opossum }\end{array}$ & Serum & Trypanosoma cruzi & Chagas disease & $\begin{array}{l}\text { Coura et al., } \\
2002\end{array}$ \\
\hline & $\begin{array}{l}\text { White eared } \\
\text { opossum }\end{array}$ & $\begin{array}{l}\text { Didelphis } \\
\text { albiventris }\end{array}$ & Serum & Toxoplasma gondii & Toxoplasmosis & $\begin{array}{l}\text { Thois et al., } \\
2003\end{array}$ \\
\hline \multirow[t]{10}{*}{ Ungulate } & \multirow[t]{2}{*}{$\begin{array}{r}\text { Collared } \\
\text { peccary }\end{array}$} & \multirow[t]{2}{*}{$\begin{array}{l}\text { Tayassu } \\
\text { tayacu }\end{array}$} & Serum & Toxoplasma gondii & Toxoplasmosis & $\begin{array}{l}\text { Carme } \text { et al, } \\
2002\end{array}$ \\
\hline & & & Serum & Toxoplasma gondii & Toxoplasmosis & $\begin{array}{l}\text { Thois et al., } \\
2003\end{array}$ \\
\hline & $\begin{array}{r}\text { White leaped } \\
\text { peccary }\end{array}$ & $\begin{array}{l}\text { Tayassu } \\
\text { pecari }\end{array}$ & liver & Capillaria hepatica & $\begin{array}{l}\text { hepatic fibrosis of } \\
\text { varying degree } \\
\text { and } \\
\text { granulomatous } \\
\text { inflammation }\end{array}$ & $\begin{array}{l}\text { Pereira- } \\
\text { Soares } \text { et al. } \\
2011\end{array}$ \\
\hline & \multirow[t]{2}{*}{ Deer } & \multirow[t]{2}{*}{$\begin{array}{l}\text { Massama } \\
\text { spp. }\end{array}$} & serum & Toxoplasma gondii & Toxoplasmosis & $\begin{array}{l}\text { Carme et al, } \\
2002\end{array}$ \\
\hline & & & serum & Toxoplasma gondii & Toxoplasmosis & $\begin{array}{l}\text { Thois et al., } \\
2003\end{array}$ \\
\hline & \multirow[t]{2}{*}{ Agouti } & \multirow[t]{2}{*}{$\begin{array}{l}\text { Dasyprocta } \\
\text { puntata }\end{array}$} & serum & Toxoplasma gondii & Toxoplasmosis & $\begin{array}{l}\text { Carme } \text { et al, } \\
2002\end{array}$ \\
\hline & & & serum & Toxoplasma gondii & Toxoplasmosis & $\begin{array}{l}\text { Thois et al., } \\
2003\end{array}$ \\
\hline & Acouchy & $\begin{array}{l}\text { Myoprocta } \\
\text { acouchy }\end{array}$ & serum & Toxoplasma gondii & Toxoplasmosis & $\begin{array}{l}\text { Thois et al., } \\
2003\end{array}$ \\
\hline & \multirow[t]{2}{*}{ Paca } & \multirow[t]{2}{*}{$\begin{array}{l}\text { Cuniculus } \\
\text { paca }\end{array}$} & $\begin{array}{l}\text { Thoracic, } \\
\text { abdominal organs, } \\
\text { liver }\end{array}$ & Echinococcus vogeli & $\begin{array}{l}\text { Polycystic } \\
\text { echinococcosis }\end{array}$ & $\begin{array}{l}\text { Mayor et al. } \\
2015 \\
\text { Almeida et } \\
\text { al., } 2013\end{array}$ \\
\hline & & & liver & Calodium hepaticum & focal necrosis & $\begin{array}{l}\text { Almeida et } \\
\text { al., } 2013\end{array}$ \\
\hline
\end{tabular}




\begin{tabular}{|c|c|c|c|c|c|c|}
\hline & & & serum & Toxoplasma gondii & Toxoplasmosis & $\begin{array}{l}\text { Carme et al, } \\
2002\end{array}$ \\
\hline & & & serum & Toxoplasma gondii & Toxoplasmosis & $\begin{array}{l}\text { Thois et al., } \\
2003\end{array}$ \\
\hline & Capybara & $\begin{array}{l}\text { Hydrochaeris } \\
\text { hydrochaeris }\end{array}$ & blood & Toxoplasma gondii & Toxoplasmosis & $\begin{array}{l}\text { Truppel et al. } \\
2010\end{array}$ \\
\hline \multirow{5}{*}{ Cingulata } & \multirow[t]{4}{*}{$\begin{array}{r}\text { Nine-banded } \\
\text { armadillo }\end{array}$} & \multirow[t]{4}{*}{$\begin{array}{l}\text { Dasypus } \\
\text { novemcinctus }\end{array}$} & serum & Toxoplasma gondii & Toxoplasmosis & $\begin{array}{l}\text { da Silva et al. } \\
2006\end{array}$ \\
\hline & & & serum & Toxoplasma gondii & Toxoplasmosis & $\begin{array}{l}\text { Carme et al, } \\
2002\end{array}$ \\
\hline & & & serum & Toxoplasma gondii & Toxoplasmosis & $\begin{array}{l}\text { Thois et al., } \\
2003\end{array}$ \\
\hline & & & serum & Trypanosoma cruzi & Chagas disease & $\begin{array}{l}\text { Coura et al. } \\
2002\end{array}$ \\
\hline & $\begin{array}{r}\text { Six-banded } \\
\text { armadillo }\end{array}$ & $\begin{array}{l}\text { Euphractus } \\
\text { sexcinctus }\end{array}$ & serum & Toxoplasma gondii & Toxoplasmosis & $\begin{array}{l}\text { da Silva et al. } \\
2006\end{array}$ \\
\hline
\end{tabular}

\section{Zoonotic bacteria in bushmeat of species in Latin America and Caribbean}

\begin{tabular}{|c|c|c|c|c|c|c|}
\hline Order & $\begin{array}{r}\text { Common } \\
\text { name } \\
\end{array}$ & Species & $\begin{array}{l}\text { Part of the } \\
\text { animal }\end{array}$ & $\begin{array}{l}\text { Pathogen or Disease } \\
\text { agent }\end{array}$ & Disease & Reference \\
\hline \multirow{10}{*}{ Ungulates } & \multirow[t]{3}{*}{ Capibara } & \multirow[t]{3}{*}{$\begin{array}{l}\text { Hydrochaeri } \\
s \\
\text { hydrochaeris }\end{array}$} & \multirow[t]{3}{*}{ raw meat } & Staphylococcus aureus & $\begin{array}{l}\text { Food poisoning con } \\
\text { nausea, vomiting, } \\
\text { abdominal pain and } \\
\text { prostration }\end{array}$ & \multirow[t]{3}{*}{ Sarkis 2002} \\
\hline & & & & Clostridium & Gastroenteritis & \\
\hline & & & & Fecal coliforms & $\begin{array}{l}\text { Enteric disease, } \\
\text { gastroenteritis }\end{array}$ & \\
\hline & \multirow[t]{4}{*}{$\begin{array}{r}\text { Collared } \\
\text { peccary }\end{array}$} & \multirow[t]{4}{*}{$\begin{array}{l}\text { Tayassu } \\
\text { tajacu }\end{array}$} & raw meat & Staphylococcus aureus & $\begin{array}{l}\text { Food poisoning con } \\
\text { nausea, vomiting, } \\
\text { abdominal pain and } \\
\text { prostration }\end{array}$ & Sarkis 2002 \\
\hline & & & \multirow[t]{2}{*}{ raw meat } & Clostridium & Gastroenteritis & \multirow[t]{2}{*}{ Sarkis 2002} \\
\hline & & & & Fecal coliforms & $\begin{array}{l}\text { Enteric disease, } \\
\text { gastroenteritis }\end{array}$ & \\
\hline & & & $\begin{array}{l}\text { spleen, liver, } \\
\text { mesenteric and } \\
\text { retropharyngeal } \\
\text { lymph nodes, } \\
\text { sera, eyes and } \\
\text { blood }\end{array}$ & Brucella suis & Several infections & $\begin{array}{l}\text { Lord et al. } \\
1991\end{array}$ \\
\hline & \multirow[t]{3}{*}{ Javali } & \multirow[t]{3}{*}{$\begin{array}{l}\text { Sus scrofa } \\
\text { scrofa }\end{array}$} & \multirow[t]{3}{*}{ raw meat } & Staphylococcus aureus & $\begin{array}{l}\text { Food poisoning con } \\
\text { nausea, vomiting, } \\
\text { abdominal pain and } \\
\text { prostration }\end{array}$ & \multirow[t]{3}{*}{ Sarkis 2002} \\
\hline & & & & Clostridium & Gastroenteritis & \\
\hline & & & & Fecal coliforms & $\begin{array}{l}\text { Enteric disease, } \\
\text { gastroenteritis }\end{array}$ & \\
\hline \multirow{2}{*}{ Cingulata } & $\begin{array}{r}\text { Nine-banded } \\
\text { armadillo }\end{array}$ & $\begin{array}{l}\text { Dasypus } \\
\text { novemcinctu } \\
s\end{array}$ & $\begin{array}{l}\text { ear, nose, liver } \\
\text { and spleen }\end{array}$ & Mycobacterium leprae & Leprosy & $\begin{array}{l}\text { Cunga-Frota } \\
\text { et al. } 2012\end{array}$ \\
\hline & $\begin{array}{r}\text { Six-banded } \\
\text { armadillo }\end{array}$ & $\begin{array}{l}\text { Euphractus } \\
\text { sexcinctus }\end{array}$ & $\begin{array}{l}\text { ear, nose, liver } \\
\text { and spleen }\end{array}$ & Mycobacterium leprae & Leprosy & $\begin{array}{l}\text { Cunga-Frota } \\
\text { et al. } 2012\end{array}$ \\
\hline
\end{tabular}


Asia and Pacific region

Zoonotic bacteria and parasites in bushmeat of species in Asia and Pacific

\begin{tabular}{c|r|l|l|l|l|l}
\hline Order & $\begin{array}{r}\text { Common } \\
\text { name }\end{array}$ & Species & $\begin{array}{l}\text { Part of the } \\
\text { animal }\end{array}$ & Pathogen or Disease agent & Disease & Reference \\
\hline \multirow{5}{*}{ Ungulate } & Axis deer & Axis Axis & Raw meat & Salmonella & $\begin{array}{l}\text { Salmonella } \\
\text { gastroenteritis }\end{array}$ & $\begin{array}{l}\text { Madar } \text { et al., } \\
2012\end{array}$ \\
\cline { 2 - 7 } & Wild boar & Sus scrofa & Raw meat & Trichinella & Trichinellosis & $\begin{array}{l}\text { Marva } \text { et al., } \\
2005\end{array}$ \\
\hline \multirow{5}{*}{ Diprotodontia } & Kangoroo & $\begin{array}{l}\text { Macropus } \\
\text { rufus, M. } \\
\text { Giganteus } \\
\text { and M. } \\
\text { Fuliginosus }\end{array}$ & Raw meat & Salmonella & Gastroenteritis & $\begin{array}{l}\text { Holds } \text { et al., } \\
2008\end{array}$ \\
\cline { 2 - 7 } & Kangoroo & $\begin{array}{l}\text { Macropus } \\
\text { rufus, M. } \\
\text { Giganteus } \\
\text { and M. } \\
\text { Fuliginosus }\end{array}$ & Raw meat & Escherichia coli & Gastroenteritis & $\begin{array}{l}\text { Holds } \text { et al., } \\
2008\end{array}$ \\
\hline
\end{tabular}

Zoonotic viruses present in bushmeat of species in Asia and Pacific

\begin{tabular}{|c|c|c|c|c|c|c|}
\hline Order & $\begin{array}{r}\text { Common } \\
\text { name }\end{array}$ & Species & $\begin{array}{l}\text { Part of the } \\
\text { animal }\end{array}$ & $\begin{array}{l}\text { Pathogen or Disease } \\
\text { agent }\end{array}$ & Disease & Reference \\
\hline Bird & $\begin{array}{l}\text { Crested } \\
\text { Hawk-Eagles }\end{array}$ & $\begin{array}{l}\text { Spizaetus } \\
\text { nipalensis }\end{array}$ & lungs & $\mathrm{A} / \mathrm{H} 5 \mathrm{~N} 1$ virus & Avian Influenza & $\begin{array}{l}\text { van Borm et al., } \\
2005\end{array}$ \\
\hline \multirow{2}{*}{ Rodent } & $\begin{array}{l}\text { Chinese } \\
\text { ferret-badger }\end{array}$ & $\begin{array}{l}\text { Melogale } \\
\text { moschata }\end{array}$ & $\begin{array}{l}\text { Nasal, fecal and } \\
\text { blood }\end{array}$ & SARS coronavirus & $\begin{array}{l}\text { Severe Acute } \\
\text { respiratory syndrom }\end{array}$ & Guan et al., 2003 \\
\hline & Chinese hare & Lepus sinensis & $\begin{array}{l}\text { Nasal, fecal and } \\
\text { blood }\end{array}$ & SARS coronavirus & $\begin{array}{l}\text { Severe Acute } \\
\text { respiratory syndrom }\end{array}$ & Guan et al., 2003 \\
\hline Ungulate & $\begin{array}{l}\text { Chinese } \\
\text { muntjac }\end{array}$ & $\begin{array}{l}\text { Muntiacus } \\
\text { reevesi }\end{array}$ & $\begin{array}{l}\text { Nasal, fecal and } \\
\text { blood }\end{array}$ & SARS coronavirus & $\begin{array}{l}\text { Severe Acute } \\
\text { respiratory syndrom }\end{array}$ & Guan et al., 2003 \\
\hline \multirow{2}{*}{ Carnivore } & Hog-badger & $\begin{array}{l}\text { Arctonyx } \\
\text { collaris }\end{array}$ & $\begin{array}{l}\text { Nasal, fecal and } \\
\text { blood }\end{array}$ & SARS coronavirus & $\begin{array}{l}\text { Severe Acute } \\
\text { respiratory syndrom }\end{array}$ & Guan et al., 2003 \\
\hline & $\begin{array}{l}\text { Himalayan } \\
\text { palm civet }\end{array}$ & P. larvata & $\begin{array}{l}\text { Nasal, fecal and } \\
\text { blood }\end{array}$ & SARS coronavirus & $\begin{array}{l}\text { Severe Acute } \\
\text { respiratory syndrom }\end{array}$ & Guan et al., 2003 \\
\hline \multirow{8}{*}{ Chiroptera } & $\begin{array}{l}\text { Horseshoe } \\
\text { bats }\end{array}$ & $\begin{array}{l}\text { Rhinolophus } \\
\text { pearsoni, }\end{array}$ & $\begin{array}{l}\text { Serum, fecal, } \\
\text { throat samples }\end{array}$ & SARS coronavirus & $\begin{array}{l}\text { Severe Acute } \\
\text { respiratory syndrom }\end{array}$ & Li et al., 2005 \\
\hline & $\begin{array}{l}\text { Horseshoe } \\
\text { bats }\end{array}$ & $\begin{array}{l}\text { Rhinolophus } \\
\text { pussilus }\end{array}$ & $\begin{array}{l}\text { Serum, fecal, } \\
\text { throat samples }\end{array}$ & SARS coronavirus & $\begin{array}{l}\text { Severe Acute } \\
\text { respiratory syndrom }\end{array}$ & Li et al., 2005 \\
\hline & $\begin{array}{l}\text { Horseshoe } \\
\text { bats }\end{array}$ & $\begin{array}{l}\text { Rhinolophus } \\
\text { macrotis }\end{array}$ & $\begin{array}{l}\text { Serum, fecal, } \\
\text { throat samples }\end{array}$ & SARS coronavirus & $\begin{array}{l}\text { Severe Acute } \\
\text { respiratory syndrom }\end{array}$ & Li et al., 2005 \\
\hline & $\begin{array}{l}\text { Horseshoe } \\
\text { bats }\end{array}$ & $\begin{array}{l}\text { Rhinolophus } \\
\text { sinicus }\end{array}$ & $\begin{array}{l}\text { Nasopharyngeal } \\
\text { and anal swabs } \\
\text { and blood samples }\end{array}$ & SARS coronavirus & $\begin{array}{l}\text { Severe Acute } \\
\text { respiratory syndrom }\end{array}$ & Lau et al., 2005 \\
\hline & $\begin{array}{l}\text { Horseshoe } \\
\text { bats }\end{array}$ & $\begin{array}{l}\text { Rhinolophus } \\
\text { sinicus }\end{array}$ & $\begin{array}{l}\text { Throat and faecal } \\
\text { swabs or fresh } \\
\text { faecal samples }\end{array}$ & SARS coronavirus & $\begin{array}{l}\text { Severe Acute } \\
\text { respiratory syndrom }\end{array}$ & Ge et al., 2013 \\
\hline & Bats & Roussetus spp. & Blood samples & $\begin{array}{l}\text { Ebola Zaire and } \\
\text { Reston viruses }\end{array}$ & $\begin{array}{l}\text { Ebola hemorrhagic } \\
\text { fever }\end{array}$ & Olival et al., 2013 \\
\hline & $\begin{array}{l}\text { Island flying } \\
\text { fox }\end{array}$ & $\begin{array}{l}\text { Pteropus } \\
\text { hypomelanus }\end{array}$ & Urine & Nipah virus & $\begin{array}{l}\text { Encephalitis and } \\
\text { respiratory disease }\end{array}$ & Chua et al., 2003 \\
\hline & $\begin{array}{l}\text { Large flying } \\
\text { fox }\end{array}$ & $\begin{array}{l}\text { Pteropus } \\
\text { vampyrus }\end{array}$ & Urine & Nipah virus & $\begin{array}{l}\text { Encephalitis and } \\
\text { respiratory disease }\end{array}$ & Chua et al., 2003 \\
\hline
\end{tabular}

